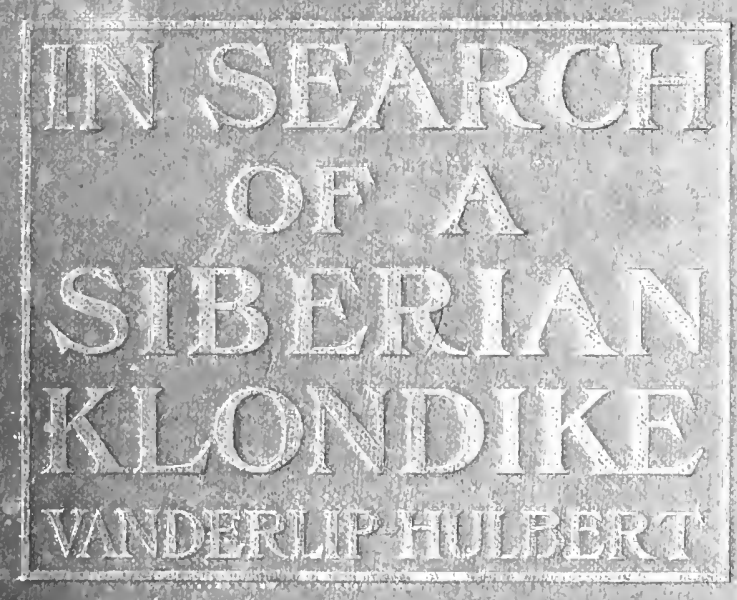

fornia

nal

ty
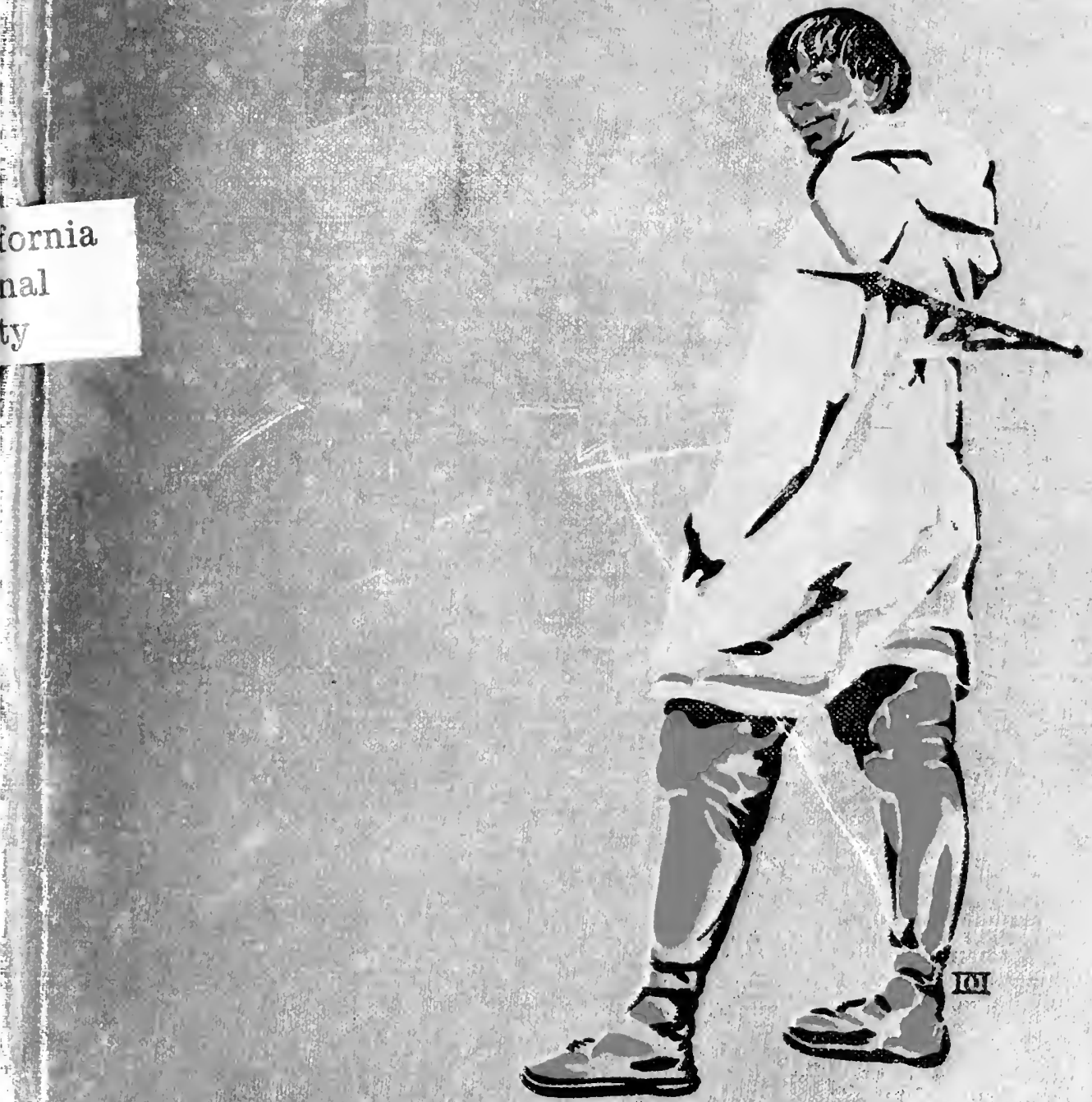

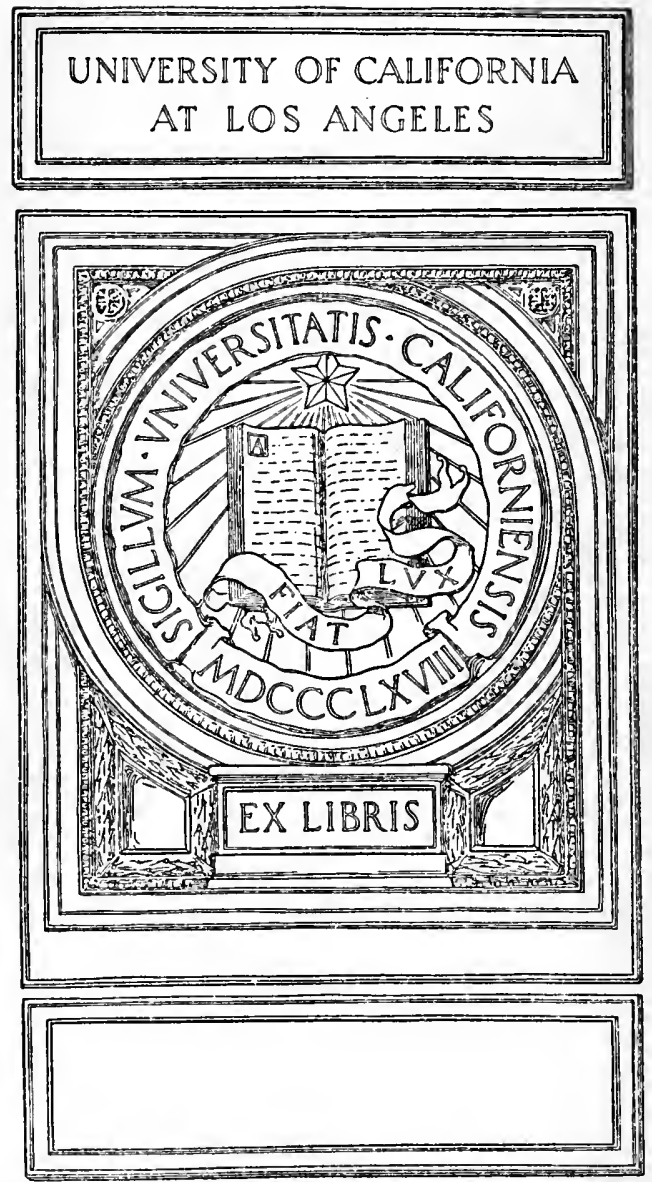
Digitized by the Internet Archive in 2008 with funding from Microsoft Corporation 


\section{,}




\title{
IN SEARCH OF A SIBERIAN KLONDIKE
}

\author{
AS NARRATED BY \\ WASHINGTON B. VANDERLIP \\ THE CHIEF ACTOR \\ AND \\ HEREIN SET FORTH BY \\ HOMER B. HULBERT
}

ILLUSTRATED WITH

MANY PHOTOGRAPHS

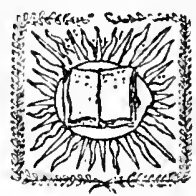

NEW YORK

THE CEN'TURY CO.

1903 
Copyright, 1903, by

The Century Co.

Published, October, 1903

THE DE VINNE PRESS 


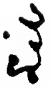

y

1 ले
TO

“THE LITTLE MOTHER"

\{

$2+309$ 


\section{CONTENTS}

CHAPTER

I. OUTFIT AND SUPPLIES

Rumor of gold in northeastern Asia-Plan to prospect through Kamchatka and north to Bering StraitSteamer Cosmopolite-Russian law in the matter of liquor traffic-I make up my party and buy suppliesKorean habits of dress-Linguistic difficulties . . . .

II. SAGHALIEN AND THE CONVICT STATION AT KORSAKOVSK

Departure of the expedition-Arrival at KorsakovskCondition of convict station-Freedom allowed prisoners, most of whom are murderers-Wreck of the steamer and loss of outfit-Gold lace and life-preservers-Return to Korsakovsk-Russian table manners - The Russian's naïve attitude toward bathing-Some results of the intermarriage of criminals-How Yankee shrewdness saved some confiscated photographs-Pleasant sensations on being shaved by a murderer-Predominance of American goods . . . . . . . .

III. PETROPAULOVSK AND SOUTHERN KAMCHATKA

Volcanoes of Kamchatka and the superstitious natives - The first prospecting trip-Copper found, but no gold-Mosquitos cause an evacuation of the land-The typical Chinese peddler. . . . . . . . . .

\section{SALMON-FISHING IN THE FAR NOR'TH}

Tide that rises twenty-five feet-Wholesale suicide of salmon-Fish-eyes as a delicacy for sea-gulls-How 
the natives store fish for the sledge-dogs-The three varieties of salmon-An Arcadian land for the birds .

v. THE TOWN OF GHIJIGA

The sacred icon and the sewing-machine both in evidence-The native "process of getting married"-Mrs. Braggin's piano-American pack-saddles and Russian obstinacy-Theodosia Chrisoffsky and his sixty descendants. . . . . . . . . . . . . .

VI. OFF FOR THE TUNDRA-A NATIVE FAMILY Hard traveling - The native women $-A$ mongrel raceChrisoffsky's home and family and their ideas of domestic economy-Boiled fish-eyes a native delicacyProspecting along the Ghijiga . . . . . . . .

\section{TUNGUSE AND KORAK HOSPITALITY}

My Korak host-"Bear !"-I shoot my first arctic fox - My Tunguse guide-Twenty-two persons sleep in a twelve-foot tent-Tunguse family prayers-The advent of Howka-Chrisoffsky once more . . . . . . .

VIII. DOG-SLEDGING AND THE FUR TRADE

Description of the sledge and its seven pairs of dogsThe harness-The useful polka-The start-off a gymnastic performance for the driver-Methods of steering and avoiding obstructions while going at full speedDog-trading en route-Dog-fights are plentiful-Prices of sable and other skins in the native market-The four grades of sables-How they live and what they live on -A Russian writer on sable hunting-Days when a native would barter eighteen sable skins for an ax . .

\section{OFF FOR THE NORTH-A RUNAWAY}

My winter wardrobe of deerskin-Shoes that keep the feet warm when it is sixty degrees below zero-Plemania, a curious native food in tabloid form-Other provisions-Outline of proposed exploration about the 
sources of the Ghijiga River-Four hours of sun a day -When dog meets deer-A race for life and a ludierous dénouement-More queer native dishes-Curious habits of the sledge-dog . . . . . . . . . . . . 139

\section{THROUGH THE DRIFTS}

Sledging over snow four feet deep-Making a camp in the snow - Finding traces of gold $-A$ grand slide down a snow-covered hill-My polka breaks with disastrous results-Prospecting over the Stanovoi range . . . .

\section{BURIED IN A BIIZZARD}

A trip to the northern side of the Stanovoi range of mountains-Nijni Kolymsk, the most-feared convict station-Sledging by light of the aurora-Lost in a blizzard on the vast tundra-Five days in a snow dugout-I earn a reputation as a wizard-Back at Chrisoffsky's . . . . . . . . . . . . . . . .

\section{CHRISTMAS-THE "DEER KORAKS"}

I celebrate Christmas day with the over-kind assistance of two lundred natives-Koraks as sharp-shootersComic features of a Russian dance-Off for Kaminaw -Another runaway-Slaughtering deer $-\Lambda$ curious provision of nature-Eight families in one yourtaKorak method of washing dishes $-A$ herd of ten thousand deer . . . . . . . . . . . . . .

\section{HABITS AND CUSTOMS OF THE KORAKS}

The hour-glass houses-Their curious eonstructionThe natives prove to be both hospitable and filthyDialects of Dog Koraks and Deer Koraks-Some unplcasant habits-How they reckon time-Making liquor out of mushrooms-Curious marriage customs-Clothes of the natives-Queer notions of a deity - Jealousy of the wandering Koraks-Thieving a virtue and childbirth a social function . . . . . . . . . . . 205 
CHAPTER

XIV. OFF FOR BERING SEA-THE TCHUKTCHES The Tchuktches are the Apaches of Siberia-Their hospitality to Americans and their hostility to RussiansWherein $\mathrm{my}$ experiences differ from those of Mr. Harry DeWindt-Result of licking a piece of stone with the thermometer at 450 below zero-KoniklyPower of moral suasion in dealing with a rebellious Korak-The cure of a dying woman and the disgust of her husband-Poll-tax and the Tchuktches . . . .

XV. A PERILOLS SUMMER TRIP

The tundra in summer-Crossing the swift Paran River - Literally billions of mosquitos-Unique measures of protection against these pests-Mad race down the Uchingay River on a raft-Lighting a fire with a pistol - Narrow escape from drowning-Fronyo proves to be a man of mettle-Pak is caught stealing from slim supply of provisions and receires chastisement-Subsisting on wild onions and half-ripe berries-Help at last .

XVI. A TEN-THOLSAND-MILE RACE

Persistent rumors of gold in the Tchuktche peninsula - Count Unarliarsky-I am called to Vladirostok to fit out an expedition-Our ressel arrires off Indian Point-Charging through the ice-floes $-A$ meeting with Eskimos-Our prospecting prores fruitless-We meet the rival expedition in Plover Bay-Their chagrinThe end . . . . . . . . . . . . . 


\section{LIST OF ILLUSTRATIONS}

Washington B. Vanderlip . . . . . Frontispiece

Map showing the territory covered by Mr. Vanderlip in his search for a Siberian Klondike . . .

Korean Miners . . . . . . . . . . . 15

Market-place, Korsakorsk, Saghalien Island . . $\quad 25$

Russian Murderers in Angle of Prison-House, Korsakovsk, Saghalien Island . . . . . . 37

Main Street of Petropaulovsk, Kamchatka . . . 45

A River of Dead Salmon-August . . . . . 53

The Salmon Catch . . . . . . . . . . 57

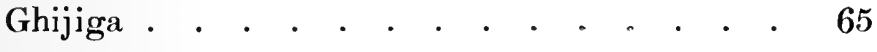

Russian Church, Ghijiga . . . . . . . . 71 


\section{xii LIST OF ILLUSTRATIONS}

House in Ghijiga occupied by Mr. Vanderlip and his Party

House of Theodosia Chrisoffsky, Christowic . . 81

Start from Ghijiga, Summer-time. Theodosia Chrisoffsky and Family-Fourteen Children . 87

Village of Christowic, Okhotsk Sea . . . . . 93

Mr. Vanderlip on "Bill" . . . . . . . . 99

The Pride of the Family . . . . . . . . 105

Mr. Vanderlip crossing Turumcha River . . . 111

Sledge-dogs, showing Harness and Method of Hitching

Mr. Vanderlip's Dog-sled loaded . . . . . . 125

Ghijiga River in Winter . • . . . . . 129

Deer crossing River . . . . . . . . . . 141

Reindeer . . . . . . . . . . . . . 145

Theodosia Chrisoff sky, Guide . . . . . . . 151

Mr. Vanderlip and Reindeer Team . . . . . 157

Native Winter Camp . . . . . . . . . 163

Mr. Vanderlip on March with Deer Outfit . . . 173 


\section{LIST OF ILLUS'TRATIONS xiii}

Reindeer

Herd of Reindeer

:

Reindeer, Herders in background . . . . . 195

Reindeer-Summer . . . . . . . . . . 201

Upper View of Underground Hut-Home of the Dog Korak . . . . . . . . . . . . 207

Chinese Punp . . . . . . . . . . . . 213

One of the Tcluktches-an unconquered Race . 227

Summit of Kamchatka-First Sight of Bering Sea

233

Kassegan, half-caste Russian trader, and Korak wife, living at Boeta, Baron Koff Bay, Kamchatka

In Crater of Extinct Volcano, digging for Sulphur. Baron Koff Bay, Kamchatka . . . . 245

Killing Deer for Dog-food . . . . . . . . 251

Expedition on march_- Konikly" in foreground 257 Across the Tundra . . . . . . . . 261 Tundra Camp . . . . . . . . . . . . 267 


\section{xiv LIST OF ILLUSTRATIONS}

"Kim" in Summer Camp on Tundra . . . . 273

Reindeer Feeding . • . . . . . . . . $\quad$. 279

Three Little Half-caste Russians and Native Nurse, Ghijiga, Okhotsk Sea . . . . . 287

Russian Miners . . . . . . . . . . 293

Picked up on the Ice off St. Lawrence Island . $\quad 299$

Natives at Indian Point, Siberia . . . . 303

Eskimo Village, East Cape-Northeastern Point of Asia . . . . . . . . . . . . 307

Plover Bay, Siberia, in July . . . . . . 313 


\section{PREFACE}

The following pages are the result of one of those delightful partnerships in which the party of the first part had all the adventures, pleasant and otherwise, while the party of the second part had only to listen to their recital and put them down on paper. The next best thing to seeing these things for one's self is to hear of them from the lips of such a delightful raconteur as Mr. Vanderlip. Whatever defects may be found in these pages must be laid at the door of the scribe; but whatever is entertaining and instructive is due to the keen observation, the retentive memory, and the descriptive powers of the main actor in the scenes herein depicted.

H. B. H.

Seoul, Korea, December, 1902. 
IN SEARCH OF A SIBERIAN KLONDIKE 


\section{IN SEARCH OF A SIBERIAN KLONDIKE}

\section{CHAP'TER I}

\section{OUTFIT AND SUPPLIES}

Rumor of gold in northeastern Asia-Plan to prospect through Kamchatka and north to Bering StraitSteamer Cosmopolite-Russian law in the matter of liquor traffic-I make up my party and buy suppliesKorean habits of dress-Linguistic difficulties.

WHEN the rich deposits of gold were found on the Yukon River, and later in the beach sands of Cape Nome, the question naturally arose as to how far these deposits extended. Sensational reports in the papers, and the stories of valuable nuggets being picked up along the adjacent coast of Asia, fired the imagination of the Russians, who hoped, and perhaps not without reason, to repeat the marvelous successes which had been met with on the American side. The existence of valuable gold deposits in other parts of Siberia lent color to the belief that the goldbearing belt extended across from America to Si- 
beria, and that consequently the Asiatic shores of Bering Sea ought to be well worth prospecting.

No people were ever more alive to the value of mineral deposits than the Russians, and none of them have been keener in the search for gold. As evidence of this we have but to point to the vast, inhospitable wilderness of northern Siberia, where gold has been exploited in widely separated districts and under conditions far more trying than those which have surrounded any similar undertaking, with the exception of the Klondike.

I had left Chittabalbie, the headquarters of the Oriental Consolidated Mining Company,-an American firm that is successfully exploiting the gold deposits of northern Korea,-and being enamoured of a wandering life, I found myself one morning entering the magnificent harbor of Vladivostok, the eastern terminus of the Siberian Railway and the principal Russian distributing center on the Pacific coast.

I believed that as the northeastern extremity of Asia was as yet virgin ground to the prospector, there would be no better opportunity for the practice of my profession than could be found in the town of Vladivostok. The surmise proved correct, and I was almost immediately engaged by a Russian firm to make an extended prospecting tour in Kamchatka, through the territory north of the Okhotsk Sea and along the shores of 


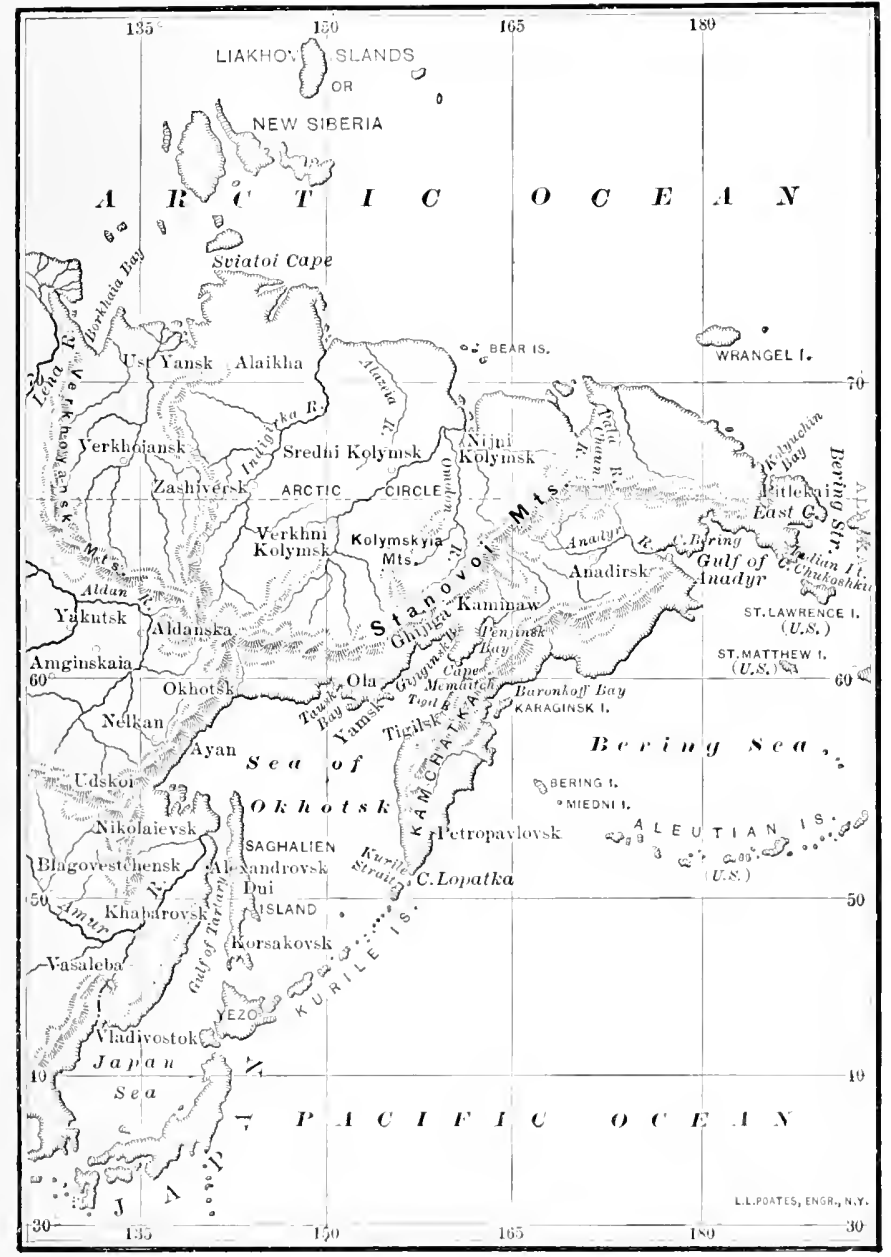

Map showing the territory covered hy Mr. Vanderlip in his seareh for a siberian Klondike. 

Bering Sea. 'This arrangement was made with the full cognizance and approval of the Russian authorities. I carried a United States passport. The Russians gave me another at Vladivostok, and through the Governor-general at that place I secured an open letter to all Russian magistrates in eastern Siberia, instructing them to give me whatever help I might need in the procuring of food, sledge-dogs, reindeer, guides, or anything else that I might require. Not only were no obstacles put in my way, but I was treated with the utmost courtesy by these officials, who seemed to realize the possible value of the undertaking.

My instructions were to go first to the town of Petropaulovsk, on the southern point of the peninsula of Kamchatka, and explore the surrounding country for copper. The natives had brought in samples of copper ore, and it was also to be found in the beach sands near Petropaulovsk, as well as in a neighboring island, called Copper Island, where the Russians had opened up a mine some seventy years before, but without success. I was next to go north to Baron Koff Bay, on the eastern coast of the peninsula, near its neck, and examine some sulphur deposits which were supposed to exist in that vicinity and which the government was very desirous of working. From that point $I$ was to cross the neck of the peninsula by reindeer sledge to the head of 
the eastern branch of the Okhotsk Sea, my objective point being Cape Memaitch, where I was to prospect for gold. It had been reported that on two successive years an American schooner had touched at this point and carried away full cargoes of gold ore to San Francisco. I was then to pass around the head of the Okhotsk Sea to the important trading town of Ghijiga. This was the headquarters, some thirty years ago, of the Russo-American Telegraph Company, with which Mr. George Kennan was connected and where he spent one winter.

Making this my headquarters, I was to work out in various directions in search of the yellow metal, and finally I was to use my own judgment as to whether I should strike northeast to Bering Strait, following the Stenova range of mountains, or southward to Ola, where a steamship could stop and take me off the following summer. As we shall see, the main points of this plan were carried out, though not in the order here given.

As to the means for reaching Kamchatka I had no choice. There is no royal mail steamship route to these boreal regions. A "tramp" steamship is anmually chartered by the great firm of Kunst and Albers in Vladivostok, and rechartered by them to the Russian government, to take the Governor-general on his annual visit to 
Saghalien and the trading posts in Kamchatka, and even as far northward as Anadyr, situated inland from Bering Sea on the Anadyr River. At each of these trading posts is a Russian magistrate, or nitcheilnik, and a guard of about twenty Cossacks. The annual steamer carries the supplies for these officials and for the traders, as well as the goods which are used in trade. On her return, the steamer brings back the furs of the Russian Chartered Company, who hold all the furring rights of northeastern Siberia.

In the summer of 1898 the steamer Cosmopolite was scheduled to make the annual voyage. She was a German tramp steamer of one thousand tons. Besides the captain there was but one other foreign officer. The crew was Chinese. In addition to the annual mails she carried a full cargo of tea,flour, sugar, tobacco, and the thousand and one articles that make the stock in trade of the agents of the Chartered Company. She was allowed to carry no wines or liquors, with the exception of sixty bottles of vodka for each trader, and that for his private use only. He is strictly forbidden to sell a drop to the natives. For a first offense he is heavily fined, and for a second he serves a term of penal servitude on the island of Saghalien. This law is in brilliant contrast to the methods of other governments in respect to liquors. Africa and the Pacific Islands bear wit- 
ness to the fact that, from the standpoint both of humanity and mere commercial caution, the Russian government is immeasurably ahead of other powers in this respect. The sale of intoxicants demoralizes the natives and "kills the goose that lays the golden egg." Of course there is an occasional evasion of the law. The natives of Siberia are passionately fond of spirits of any kind, and, having tasted a single glass, will sell anything they have-even their wives and daughters-for another. When they are in liquor a single wineglass of vodka will induce them to part with furs which in the London market would bring ten pounds. Besides this annual steamship, two Russian men-of-war cruise north along the coast, looking for American whalers who bring alcoholic liquors to exchange for skins.

I decided to take with me two Koreans from Vladivostok. They were gold-miners from southern Siberia. Being expert horse-packers and woodsmen and speaking a little Russian, they were sure to be of great use to me. They were named Kim and Pak respectively; both are among the commonest family. names in Korea, the Kim family having originated at least as early as 57 в. c. Kim was thirty years old and was possessed of a splendid physique. He could take up four hundred pounds of goods and carry them a quarter of a mile without resting. Koreans are 
taught from childhood to carry heavy weights on their backs. They use a chair-like frame, called a $j i g i$, which distributes the weight evenly over the shoulders and hips and enables them to carry the maximum load with the minimum of fatigue. Kim was always good-natured even under the most discouraging circumstances, and he was fairly honest. Pak was thirty-eight, tall and thin, but enormously strong. He enjoyed the possession of only one eye, for which reason I promptly dubbed him " Dick Deadeye." He was a cautious individual, and always " packed" his money in his clothes, sewed up between the various thicknesses of cloth; and whenever he had a bill to pay and could not avoid payment, he would retire to a secluded place, rip himself open, and return with the money in his hand and a mysterious look on his face, as if he had picked the money off the bushes.

Having secured the services of this precious pair, I promptly marched them off to the store of one Enoch Emory to exchange their loose Korean clothes for something more suited to the work in hand. This Enoch Emory, by the way, is a character unique in Siberian history. When sixteen years old he came out from New England as cabin-boy on a sailing vessel which had been sent by an American company to establish trading stations on the Amur. He left the vessel and 
went into one of the company's stores. He now " owns" the company and is one of the wealthiest merchants in Siberia. The company operates immense stores in Nikolaievsk, Blagovestchensk, and Khabarovka, with a large receiving store at Vladivostok. Emory always favors American goods and sells immense numbers of agricultural implements and of other things in the manufacture of which America excels. This is the only great American firm in Siberia. Emory makes his home in Moscow and comes out once a year to inspect his stores. He is a typical Yankee of the David Harum stamp.

When my two protégés came to change Korean dress for American it was difficult to decide just where the dress left off and the man began. The Korean bathing habits are like those of the medieval anchorite, and an undergarment, once donned, is lost to memory. Besides the two Koreans, I engaged the services of a Russian secretary named Nicolai Andrev. He was an old man and not by any means satisfactory, but he was the only one I could get who knew the Russian mining laws and who could make out the necessary papers, in case I should have occasion to stake out claims. As it turned out, he hampered the movements of the party at every turn; he could not stand the hard knocks of the journey, and I was obliged to drop him later at the town of Ghijiga. 
His lack of teeth rendered his pronunciation of Russian so peculiar that he was no help to me in acquiring the language, which is not easy to learn even under the best of circumstances. I was also accompanied by a young Russian naturalist named Alexander Michaelovitch Yankoffsky. As this name was quite too complicated for everyday use, I had my choice of paring it down to "Alek," "Mike," or "Yank," and while my loyalty to Uncle Sam would naturally prompt me to use the last of these $I$ forbore and Alek he became. He did not take kindly to it at first, for it is de rigueur to address a Russian by both his first and second names, the latter being his father's name with vitch attached. This was out of the question, however, and he succumbed to the inevitable.

So our complete party consisted of five men, representing three languages. None of my men knew any English, and I knew neither Russian nor Korean, beyond a few words and phrases. But before two months had elapsed, I had, by the aid of a pocket dictionary, my little stock of Korean words, and a liberal use of pencil and paper, evolved a triglot jargon of English, Korean, and Russian that would have tried the patience of the most charitable philologist.

The steamer was to sail in eight days, and this necessitated quick work in making up my outfit. 
For guns I picked a twelve-bore German fowling-piece with a rifle-barrel beneath, in order to be equipped for either small or large game without being under the necessity of carrying two guns at once; a Winchester repeating rifle, 45-90; an .88 Mannlicher repeating rifle; and two 45caliber Colt revolvers. As money is little used among the natives of the far North, it was necessary to lay in a stock of goods to use in trade. For this purpose I secured one thousand pounds of Moharka tobacco. It is put up in four-ounce packages and costs fifteen rouble cents a pound. I procured also two thousand pounds of sugar both for personal use and for trade. This comes in solid loaves of forty pounds each. Next in order came two thousand pounds of brick-tea. Each brick contains three pounds, and in Hankau, where it is put up, it costs twelve and a half cents a brick. It is made of the coarsest of the tea leaves, twigs, dust, dirt, and sweepings, and is the kind universally used by the Russian peasantry. I also secured one hundred pounds of beads, assorted colors, and a goodly stock of needles, together with ten pounds of colored sewing-silks which the natives use to embroider the tops of their boots and the edges of their fur coats. Then came a lot of pipe-bowls at a cent apiece, assorted " jewelly," silver and brass rings, silk handkerchiefs, powder and shot, and 44-caliber 


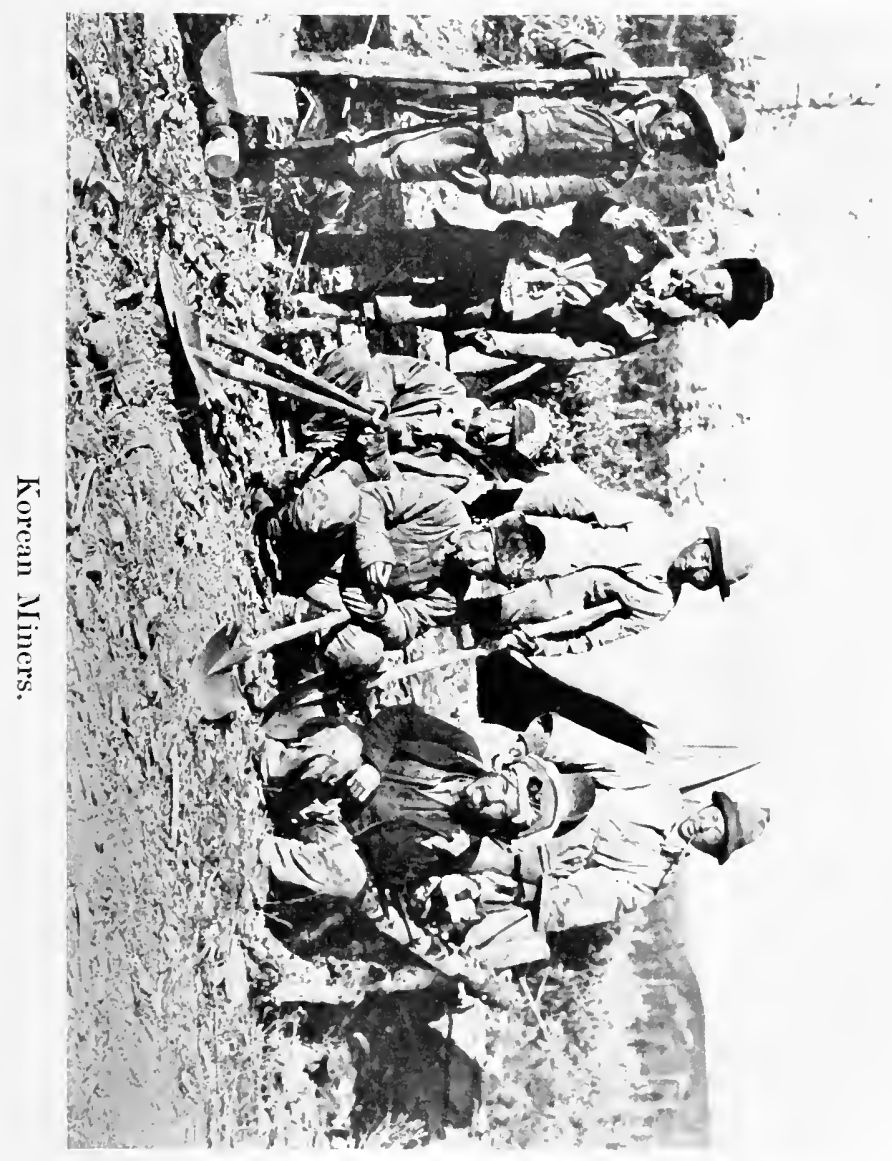



cartridges. The last mentioned would be useful in dealing with the natives near the coast, who commonly use Winchester rifles. Those further inland use the old-fashioned musket exclusively.

For my own use I laid in a goodly supply of Armour's canned beef,canned fruits, dried fruits, lime-juice, bacon, three thousand pounds of beans, canned tomatoes, tinned butter, coffee, German beef-tea put up in capsules an inch long by half an inch thick (which proved extremely fine), and canned French soups and conserves. Besides these things, and more important than all, I took two tons of black bread-the ordinary hard rye bread of Russia, that requires the use of a prospecting hammer or the butt of a revolver to break it up. This was necessary for barter as well as for personal use.

Judging from my experiences in Australia, Burma, Siam, and Korea, as well as from my reading of Nansen, I thought it best not to encumber myself with any liquors excepting four bottles of brandy, which were carried in the medicine-chest and used for medicinal purposes only. My medical outfit consisted of four main articles, quinine, morphine, iodoform, and cathartic pills. With these four one can cope with almost anything that is likely to happen. The chest contained also bandages, absorbent cotton, mustard 
leaves, a hot-water bottle, two small surgeon's knives, and a pair of surgical scissors.

After a prolonged search for really good packsaddles, I concluded that such things were unknown in Siberia; so, calling in a Chinese carpenter, I gave him a model of an Arizona pack-saddle, with instructions to turn out a dozen at the shortest possible notice. I proposed to teach my Koreans how to throw the "diamond hitch," but I found later, to my humiliation, that what the Korean does not know about packing is not worth knowing. Either Kim or Pak could do it quicker and better than I. Two thousand years of this sort of thing have left little for the Korean to learn.

Mining-tools were of course a necessity. Even in Vladivostok I could not secure what I wanted. I therefore took what I could get. I purchased drills, hammers, a crow-bar, a German pump which was guaranteed to pump sand (but which I found later would pump nothing thicker than pure water), a quantity of blasting powder called " rack-a-rock," picks, shovels, wire, nails, and other sundries. The Russian shovel is an instrument of torture, being merely a flat sheet of iron with a shank for the insertion of a handle, which latter is supposed to be made and fitted on the spot. As there is no bend at the neck of the shovel, the lack of leverage makes it a most unwieldy and exasperating utensil. As for the Rus- 
sian pick, it has but one point, and in its construction is clumsy beyond belief. Even the Korean picks are better. I also carried a simple blowpipe outfit, an aneroid, a compass, gold-screens, and gold-pans, with other necessary appliances for prospecting. These preparations were made very hurriedly, as the Cosmopolite was the only steamer going north during the season.

Tourists sometimes ask if it would not be possible to secure passage on this annual steamer and take the trip along the coast to Bering Sea and back. There is nothing to prevent it. The trip of three months, stopping at ten or twelve points along the coast, could be made for about three hundred roubles, a rouble representing fifty cents in gold. But the trip would be of little value or interest, because, in the first place, the natives bring down their furs to the trading stations during the winter, when the ice makes traveling possible, so that one would have very little opportunity of seeing anything of native life, or of securing any of the valuable furs that come out of this region each year. It would be impossible for the tourist to pick up any good ones in summer. Outside of natives and furs, it is difficult to see what interest there could be in such a trip, unless the tourist is studying the habits of mosquitos and midges, in which case he would strike a veritable paradise. 


\section{CHAPTER II}

\section{SAGHALIEN AND THE CONVICT STATION AT KORSAKOVSK}

Departure of the expedition-Arrival at Korsakovsk-Condition of convict station-Freedom allowed prisoners, most of whom are murderers-Wreck of the steamer and loss of outfit-Gold lace and life-preservers-Return to Korsakovsk - Russian table manners-The Russian's naïve attitude toward bathing-Some results of the intermarriage of criminals-How Yankee shrewdness saved some confiscaicd photographs-Pleasant sensations on being shaved by a murderer-Predominance of American goods.

$A^{T}$ six o'clock in the afternoon of July 22, A 1898, the Governor-general with his wife and suite, resplendent in gold lace and buttons, came aboard in the rain. The anchor was heaved up and we pointed southward toward the open sea, which is reached by way of a passage from half a mile to three miles wide and twelve miles long. The shore on either side bristles with armaments which, together with the narrowness of the passage, make Vladivostok entirely impregnable from the sea.

There is a story, however, which the Russians 
never like to hear. One morning, after a night of dense fog, as the sun cleared away the mist, four big British men-of-war were found anchored within two hundred yards of the city, and could have blown it skyward without a shot from the batteries, being safe from the line of fire. Since then big guns have been mounted to cover the inner harbor. Reaching open water, we turned to the northeast and set our course toward the southern point of the island of Saghalien, for the Governor-general was to inspect the convict station of Korsakovsk.

Three days of uneventful steaming at ten knots an hour brought the shores of Saghalien above the horizon. We saw a long, curved beach backed by low-lying hills covered with fields and woodland. As the place could boast no harbor, we dropped anchor in the open roadstead a mile from shore. Our whistle had long since waked to life an asthmatic little steam-launch, which soon came alongside. We forthwith invaded her stuffy little cabin and she waddled shoreward.

As we approached the rough stone quay, we had our first glimpse of Russian convict life. A gang of prisoners were at work mending the seawall. Some of them wore heavy iron balls at their ankles, which they had to lift and carry as they walked, else they dragged ponderously along the ground. These balls would weigh about a hun- 
dred pounds apiece. The convicts seemed to be well fed, but were excessively dirty and unkempt. They appeared to be men of the very lowest grade of mental development. It must be remembered that no political convicts are confined on the island of Saghalien. They are kept in the far interior of Siberia, where the chances of escape are much less, and where there is no possibility of contact with others than their own jailers. The convicts on Saghalien are almost all desperate criminals. As there is no such thing as capital punishment in Siberia, Saghalien is the terrestrial Valhalla of these doomed men, a sort of ante-mortem purgatory.

We stepped out upon the quay and walked up into the town. The street was about fifty feet wide, with a neat plank walk on either side. The houses were all log structures, but not the kind we are accustomed to associate with that name. The Russian makes the best log house in the world. The logs are squared and carefully fitted together. The windows are mostly double, and the houses, all of one story, are warm enough to be habitable. The streets are lined with small shops and stores. The entire population outside of the officials consists of convicts, most of whom enjoy almost complete freedom within the limits of the town. It gives one a queer feeling to walk through the streets of a town and know that all 
the storekeepers, carpenters, blacksmiths, clerks, butchers, and bakers are or have been desperate criminals. This town of Korsakovsk contains about two thousand people, of whom nine tenths are convicts.

$I$ asked if I might inspect the prison, expecting a prompt refusal, and was surprised when informed that I could go wherever I pleased. Approaching the main entrance to the prison, I found the two heavy gates off their hinges and the convicts coming and going at their own pleasure. A sleepy Cossack was on guard, and he did not even challenge me. 'The prison buildings were arranged around a large quadrangle. The prisoners were talking, lying about at their ease, with a few at work on little wood carvings.

I was astonished to see no prison bars anywhere, but after I had looked about at my leisure, one of the officers took me in charge and led me into another part of the grounds, where we found a sentry on guard, armed only with a revolver. This guard took us in hand and conducted us to a small building which appeared to be heavily barred. Inside were rows of clean, dry, whitewashed cells, half a dozen of which were occupied by convicts who had recently committed murder on the island, and were about to be sent north to the dreaded coal-mines, where they would be chained to wheelbarrows. 'These would be their 
constant companions for seven years, night and day, summer and winter.

In the workshops the convicts seemed to be trying to do as little as possible. They were making tools, hinges, horse-shoes, farming-implements, and other simple ironwork. In another portion of the shops they were making wagons and carts. Very many of the convicts are farmers, and they seemed to be cultivating the surrounding fields with success. In the main offices I found a dozen clerks smoking and drinking tea. They were all convicts, most of them having dark crimes to their discredit.

Leaving the prison, we walked down the street and soon came to a little stand, where bread and milk were being sold by a nice-looking Russian girl. I asked on what charge she had been brought to Saghalien. The officer interpreted my question. The girl laughed and said that she had murdered her husband. She was twenty-three years old.

We had arrived at ten in the morning, and, as we left at four in the afternoon, my inspection of the town was necessarily brief, but enough had been seen to give impetus to even a very ordinary imagination.

When we had all embarked again and the bell in the engine-room gave the signal for starting, we were enveloped in a thick mist; but as we had 


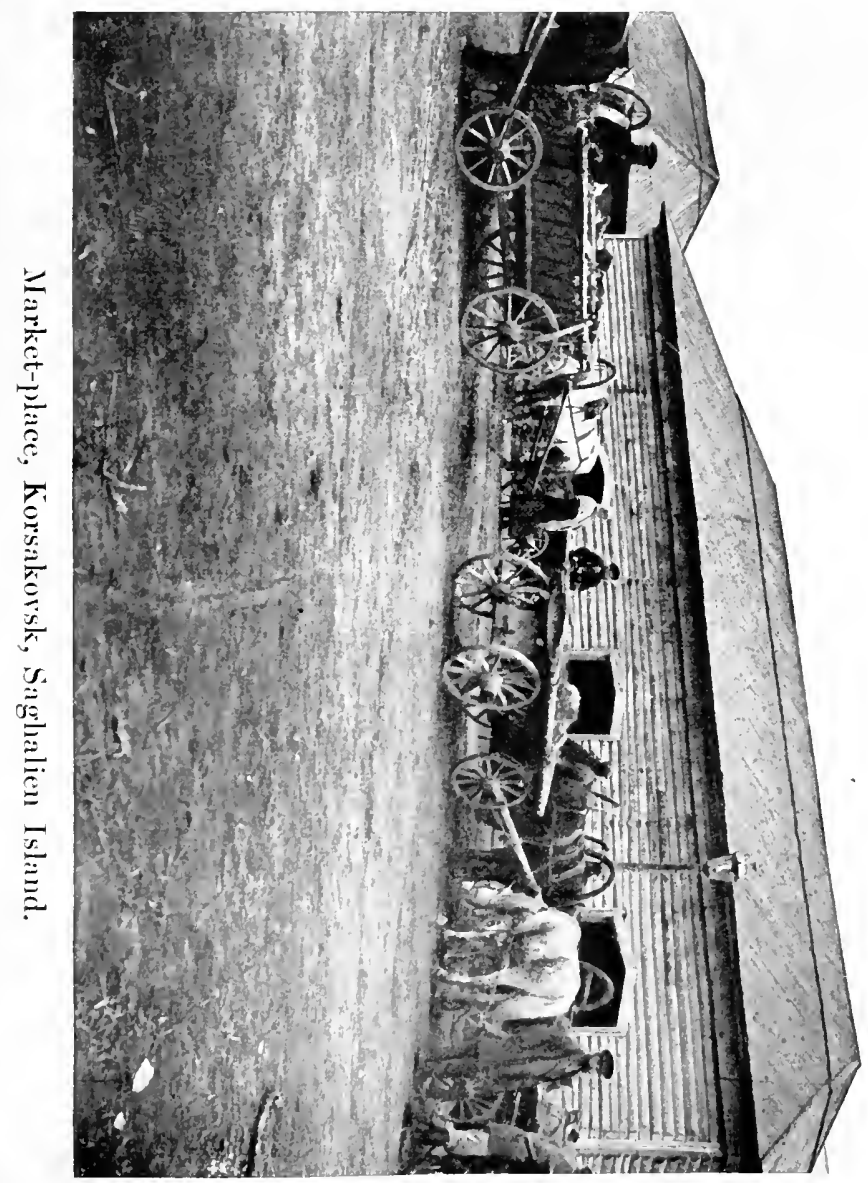



open sea before us and nothing, apparently, to fear, we drove ahead at full speed through the dense fog, pointing southeast in order to round the southern point of the island and make our way up the eastern coast. We might have been more cautious had not the Governor-general been in haste. As it turned out, we would have done better to proceed more slowly; for shortly after eight o'clock, as I. was sitting at dinner with the captain and the first officer, we heard the second mate on the bridge call loudly: "Hard aport! Ice ahead!" The captain rushed to the bridge, and I made my way to the prow of the boat. Peering through the fog in the failing light, I descried a low, white line that looked like ice, behind which a great dark mass rose high in the air. We had not begun to slow down yet, and almost instantly we struck with terrific force, which threw me to my knees. I scrambled to my feet and peered over the rail. I saw that the white line was not ice, but surf, and the dark object behind it was a cliff which towered hundreds of feet in the air.

The utmost confusion prevailed among the Chinese crew and the Korean stevedores. It looked as if there would be serious trouble. I made my way as rapidly as possible to my stateroom and buckled on my revolvers, tore my valise open and stuffed a package of money into my 
pocket, and hurried on deck to help put down any rush that the Asiatics might make for the boats. The first officer was sounding the forward well, and water was already coming into the engineroom. 'The steamer, evidently, was making water very fast. As there were so few foreign officers, and as the Russians were of no use, the captain ordered me to get out the boats. Amid such confusion this was no easy task, but by means of the most sanguinary threats and the show of my revolver, I got enough men together to swing a boat over the side.

Fortunately, there was no sea running at the time, and affairs began to assume a more hopeful aspect when it was found that we lay on a shelving beach and could not sink. We hurriedly supplied the boats with casks of water and bags of biscuits; but as there was no immediate danger of sinking, the captain asked me to take one of the boats and explore the shore for a suitable landingplace. With a strong headlight in the prow, we pushed off in the fog; and within an hour we were back with the news that half a mile up the shore there was a good landing-place. The Governorgeneral and his wife and staff were, of course, the first to be sent ashore. 'The lady seemed to take it very coolly, even more so than some of the staff. The latter, as soon as the alarm sounded, had hastened to their state-rooms and put on their swell- 
est regimentals. Their gold lace, glittering swords, and patent-leather boots seemed curiously out of place on board the wreck. It reminded me of the ancient Persian custom of going into battle in full regalia. These Russians left everything but their fine clothes.

In due time they were landed, and then we came back and took off the crew. It was growing light and the sea was rising. The steamer began to pound on the reef, and it was evident that she would not hold together long. The captain said he was going to stay on her till she broke up. As I was an enthusiastic knight of the camera, I thought this would be a good opportunity to secure a picture of a ship going to pieces, so I determined to stay with the captain as long as possible. We remained on board all that day and the next two, taking watch, by turns, six hours at a time. We determined to rig a block and tackle over the after hatch, and although this was under water, we managed to get hold of the big Russian mailbags and haul them out. Among other things, they held fifteen thousand roubles in notes.

During the second day of our detention we sighted the British gunboat Archer passing us to the southeast on her way to Kamchatka. We tried desperately to attract her attention with bombs, but did not succeed. Meanwhile, the chief officer had taken the long-boat and part of the 
crew and sailed back to Korsakovsk with a fair wind, to secure help. Three days later, he returned with the steam-launch and two lighters, one of which was filled with convicts who had been brought to help in getting the steamer off the rocks, if possible. If not, they were to save what cargo they could. They were put into the forward hold and a few cases were gotten out, but all my provisions and outfit were lost except my tent, which had been sent ashore for the Governor-general's wife. This, together with my valise, camera, guns, and ammunition, was all that I had to show for the careful preparation I had made.

My Russian friends had not enjoyed their stay on shore under the trying conditions. We threw overboard for their use all the ducks and geese, which, after disporting themselves a few minutes in honor of their new-found liberty, made their way to the shore, where they were speedily despatched with axes by the gentlemen in patentleather boots and gold lace. We also consigned a pig to the vasty deep and it nobly struggled ashore only to meet the common fate of succulent pork. Through the glass I could see the Governor-general in his swell regimentals with a row of medals across his breast lugging an armful of driftwood along the shore to the fire.

And so we made our way back to Korsakovsk, a 
very discouraged and bedraggled company. The Governor-general took me to the house of the chief magistrate, where I was given a comfortable room, and could once more sit down to a good table. That night $I$ ate my first genuine Russian dinner. Each person as he enters a dining-room, faces the icon which hangs in the corner, and bows and crosses himself. The table was loaded with tinned preserves, pâté de foie gras, caviar, salted salmon, herrings pickled, and raw fish, sardines, cheese, sliced raw onions, cold sausages, raw cabbage, and huge piles of black and white bread. There was also the usual large carafe of pure white vodka, a powerful distilled liquor made from rye. Before eating, every glass is filled and the host's health is drunk to the accompaniment of "Butches sd rovia," which means, "Your good health."

In eating, you must reach for what you want. It is very seldom that anything is passed during this first stage of the meal. You would never suggest to your neighbor on the right to pass you the cheese; but you would rise in your place and, with a firm grasp on your knife, reach over his plate and impale the tempting morsel. If this is not possible, you leave your place and go around the table and secure your loot. There is only one thing that they will readily pass, and that is the vodka. The general aspect of things is that of a 
well-patronized free-lunch counter when the train is to start in five minutes. It must be confessed that Russian table manners are not fashioned on ordinary European models. They closely resemble the Korean method of eating at a public feast, when all the food is put on the table at once.

It is a mistake to suppose this terminates a Russian dinner. It has only begun. By this time the uninitiated is full to repletion unless he has been forewarned, but to the Russian this is but the ante-prandial overture. Everything is now cleared off the table except the vodka, which is never out of sight, and the dinner proper begins with soup. I must say that this soup is the heaviest and richest it has ever been my fortune to taste. Alone, it would form a full meal for any one less robust than the ordinary Russian. Each guest adds to his soup two or three heaping spoonfuls of sour whipped cream.

Their method of eating soup appeals as much to the ear as to the eye. Perhaps they go on the principle that soup must be eaten as audibly as possible, for this means that it is so good you cannot wait for it to cool.

My Russian naturalist, Alek, was a fair sample of an educated Russian, and he turned to me and said:

"I see that you eat with a fork."

"Yes," said I; " and I see that you do not." 
"No; but I had a sister who studied at an English convent in Japan for a year or so. When she came back she ate with a fork, but we soon laughed her out of it."

The end of the Russian knife is broader than the portion next the handle, and it is used both as a knife and as a spoon. They complain that the American knives do not " hold" enough.

After the soup came fowls, roast meats, vegetables, and two or three more dishes made of whipped cream. These last one grows to like. Their favorite form of dessert is this same sour cream, sprinkled generously with sugar and ground cinnamon. When all is seemingly over the table is again cleared, and the samovar is placed steaming upon the table. Every one takes four or five glasses of hot tea, flavored with sliced lemon. Some of the Russian tea is very fine. It is well known that they drink the costliest as well as the cheapest grades. It is more than likely that not a pound of the very best tea grown in China ever gets farther west than Russia.

Meanwhile every one is smoking cigarettes, men and women alike; not only after dinner but between the courses.

My use of the fork was not the only thing that distinguished me while in the country of the White Czar. Wherever I went, the Russians were highly amused at my use of the tooth-brush, 
which they consider a peculiarly feminine utensil. I was everywhere embarrassed by the total absence of the wash-bowl. Such things seem to be unknown. A sort of can or ewer of water, with a valve in the bottom, lets out a little stream of water on the hands; or, oftener still, a mouthful of water is taken from a glass and spurted over the hands-a much more sanitary method than the American, since the Russian does not wash in any vessel which has been used by others. The Russian objects to any bath excepting the elaborate Russian bath, and as this can be obtained only in the centers of population, the result is not edifying. Even on the steamer, where hot and cold baths could be had for the asking, the bath-room was not patronized. The Russians say of the English and Americans that they bathe so much that they emit an offensive odor, which turns the tables on us somewhat surprisingly and casts some doubt upon the truth of the proverb that virtue is its own reward. As black, the most somber of all colors, is in truth a lack of all color, so perhaps the lack of any distinctive odor in the well-tubbed Englishman strikes the Russian as unpleasant.

One of the waiters in attendance was a young and handsome man of twenty-five, convicted of murder. He was dressed in the picturesque costume of the Cossack, and, strangely, wore a dag- 
ger at his side. The woman who brought in the samovar had killed an entire family: her husband, father-in-law, mother-in-law, and her own child. She had been married to the waiter a year since arriving at Saghalien. The intermarriage of criminals raises a delicate penological question, considering what the fruit of such unions is likely to be.

After dinner, I suggested to one of the Governor's aides that we take a stroll, but the local magistrate veteod this, saying that on no account must we go out on the street after six o'clock in the evening. Our lives would be in immediate danger, as murders among the convicts averaged one a day on Saghalien. Hundreds have broken away and escaped into the interior of the island, living on game, roots, and berries. Some roam the streets at night, looking for plunder, especially when a steamship is in harbor.

The following day we passed a building which seemed to be full of women. 'They were convicts recently landed. On stated days, those male convicts whose conduct has been uniformly good are taken to this building where the women are lined up and the men are allowed to choose wives for themselves. The women are quite willing to be chosen, but if they refuse they are not compelled to marry. Marriage means that they get away from the confinement of the workshops and gain 
a snug little home among the neighboring hills, with nothing to suggest penal conditions except an occasional inspection. If they consent to marry, they go immediately to the little cathedral and are married by the priest. A plot of land is allotted to the couple, to clear and cultivate. Possibly a horse, a cow, and a few chickens are given them, as well as the inevitable samovar. Our saying, "What is home without a mother?" might well be rendered in Russian, "What is home without a samovar?" All the money that they can make by raising produce is their own, and will be turned over to them upon the expiration of their sentences. But most of the convicts on Saghalien have sentences which terminate only at death.

The women in the prisons are kept busy making clothes for such convicts as have not been let out on good behavior.

The following day I was invited to attend, at the Greek Church, a service of thanksgiving for the escape of the passengers and crew of our wrecked steamer. The service proved a very impressive one. The singing, by a choir of convicts, was especially fine. In these Russian churches seats are not provided, and the audience stands or kneels during the entire service.

That afternoon I had the temerity to take my camera under my arm and stroll through the 


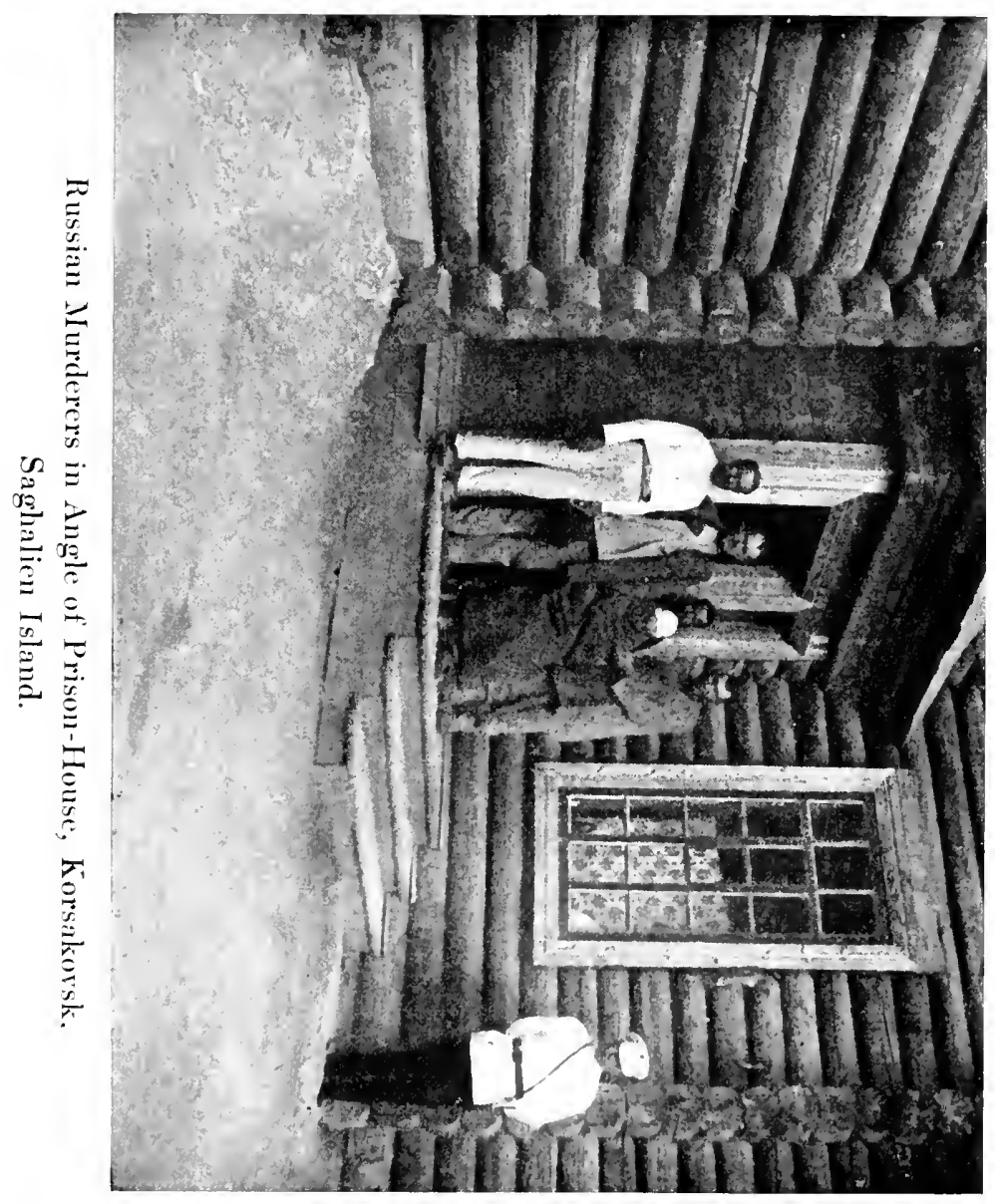



prison grounds. To my great surprise, I was permitted to take what photographs I pleased. Even the guards lined up and were "snapped," much to their delight. I also secured a picture of a convict being knouted for some slight misdemeanor. This is very common, and is done by tying the offender to a bench, face down, and inflicting the necessary number of blows on his back.

As the light began to fail I remembered the magistrate's injunction about being indoors before dark, and so made my way home to dinner, during which I sat at the same table with the magistrate. $\mathrm{He}$ was a man of considerable ability, and made good use of the English language. During the meal he leaned over toward me and said, smiling:

"I understand you have been taking some pictures."

"Yes," I answered penitently.

"Well, of course that is against the law, and I am afraid I shall have to ask you to turn those plates over to me."

I expostulated mildly, but found that his mind was firmly made up on the matter. To tell the truth, my mind was also made up on the matter.

"But," said I, "the plates are still in the camera, undeveloped."

"Oh, well, bring your camera along and I will 
develop them for you," - this with a little smile of amusement.

" Shall I go now," said I, pushing my chair back from the table, although dinner was not half over.

"Don't think of it. To-morrow morning will do just as well."

And to-morrow morning surely did, for that night the camera went to bed with ine, and when the magistrate smilingly drew out the plates next morning and cracked them, one by one, on the corner of the table, he was not aware that he was spoiling fresh plates. I tried to look as sad as the occasion seemed to demand.

I asked him if any of the convicts ever escaped from the island. He gave a short laugh and said:

"Some of them got away once. I will tell you about it. A Japanese fishing-schooner put in here under stress of weather and anchored off the town. That night eight of the convicts swam off to her, murdered the crew, and sailed away without the slightest knowledge of navigation. After drifting about aimlessly for several days, they were picked up by an American whaler and carried to San Francisco. As soon as the facts became known, the Russian authorities demanded their extradition, but the American papers took the matter up and made a great outcry about sending back these innocent political convicts to 
the horrors of Siberia, while the ladies of San Francisco heaped confections and flowers upon them. The United States authorities declined to give them up, though it should have been well known that no political suspects are ever sent to Saghalien, only tried and condemned criminals. But mark the sequel. Within two years all but one of those eight men were hung for murder, and the remaining one was in prison for life. We appreciate the kindness of the United States in relieving us of the support of these criminals, and she can have all the Russian convicts on the island of Saghalien if she wants them, and welcome."

Saghalien is Russia's gallows, and the incident given above shows how philanthropic zeal, if illinformed and misdirected, may easily work harm.

Having occasion to interview the barber, I entered a neat shop in company with a Russian official. It was not till the razor was playing about my chin that I learned that the barber was a common murderer. There was no backing out, for I knew not what savage instincts $I$ might arouse in him by proposing to leave his place half shaved. I generally manage to get a nice little nap when under the soothing influence of the barber's hand, but this time I confess that I remained rather wider awake than usual. The gentle reader can, perhaps, imagine my feelings as the keen steel

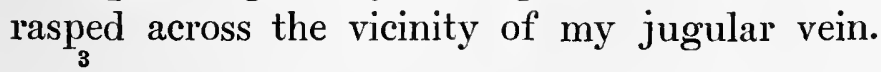


Strange to say, the only image that remains in my mind's eye is a staring advertisement which hung against the wall, and which expatiated with Yankee modesty upon the merits of a certain American barber-supply house and the unique opportunity it offered of securing the best goods at the cheapest price. I was informed later that this barber combined with his tonsorial occupation that of procurer, which shows how wide a range of pursuits Russia allows her convicts.

A superficial examination of the various shops which lined the main street of the town showed that American canned goods, sheetings, prints, flour and other food-stuffs are most in demand. The hardware was mostly of cheap German manufacture. I saw no English goods displayed. 


\section{CHAPTER III}

PETROPAULOVSK AND SOUTHERN KAMCHATKA

Volcanoes of Kamchatka and the superstitious natives-The first prospecting trip-Copper found, but no gold-Mosquitos cause an evacuation of the land-The typical Chinese peddler.

U

YPON our return to Korsakovsk from the wreck, the Governor-general had immediately telegraphed the news of the disaster to Vladivostok, and had asked that a relief steamer be despatched at once. In six days we saw her smoke on the horizon, and soon the Swatow, flying the German flag, cast anchor off the town. She was accompanied by a Russian gunboat, which carried the Governor-general and his suite back to Vladivostok, as he had been recalled on urgent business.

I found that the $S$ watoro would not be able to go up into Bering Sea, but could only visit the trading stations on the Okhotsk Sea, at the head of which lies the important town of Ghijiga. Although my outfit had been so terribly depleted in the wreck, I was determined to push on and live on the country if necessary. The 
steamer had brought me a small supply of bricktea, sugar, and hard bread. This slender store I supplemented as best I could from the shops in Korsakovsk, and boarded the Sroatow en route for the north.

On leaving Saghalien for the second time, we gave the southern point of the island a wide berth, and after ten days of uneventful steaming we sighted the shores of the peninsula of Kamchatka, which showed a chain of lofty snow-covered mountains, now and again hidden by dense banks of fog.

We entered the magnificent harbor of Petropaulovsk by way of a narrow passage, and found ourselves in a landlocked bay, twenty-five miles long and ten miles wide. Its shores were well wooded, and we could see several fine streams as they made their way swiftly down the mountain-sides to the waters of the bay. At the northern extremity of the harbor rose the active volcano of Avatcha, sixteen thousand feet high from the water's edge. About its summit lay heavy masses of snow, and above it hovered a thick blanket of smoke. Kamchatka lies in the line of volcanic activity which stretches from Tierra del Fuego in South America northward through South and North America, the Aleutian Islands, Kamchatka, the Kurile Islands, Japan, and so southward; and, therefore, it is not surprising that 


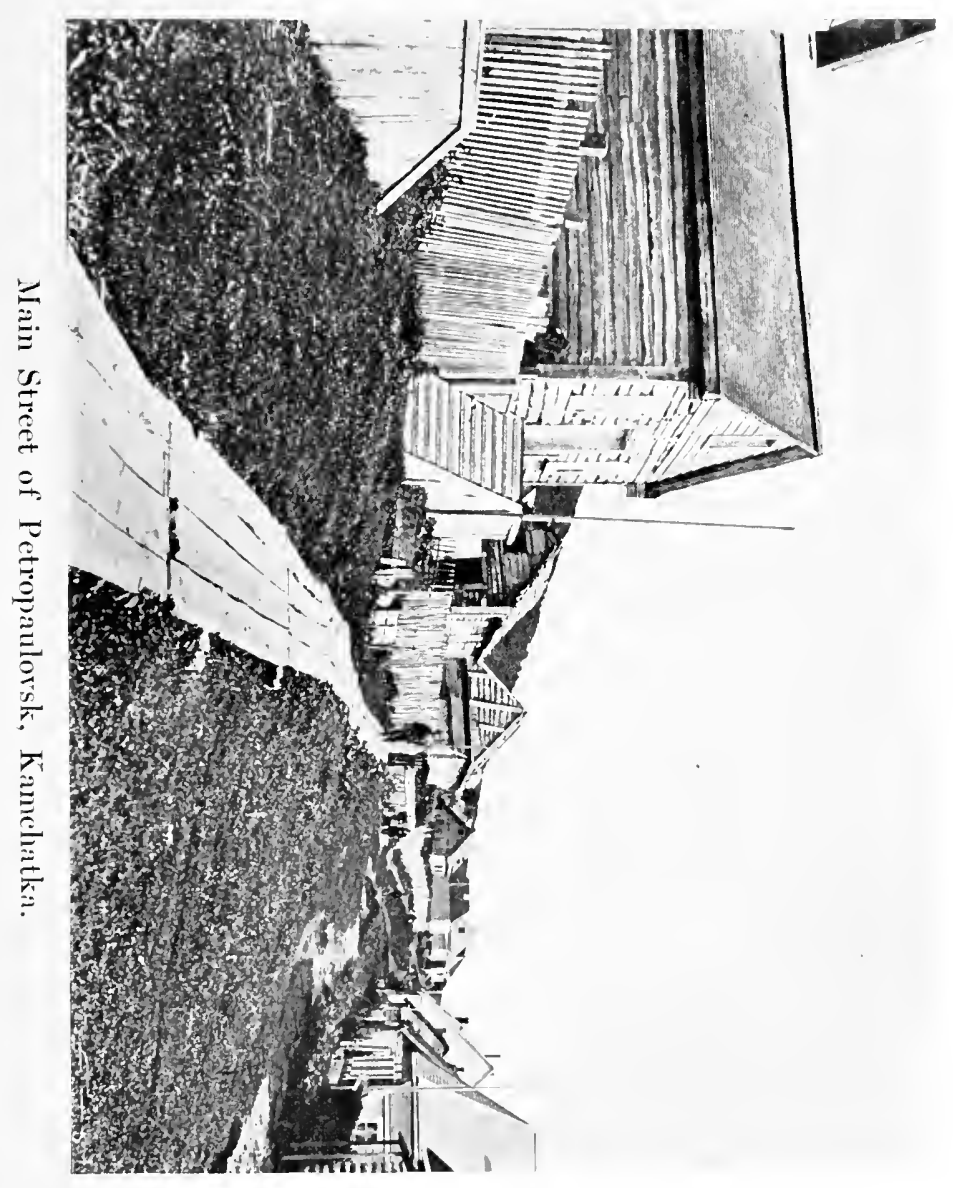


there should be many semi-active volcanoes on the peninsula as well as many hot springs. The natives consider both of these the habitations of evil spirits, and will not go near them if it can be helped. Once a party of Russians forced the natives to show them the way to one of the hot springs, and when the superstitious people saw the foreigners looking over the edge of the spring, tasting of the water and cooking eggs in it, they were filled with wonder, and thought the Russians had power over the demons. In port we found the British gunboat Archer and a small Russian gunboat.

The town of Petropaulovsk consists of about three hundred Russians and half-caste Kamchadales, presided over by a Russian magistrate, assisted by a secretary, a physician, and twenty Cossacks. With the exception of an imposing cathedral, the houses were all built of logs and one story in height, but they were neat and substantial, and were provided throughout with double windows, which are required by the severity of the winter.

At that season of the year the country was covered with a luxurious growth of vegetation. Of trees, so called, there are only the larch and birch, but the whole country is covered with a dense growth of underbrush, ten feet high, which it is impossible to penetrate. Consequently, very 
little traveling is done in summer, except on the rivers in small boats. Most of this undergrowth dies down at the approach of winter, and the snow which then covers everything makes traveling comparatively easy in any direction.

As our steamer was to make a little side excursion of ten days to different trading ports in the vicinity and then return to Petropaulovsk, I determined to remain behind and explore the region in search of copper deposits, which had been reported to exist in the vicinity. I secured a stanch little skiff built in San Francisco, and after stowing away my tent in the bow I started out to prospect along the beach. For the most part, I walked while the Koreans rowed the boat a little offshore, keeping always within hailingdistance. I carefully examined the mineral formations along the shore. About five miles from the town, I came across numerous pieces of copper "float" (detached fragments from the parent ledge). Striking up the hill above the point where this "float" lay, I found the outcroppings of a thin seam of bornite, which is a valuable copper ore if found in quantities. But the thinness of the seam was not promising; so I simply set up a claim post, which would hold it for three years, with a view to further exploration.

When night closed in, which in that northerly region in summer does not occur till nearly ten 
o'clock, we pitched our camp beside a brawling mountain stream, prepared our supper, and felt sure of passing a comfortable right. But within ten minutes we were undeceived. The mosquitos came down by the millions, and we surrendered at discretion, capitulated with the honors of war, went out with colors flying and side-arms on, so to speak, and spent the night in the boat, anchored some fifty yards from the shore.

It is not necessary to follow the fortunes of this little side excursion, as it did not result in finding any evidences of valuable deposits of copper. So at the appointed time we found ourselves back at Petropaulovsk, ready to resume our journey toward the north. We found the Swatow in port and scheduled to sail the next morning.

'The anchor came up at dawn, and before night we lay again at anchor at the mouth of the Tigil River, on the western coast of the peninsula. We found most of the population of the little village of Tigil awaiting our arrival. 'This village, composed of a mixed Russian and half-caste population, lies about forty miles up the river; but the villagers had all come down to the coast to meet the steamer, to fish, and to get away from the mosquitos, which are far worse inland than on the coast. They were all living in little temporary summer huts.

The first person I met as I stepped ashore ad- 
dressed me in good western American. He was Mr. Fletcher, a Russian subject, born in Kamchatka of mixed American and Russian parentage. He had been educated in San Francisco. $\mathrm{He}$ invited me to his little cottage and set before me a tempting meal of fresh milk and blueberries, supplemented by raw, salted and smoked fish, vodka, and the contents of the steaming samovar. After doing honor to these good things, we strolled down to the beach to watch the Chinese sailors from the steamer lay out the little stock of goods that they are allowed to bring with them to barter with the natives. The thrifty Celestial spreads a piece of canvas on the ground, and on it arranges in the most tempting manner his stock of hand-mirrors, needles, buttons, soap tablets, perfumery, and other articles de luxe. A bevy of native girls crowd about him, giggling and chaffing, while men elbow their way in to buy presents for their sweethearts, paying for them in deerskins, fur gloves, and smoked deer tongue.

Meanwhile the steamer has been busily discharging the quota of flour, tea, vodka, and other things which are required by the officials and traders of the station, and in return loading the bales of skins and furs consigned to the Russian Chartered Company. 


\section{CHAP'TER IV}

SALMON-FISHING IN THE FAR NORTH

Tide that rises twenty-five feet-Wholesale suicide of salmon-Fish-eyes as a delicacy for sea-gulls-How the natives store fish for the sledge-dogs-The three varieties of salmon-An Arcadian land for the birds.

\section{IAVING the mouth of the Tigil River, we} steamed northward into the upper arm of the Okhotsk Sea. The shore line showed rolling hill and mountain country without much timber. Three days of steady steaming brought us to the extreme limits of the Okhotsk Sea, at the mouth of the Ghijiga River. Owing to the shallowness of the water, we were obliged to anchor eighteen miles off shore. We had on board a small steamlaunch, for use in towing the lighters to the shore, each lighter carrying about twenty-five tons. The launch and lighters were soon put over the side and their cargoes loaded into them. At ten o'clock at night we set off toward the shore. It was necessary to start at that hour in order to get over the bar at flood-tide. We entered the mouth of the river at three in the morning. The sun was already up. The width of the estuary was con- 
siderable, but it was enormously increased by the tide, which rises twenty-five feet and floods the fields and plains on either side. The air was literally full of sea-gulls, flying very high. Some of them were going inland, and some out to sea. The odor of decaying fish was almost overpowering, and was plainly perceptible five miles out. This was caused by the enormous number of dead salmon that lay on the bar, having been swept down the river.

About the tenth of June the salmon come in from the sea and work their way up the river until the lack of water bars their further progress. Salmon do not run up these rivers until they have attained their sixth year of growth. From the moment they enter the fresh water of the river, they get no food whatever. For this reason they must be caught near the river's mouth to be in good condition. The female, having gone far up the river, finds a suitable place, and deposits her eggs; after which the male fish hunts them out and fertilizes them. As soon as this has been accomplished there begins a mad rush for death. However many millions of salmon may run up the river, not one ever reaches the sea again alive. 'They race straight up the river', as if bent on finding its source. When the river narrows down to two hundred feet in width, and is about a foot deep, the fish are so crowded together that the 


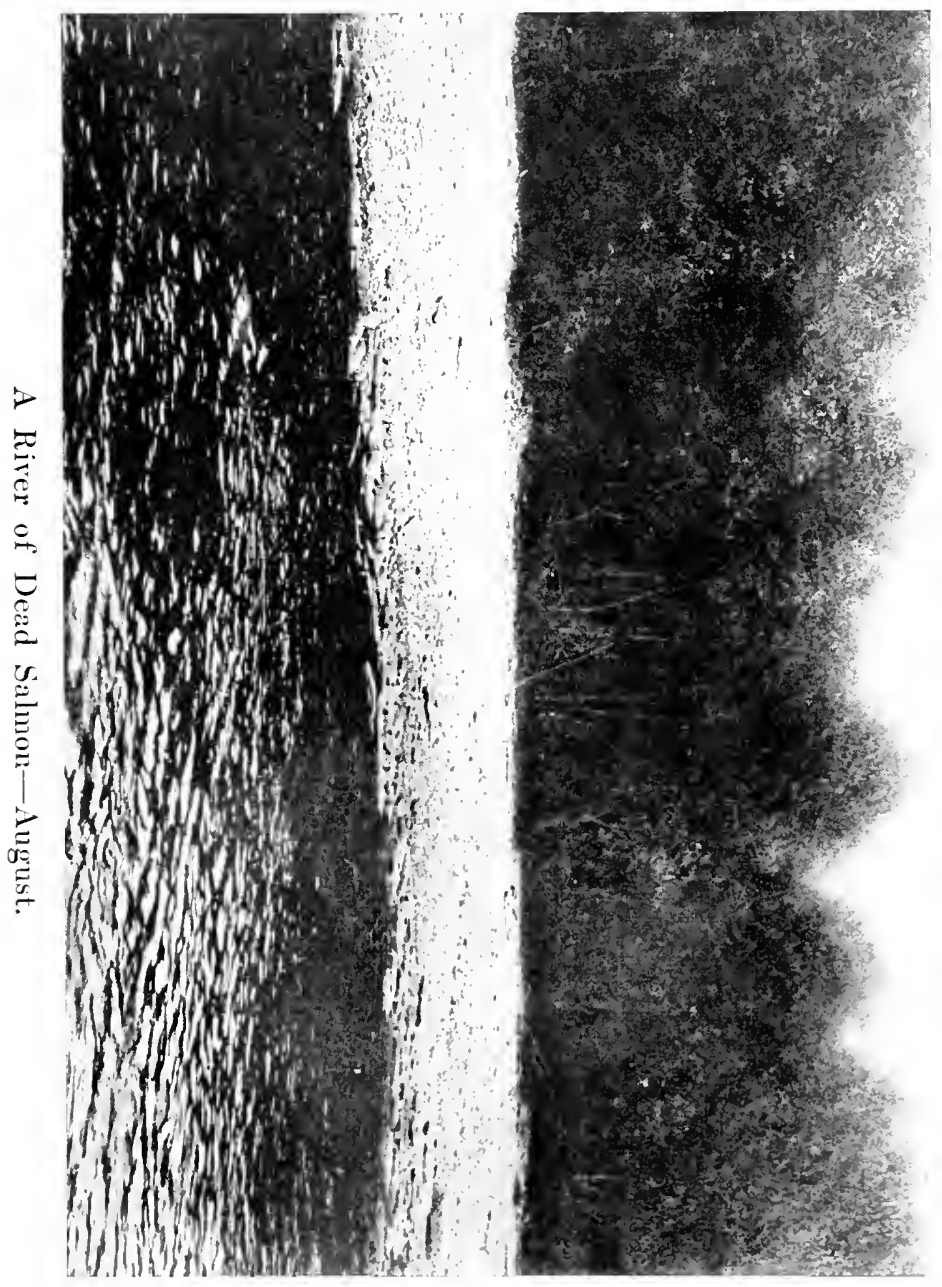



water fairly boils with them. And still they struggle up and ever up. One can walk into the water and kill any number of them with a club. After the fish have gone up the river in this fashion for fifty or sixty miles, they are so poor that they are worthless as food, for they have been working all this time on an empty stomach. As they fight their way up, they seem to grow wilder and wilder. Whole schools of them, each numbering anywhere from a hundred to a thousand, will make a mad rush for the shore and strand themselves. This is what the gulls have been waiting for. They swoop down in immense flocks and feast upon the eyes of the floundering fish. They will not deign to touch any other part. Bears also come down the river bank and gorge themselves. I have seen as many as seven in a single day, huge black and brown fellows, feasting on the fish. They eat only certain parts of the head, and will not touch the body. They wade into the water and strike the fish with their paws and then draw them out upon the bank. Wolves, foxes, and sledge-dogs also feast upon the fish, and for the only time during the year get all they want.

As the fish get further and further away from the sea, their flesh grows loose and flabby, the skin sometimes turning black and sometimes a bright red. They dash themselves against stones, and 
rub against the sharp rocks, seemingly with the desire to rub the flesh off their bones. The eggs of the salmon remain in the river during the winter, and it is not until the following spring that the young fish are swept down to the sea by the spring floods.

Along the banks of the river live the half-breed Russians and the natives in their miserable shanties and skin huts. They fish with long nets made of American twine. Fastening one end of the net to a stake on one side of the river, they carry the other end to the opposite side. In an hour or more, the farther end is brought back with a wide sweep down stream, which, of course, is the direction from which the fish are coming. The two ends are brought together, and a team of a dozen sledge-dogs hauls the net to the bank. The children kill the fish with clubs. Then they are carried to the women, who squat upon the sand, and, with three deft sweeps of a sharp knife, disembowel them, and cut off the thick pieces of flesh on each side of the backbone. These pieces are dried in the sun and form the chief article of food among this people. It is called by them yukulle. The backbone, the head, and the tail, which remain after the meat is cut off, are then dried, and they form the staple food for the sledge-dogs.

After they have cut up enough fish for one year's consumption, they make yet another large 


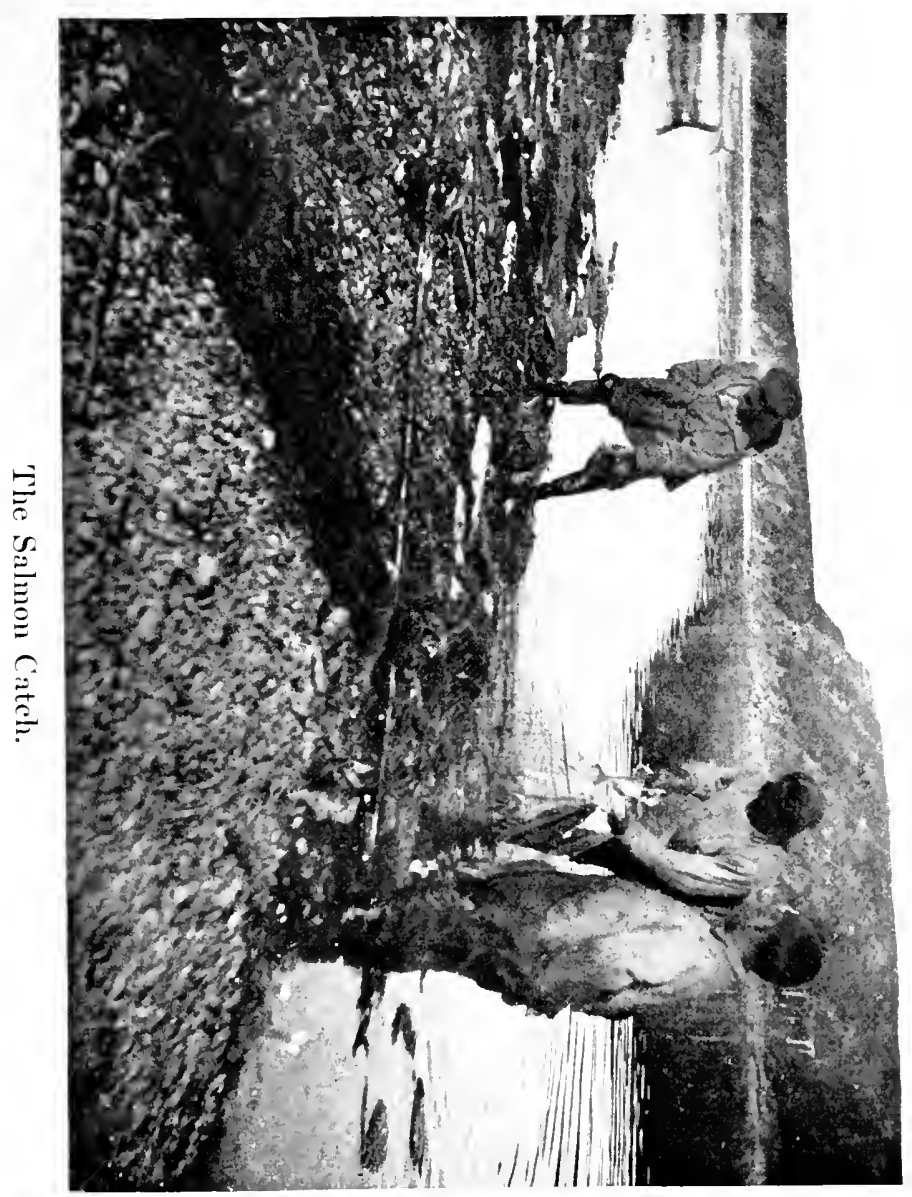



catch and throw the whole lot into a pit and cover them with earth. If there should be no run of fish the following year, these pits could be opened up and the contents fed to the dogs, thus saving their valuable lives. The natives, who live mainly on fish, will not cure more than enough for a single season's use.

They may lay up future store for their dogs, but not for their children. When an old fish-pit is opened up the stench is terrible, but this does not trouble the dogs, for they will eat anything into which they can bite. If the natives were willing to work fifteen days longer, they could easily lay up enough food to tide over any ordinary famine, but they will not do this unless forced to it. Consequently, the Russian Government compels one or two from each family to work on certain government nets, every fish caught being put in the "fish-bank" and a record kept of the exact number due each individual who helps work the nets. During several successive good years, enough fish are laid up to supply the people at least in part during times of scarcity. If these should not suffice, the government would buy up reindeer from natives in the interior at fifty kopeks a head, and feed them to the destitute people. Fifty kopeks make twenty-five cents in United States currency, which seems a small price to pay for a reindeer, but in the country of 
which we are writing that is a good average price. A failure of the fish crop occurs about once in seven years. For some reason not yet ascertained, the fish will entirely desert a river for a season. Not infrequently it is found that of two rivers whose mouths are not more than a few miles apart, the salmon will frequent one and not the other.

The Russian Government forbids the export of salmon caught in the rivers or within two miles of their mouths. While the people do not destroy a thousandth part of one per cent. of the fish that run up the river, we must bear in mind that not a single fish gets back to the sea after depositing its eggs. As the fish are killed as near as possible to the river's mouth, an enormous number of eggs are destroyed. There is, therefore, a possibility of seriously diminishing the supply if a wholesale slaughter takes place when the fish come in from the sea. If they were taken after the eggs are deposited it would be another matter; but this is never the case.

These salmon are of three different varieties, called, respectively, the silver salmon, the "hump-backed" salmon, and the "garboosh." The weight of a full-grown salmon is from eighteen to twenty-five pounds. There is in the rivers another fish called the salmon-trout. It has a dark-green back, with vivid pink spots, and it is 
a most delicious article of food. The little lakes in the tundra also contain a fish somewhat resembling the pickerel, which the natives catch in traps. These are set in the little creeks leading from the tundra lakes. They are cylindrical baskets, five feet long and three feet wide, and are set in an opening in a dam built, for the purpose, of reeds and stakes. Often as many as a dozen fish are taken from the traps at a single catch. At the time when the salmon are running, hundreds of sea-dogs (hair-seal) are attracted to the mouth of the river by the smell of dead fish. As we went in from our steamer, they kept lifting their heads from the water all about us, and afforded some good shooting. The natives take them in huge nets made of walrus thongs with a mesh of six inches or more. A good haul may net as many as thirty of these big fellows, which weigh up to four hundred pounds apiece. Their fur is of a mottled or speckled color. They are in high repute among the natives, who use their hides for boots. The women are able to sew them so as to be perfectly water-tight. The blubber is a delicacy which is eaten cold. It is also made into oil, and in a shallow dish, with a piece of moss for a wick, it forms the ordinary lamp of the native. The sea-gulls, on their way north to breed, arrive in May, and the air is simply filled with them. 
They make their nests on rocky declivities or beside the rivers, or even on the open tundra. The nesting and hatching of their young comes at such a time that it just matches the running of the salmon, which is very convenient. The young mature very quickly. When newly hatched they are gray. When they come back the following season only their wings are gray, the body being white. The egg harvest is a very important one to the natives, who preserve the eggs by burying them in the ground on the north side of a hill where there is perpetual frost. Besides the gulls, there are countless ducks, geese, and snipe. These last often fly in such dense flocks that the boys stand and throw clubs among them, and bring down half a dozen at a throw. These youngsters are also very skilful with the sling, and bag many ducks and geese with this primitive weapon. I have seen a boy bring down a single goose with one of these slings, though the general rule is to throw into a flock on the chance of hitting one. Birds of all kinds here find the richest feeding-grounds in the world. The sea birds, in countless numbers, feed upon the salmon, while the insectivorous birds have only to open their mouths to have them filled. At this season the ground is quite covered with berries, which have been preserved all winter under the snow. Among these are cranberries, blueberries, and 


\section{SIBERIAN KLONDIKE}

huckleberries. When the birds arrive in the spring they are generally poor, but ten days suffice, on this rich fare, to make them fat. An hour's stroll is enough to use up all the gun-shells one can conveniently carry, and to bag more game than one can bring home. The hunter has only to sit down in a "goose lane" or behind a blind of some sort, and shoot birds right and left. The few merchants who reside in these trading posts kill large quantities of birds in the season, and keep them in cold storage, which can be found almost anywhere a few feet below the surface of the ground. The natives, as a rule, are too poor to own shot-guns, and so do not profit largely by this generous supply of feathered game. 


\section{CHAPTER V}

\section{THE TOWN OF GHIJIGA}

The sacred icon and the sewing-machine both in evidence -The native "process of getting married"-Mrs. Braggin's piano-American pack-saddles and Russian obstinacy-Theodosia Chrisoffsky and his sixty descendants.

WEN we reached the shore, or as near the
shore as the shallowness of the water would permit, a crowd of natives and half-castes waded out and offered their backs to convey us to dry ground. 'There we found two Russian officers in uniform and twelve Cossacks, besides a hundred or more of the villagers. The magistrate and his assistant, with the aid of twenty Cossacks, govern a section of territory as large as Texas and New Mexico combined. The magistrate led us to his house, a log structure, one story high, with five large rooms. No carpets adorned the floor, which was spotlessly clean. On the wall hung the pictures of the Czar and Czarina, while in the cormer, of course, hung the sacred icon. One noticeable feature was a Singer sewing-machine. The mag- 


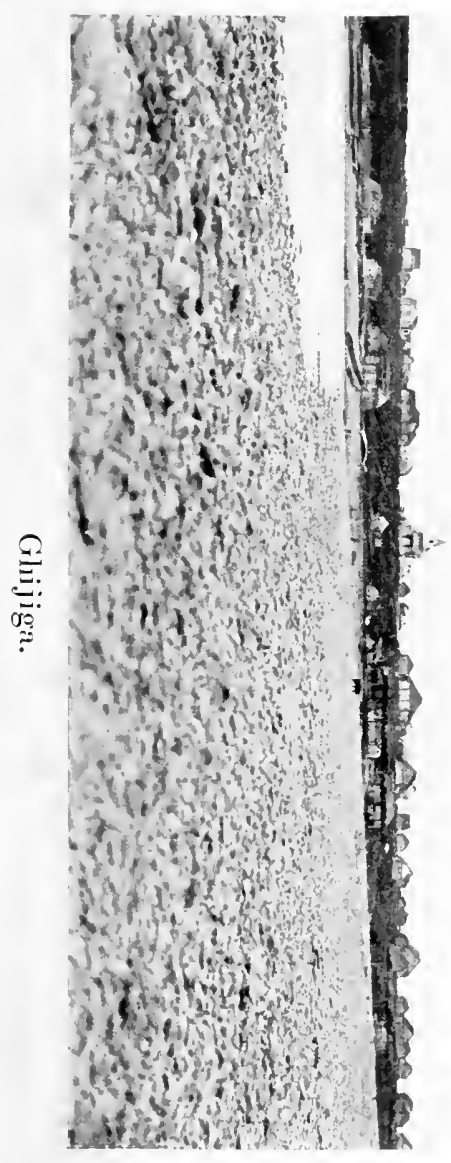



istrate's wife lives here with him and looks after their modest family of thirteen children.

It was now four o'clock in the morning, but the family were astir. The samovar was brought in, and over hot tea and buns we speedily became acquainted. The magistrate is an important man in Ghijiga, and I found him to be a highly educated gentleman, speaking French and German fluently, but not English. He examined my papers, and, with the aid of the supercargo, who interpreted for me, I told him the purpose of my visit. He made me entirely welcome, and told me that he had received orders from the Governorgeneral in Vladivostok to aid me in every way possible. And he assured me he would gladly do so.

My first object was to reach the town of Ghijiga, which lay twenty-five miles up the river. Here I intended to make my headquarters while I explored the country inland and about the head of the Okhotsk Sea. 'The magistrate immediately gave orders that a boat be gotten ready to take me up the river, and five Cossacks were detailed to haul at the tow-line.

After a hearty breakfast of salmon, reindeer meat, and other good things, we embarked and started up-stream. The boat was probably the worst-shaped craft ever constructed. It was made by hollowing out an eighteen-foot log, 
after which side boards were attached. As it drew fully twelve inches of water and was very cranky, one could scarcely recommend it for river travel. I afterward built three boats which would carry double the weight of cargo, and which drew only four inches.

We rowed up-stream a few miles in a northwesterly direction until we reached the limit of tide-water, and the stream suddenly grew shallow. The banks were covered with a dense growth of bushes, which at some places attained a height of twenty feet, but there was no large timber near at hand. With my field-glasses I saw some fairly heavy timber on the mountainsides inland. The general aspect of the country was exceedingly rough. The banks of the river showed outcroppings of slate, striking east and west, with a pitch to the south of forty-five degrees. 'To the southwest, about ten miles away, I saw a long, low range of hills, perhaps a thousand feet high. The highest point in this range is called Babuska, which is the Russian for " grandmother."

As we approached the shallows the water became so swift that we could no longer row, whereupon four of the Cossacks jumped out of the boat into the icy water. Putting over their shoulders a kind of harness made of walrus hide, to which was attached a rope of the same material 
one hundred feet long, they began towing. The fifth Cossack held the steering-oar. The shore was too heavily wooded to admit of using it as a tow-path, and so the poor fellows had to wade in the water. Frequently, the boat would ground on the shallows, and then they would patiently come back and haul us over the obstruction. At noon we landed, built a roaring fire, and imbibed unknown quantities of tea along with our lunch. Taking to the water again, we kept steadily, if slowly, on until seven o'clock, when, suddenly turning a sharp bend, we saw on the hillside, on the left bank, the green spires of a Russian church around which were grouped about fifty houses. I noticed that not a single house had a window on the north side. The severe winds from the north drive all the snow away from that side of the houses and pile it up against the windows on the south side, so that they are often buried truelve or fifteen feet deep. Some of the people are too lazy to dig this away and so have to remain in comparative darkness; but as the days are only a couple of hours long in mid-winter, it does not make so much difference.

As we neared the landing all the village, except such portion as had met the steamer at the mouth of the river, came down en masse to greet us-dogs, children, and all. They gave us a 
hearty drosty, or " How do you do?" and treated us most hospitably.

We pitched our tent on a grassy slope near the water and made preparations for supper. As I was bending over, busy with my work, I was startled by a hearty slap on the shoulder and the true Yankee intonation, "Well, friend, what are you doing in this neck of the woods?" I turned quickly and saw before me a stout, good-natured, smiling American. I learned that he was a Mr. Powers, manager of the Russian Trading Company, which had a station at this point. He had arrived a few days before in the company's steamer, the Kotic, and had brought with him a Russian-American as clerk. The latter was in process of being married to the daughter of a Mrs. Braggin, the capable agent of the Russian Fur Company at that point. I say he was in process of being married; for, although the ceremony had begun the day before, it would be several days yet before it would be completed. They literally dragged me up to the house, although I pointed in dismay at my disreputable suit of khaki. I was too late for the church service, but was just in time for the more substantial part of the festivities.

After the service in the church the villagers gather at the bride's house and spend the balance of the day in feasting, amid the most uproarious 


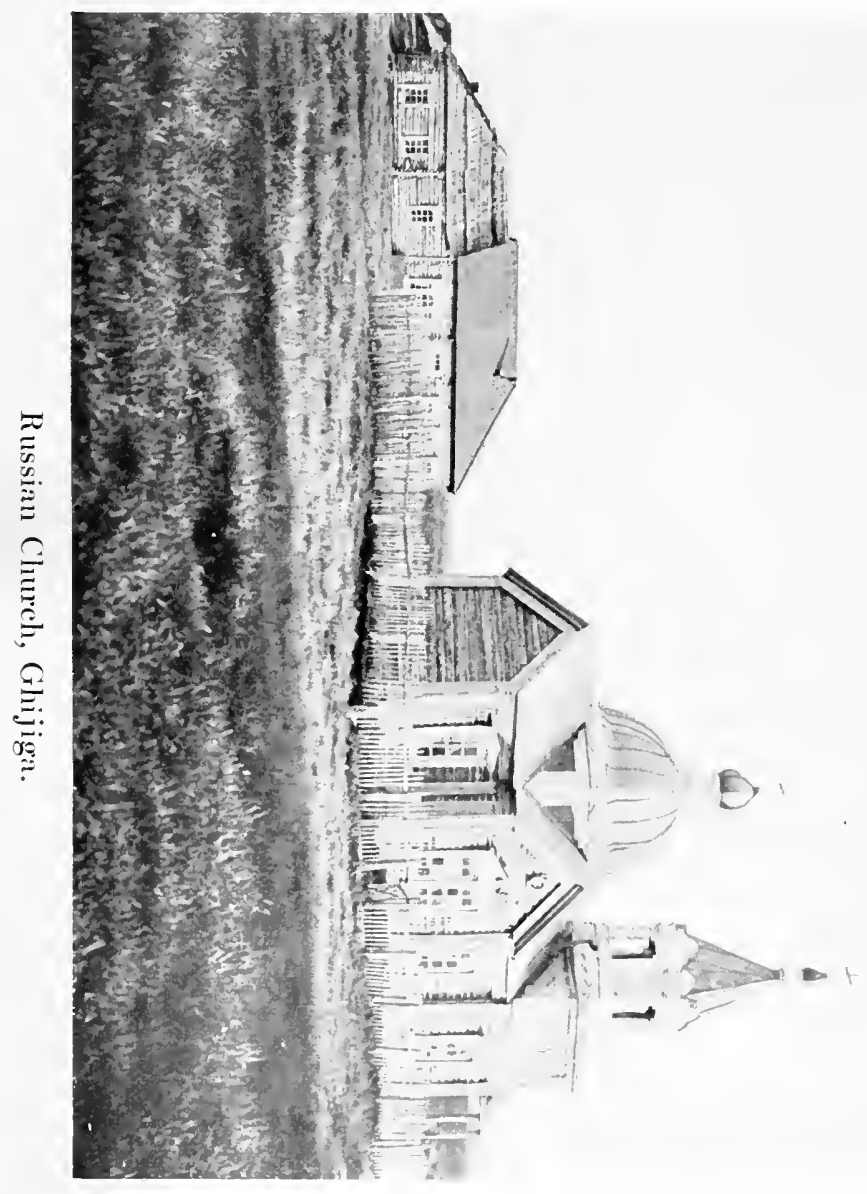



mirth. The second day finishes this act of the play, but on the third and fourth days the bride and groom make the round of the village, feasting everywhere. It was on the second day that we arrived, and before the day was over the groom had gorged himself about to the limit; and before the next two days had gone he confided to me the fact that if he had known how much he would be forced to eat, he would have hesitated before crossing the threshold of matrimony.

Mrs. Braggin's drawing-room boasted an antiquated upright piano, that had long passed its prime, but was in fairly good tune for such a corner of the world. In the course of the evening, as the fun was growing fast and furious, and there seemed to be no one to play the instrument, I sat down and struck up the "Washington Post" march; but before $I$ had played many bars, I was dismayed to find that the merriment had suddenly ceased and the whole company were standing in perfect silence, as if rooted to the spot. When I finished nothing would suffice but that I should exhaust my slender repertory, and then repeat it all again and again. Evidently, many of those rough but kindly people had never heard anything like it in their lives, and, as the Russian is musical to his heart's core, I felt pleased to have added my mite to the evening's entertainment. After the four days of feasting, we descended 
to the plane of the ordinary. By the aid of Mr. Powers I secured a vacant log hut, where I bestowed my various goods and appointed old Andrew as steward, making arrangements for him to board at Mrs. Braggin's. Some of the native women were easily induced to fit me out with a suit of buckskin which I should require in traveling about the country. In this whole district there were but twelve horses. They were Irkutsk ponies, shaggy fellows, about fourteen hands high. They were very hardy animals, and could shift for themselves both summer and winter. In the winter they paw down through the snow until they reach the dead grass.

After nearly exhausting my powers of persuasion, and paying a round sum, I secured six of these horses. I hired a competent Russian guide and prepared to take my first trip across the tundra, to examine a locality where the Russians had reported that gold had been discovered a few years before. With my horses came little Russian pack-saddles or rather combinations of pack- and riding-saddles. They have the faculty of turning with their loads about once an hour all day long. 'This I had discovered at Petropaulovsk, but when I expressed my determination to use my American pack-saddles, I found myself confronted by the opposition of Russians and natives alike. They viewed my saddles with 


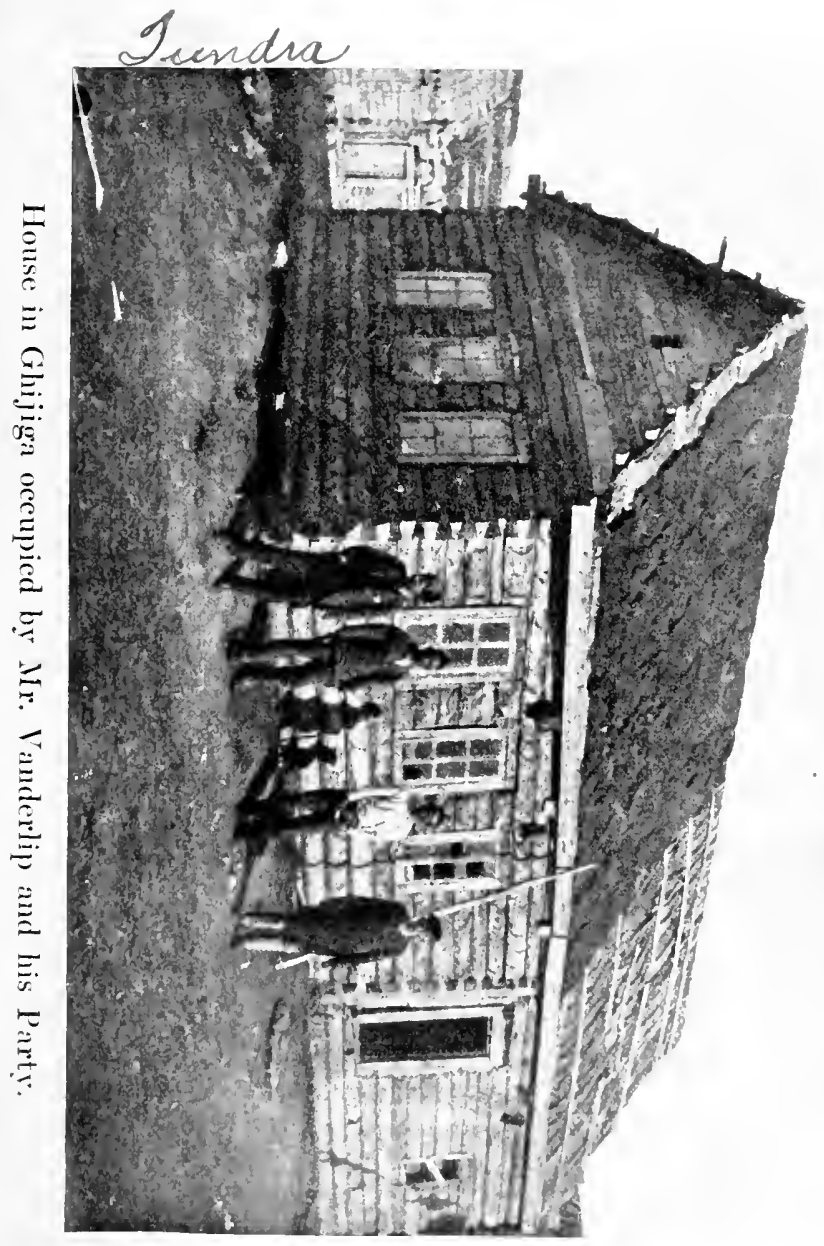



amusement and contempt. The double cinches and the breast and back cinches puzzled them completely, and they refused to have anything to do with them. As fast as my Koreans would get the packs on, the Russians would take them off when our backs were turned. I soon discovered that the Russians were determined to use their own saddles, and no argument would move them. I unbuckled a Russian saddle and threw it to the ground, substituting one of my own for it. I turned to a second horse to do likewise, when, looking over my shoulder, I saw a Russian quietly unfastening the first. Stepping up to him, I gave him a slap with the open hand on the jaw. Instantly, the whole matter assumed a new aspect. I was not to be trifled with. They saw it. Their objections were at once withdrawn, and never after that did I have occasion to strike a man.

My guide was an old man of sixty-five, but a noted sledge-driver and hunter. His name was Theodosia Chrisoffsky, a half-caste. He was a dried-up and wizened old man, but I found him as active as a youth of twenty. He was always the first up in the morning, and the last to bed at night. He owned the best dogs in northeastern Siberia, and could get more work out of a dogteam than any other man. His reputation reached from the Okhotsk Sea to the Arctic 
Ocean, and he was considered among the dog-men to be about the wealthiest of his class. He owned a hundred dogs, valued at from three to one hundred roubles each. Perhaps ten of them were worth the maximum price, and the rest averaged about ten roubles apiece. He also owned five horses. Not the least part of his wealth were twelve strapping sons and daughters, all of whom, with their wives and husbands, lived under the paternal roof-or, rather, under a clump of paternal roofs. There were some sixty souls in all, and they formed a little village by themselves about twenty miles up the river from Ghijiga.

I had to load the horses very light on account of the marshy condition of the tundra. Each pack was a hundred pounds only. On this trip I took only one of my Koreans. 


\section{CHAPTER VI}

OFF FOR THE TUNDRA-A NATIVE FAMILY

Hard traveling-The native women-A mongrel raceChrisoffsky's home and family and their ideas of domestic economy-Boiled fish-eyes a native delicacy-Prospecting along the Ghijiga.

WWE set out at nine o'clock on the sixth of September. Fortunately for us, the sharp frosts had already killed off all the mosquitos. The path through the tundra was very difficult. We stepped from tuft to tuft of moss, between which were deep mud and slush. When we could keep in the river-bed, where it was dry, we had tolerably good going; so we kept as near the river as possible. Often I would have to mount the back of my faithful Kim to cross some tributary of the main stream. We were continually wet to the knee or higher, and were tired, muddy, and bedraggled beyond belief.

Toward night, we saw the welcome smoke from the village of the Chrisoffskys. A crowd of small urchins came running out to greet their grandfather, and soon we were in the midst of the village. The old gentleman, my guide, took 
my hand and led me into his house, where, after I had kissed every one (drawing the line at the men), one of the daughters sat down on the floor, unlaced my boots, took off my wet socks, and replaced them by soft, fur-lined deerskin boots. She then looked my boots over very carefully, and finding a little seam ripped, she got out a deer-sinew and sewed it up. All my men were similarly attended to. The boots were then hung up to dry. In the morning, they would have to be oiled. This attention to the foot-gear is an essential part of the etiquette of this people. Any stitch that is to be taken must be attended to before the boot is dry and stiff. Even here the samovar reigned supreme. The women were strong, buxom creatures, and they wore loose calico gowns of gaudy colors. The hair, which is never luxuriant in the women of the North, was put up in two slender braids crossed at the back and brought around to the front of the head and tied up. Their complexions were very dark, almost like that of a North American Indian. Most of them had very fine teeth.

These people are of a mongrel race, having a mixture of Korak, Tunguse, and Russian blood. Chrisoffsky himself was one fourth Russian. They speak a dialect that is as mixed as their blood; for it is a conglomerate of Korak, Tunguse and Russian. They are very prolific, six 


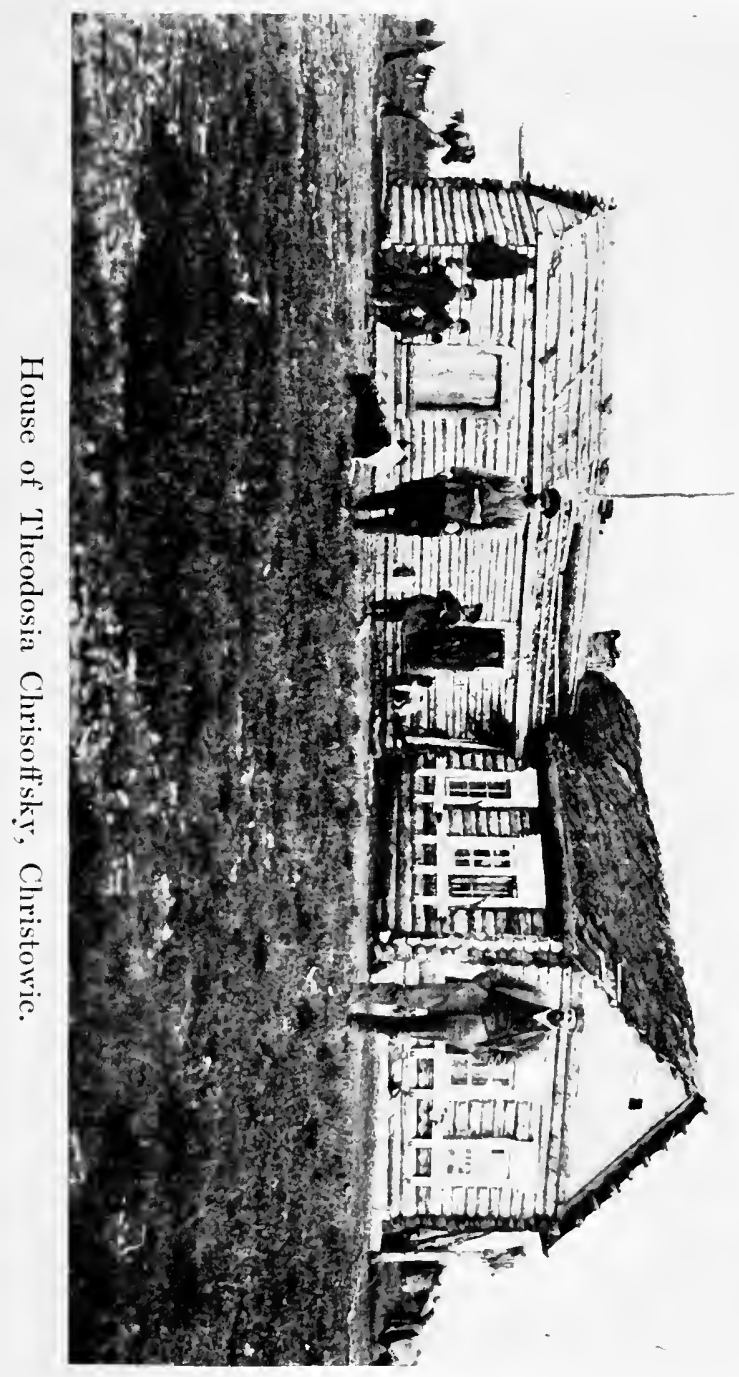



and eight children being considered a small family. The death-rate among them is very high, and, as might be expected, pulmonary diseases are responsible for a very large proportion of the deaths.

This house into which I had come as guest consisted of a kitchen, a small living-room, and a tiny bedroom. The old gentleman's wife was fiftyfive years old, and was still nursing her fifteenth child, which, at night, was swung from the ceiling, while the father and mother occupied a narrow bed. Three of the smaller children slept on the floor beneath the bed. The room was eight feet long and six feet wide. The fireplace in the living-room was a huge stone oven, which projected through the partition into the bedroom. Every evening its capacious maw was filled with logs, and this insured heat in the heavy stone body of the stove for at least twenty-four hours. In the mouth of this oven the kettles were hung. This house was far above the average; for, in truth, there were only twelve others as good in the whole immense district.

For dimner, the first course was a startling one. It consisted of a huge bowl of boiled fish-eyes. This is considered a great delicacy by the natives of the far North. When the dish was set before me, and I saw a hundred eyes glaring at me from all directions and at all angles, cross, squint, and 
wall, it simply took my appetite away. I had to turn them down, so that the pupil was not visible, before I could attack them. The old gentleman and $I$ ate alone, the rest of the family not being allowed to sit down with us. This was eminently satisfactory to me, as we ate from the same dish; in fact, I could have dispensed with my host too. The second dish consisted of fish-heads. I found on these a sort of gelatin or cartilage that was very good eating. Then came a kind of cake, fried in seal-oil, of which the less said the better. For dessert, we had a dish of yagada, which is much like our raspberry, except that it is yellow and rather acid.

The rest of the family, together with my men, squatted on the floor of the kitchen, and ate from tables a foot high by three feet square. In the center of each table was set a large bowl of a kind of fish-chowder. Each person wielded a spoon made from the horn of the mountain sheep, and held in the left hand a piece of black bread. After dinner they all had tea. No sugar is put in the tea, but a small lump is given to each person, and he nibbles it as he sips his tea. It is the height of impoliteness to ask for a second piece of sugar. Many of these people drink as many as sixty cups of tea in a single day. They seldom, if ever, drink water.

We sat and talked a couple of hours over the 
samovar, and then the blankets were spread for the night. The large room was reserved for me. Three huge bearskins were first placed on the floor, and then my blankets were spread over them. It made a luxurious bed, and quite free from vermin; for a bedbug will never approach a bearskin. In the kitchen, I fear, they were packed like sardines. They slept on deerskins or bearskins, anything that came handy being used for a covering. Curiously enough, these people all prefer to sleep on a steep incline, and to secure this position they use heavy pillows or bolsters. Before retiring, each person came into my room and bowed and crossed himself before the icon in the corner. I had to shake hands with them all, and kiss the children, which operation I generally performed on the forehead, as handkerchiefs are unknown luxuries in that country.

The next morning, while partaking of a sort of French breakfast of bread, tea, and sugar, I noticed that my party were the only ones that made use of a comb and brush. When I stepped outside the door to clean my teeth, I was surrounded by twenty or more, who had come to witness this strange operation. They were brimming over with laughter. The tooth-brush was passed around from hand to hand, and I had to keep a sharp lookout, lest some of them tried it themselves. 
Finally, I lined them all up to take their photograph. I placed my camera on the ground, and turned to direct them how to stand. I had no need to ask them to look pleasant, for they were all on a broad grin. I was at a loss to account for their mirth till I turned and saw that the village dogs were treating my camera in a characteristically canine fashion. Then it was I-who needed to be told to look pleasant.

At last we were on the road again. For the first five miles our way led up the bed of the river, sometimes in the water, and sometimes on the bank in grass as high as the horses' shoulders. When, at last, we came out on to the tundra, to the north, a hundred and fifty miles away, I could see the tops of the mountains among which the Ghijiga River has its source. They are about ten thousand feet high. To the northeast, about sixty miles away, I could see the foothills of a range of mountains in which rises the Avecko River, which enters the Okhotsk Sea within a mile of the mouth of the Ghijiga. Reaching the summit of the water-shed between the two rivers, I discovered that between me and these foothills the land was low and abounded in tundra lakes. To avoid these, I bore to the left and kept on the summit of the water-shed. By noon we had covered only eight miles. We halted for dinner, unpacked the horses, and turned them out to feed 


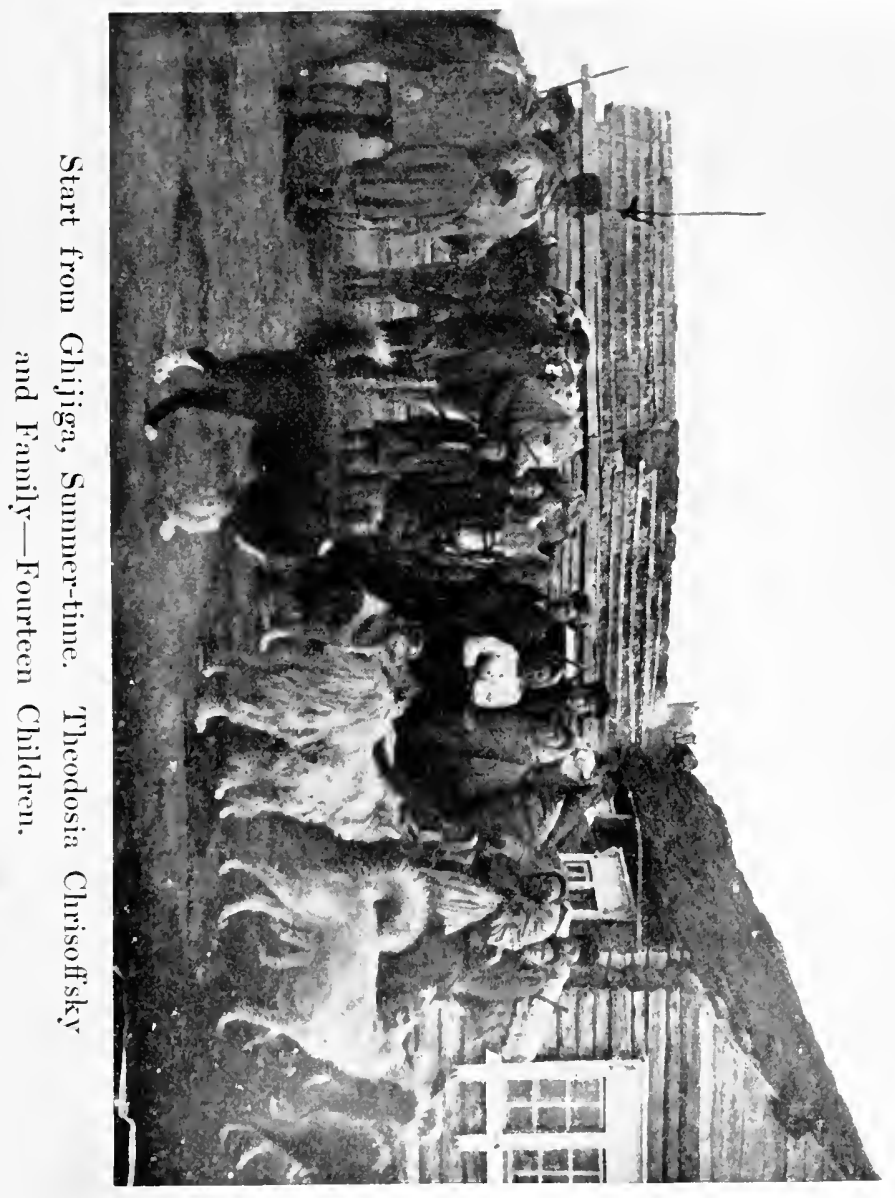



upon the rich grass while we made our dinner of fish, bread, and other viands which we had brought ready prepared from the house. At eight that night we camped on a " tundra island," a slight rise in the general flatness on which grew a few tamarack trees. As the nights were now very cold, we built a roaring fire. My koklanka, or great fur coat, with its hood, now proved its utility. After supper, which consisted of several brace of fat ptarmigan, brought down that afternoon with my shotgun, each man took his deerskin and spread it on a pile of elastic tamarack boughs. With our feet shod in dry fur boots, with our koklankas about us and great pillows under our heads, we slept as soundly and as comfortably as one could desire.

In the morning we found ourselves covered with white frost. The start was very difficult, for an all-day tramp in the bog the day before had made our joints stiff. For the first half hour, walking was so painful that I found myself frequently counting the steps between objects along the way. But after a time the stiffness wore off, and I began to find the pace of the horses too slow. When at last we came to higher ground and better going, I examined the streams for gold. The pan showed several "small colors," for we were in a granite country, but as yet there were no signs of any gold-bearing float rock. 
On the thirteenth day we arrived at our destination which was a certain creek indicated by a Russian engineer named Bugdanovitch. I liked the looks of the country very much. The creeks were filled with quartz float. So I determined to stop here two or three weeks and explore the adjacent hills and creeks for gold. At this point my guide's contract expired and I reluctantly let him go, as well as five of the six horses. I was thus left in the wilderness with Kim and Alek.

I pitched camp in a favorable place and went to work in good spirits. I thoroughly prospected the hills and ravines and made repeated trials of the creek beds, but though I found more or less show of gold, I was at last obliged to confess that there was nothing worth working.

This being the case, it behooved me to be on my way back to headquarters at Ghijiga. I thought there could be no difficulty about it, as the water all flowed in one direction. I did not want to go back by the way we had come. I suspected that there was a shorter way, and that the guide had purposely brought me a longer distance in order to secure more pay. So I decided to make a "bee line" for Ghijiga. Already we had had a slight flurry of snow, which had made me a trifle uneasy. We had only thirty days' provisions with us, and it would not do to be snowed in. As we had only one horse, we could not, of 


\section{SIBERIAN KLONDIKE}

course, take back with us all our camp equipage, so I left Alek at the camp and started out for Ghijiga with Kim and our one horse, intending to send back dog-sledges for the things. A more timid man than Alek would have hesitated before consenting to be left behind in this fashion, but he bore up bravely and in good cheer sent us off. 


\section{CHAPTER VII}

\section{TUNGUSE AND KORAK HOSPITALITY.}

My Korak host-" Bear!"-I shoot my first arctic foxMy Tunguse guide-Twenty-two persons sleep in a twelve-foot tent-Tunguse family prayers-The advent of Howka-Chrisoffsky once more.

I STRUCK what I thought to be a straight 1 course toward our destination. The going was much better than it had been a few weeks before, because of the hard frost which held everything solid till ten o'clock in the morning. Then the sun would melt the ice and make it very hard to travel; for the broken ice would cut our boots, which meant wet feet for the rest of the day.

On the second day we struck a small watercourse and saw many signs of reindeer. Soon we found a tiny trail, and, following it down the valley, I turned around a bend in the creek, and saw before me six large deerskin tents, while on the surrounding hillsides were hundreds of reindeer. As we neared the village a dozen curs came rushing out; some of them were hobbled so as to prevent their chasing the deer. They attacked us savagely, as is the custom of these ugly little mon- 


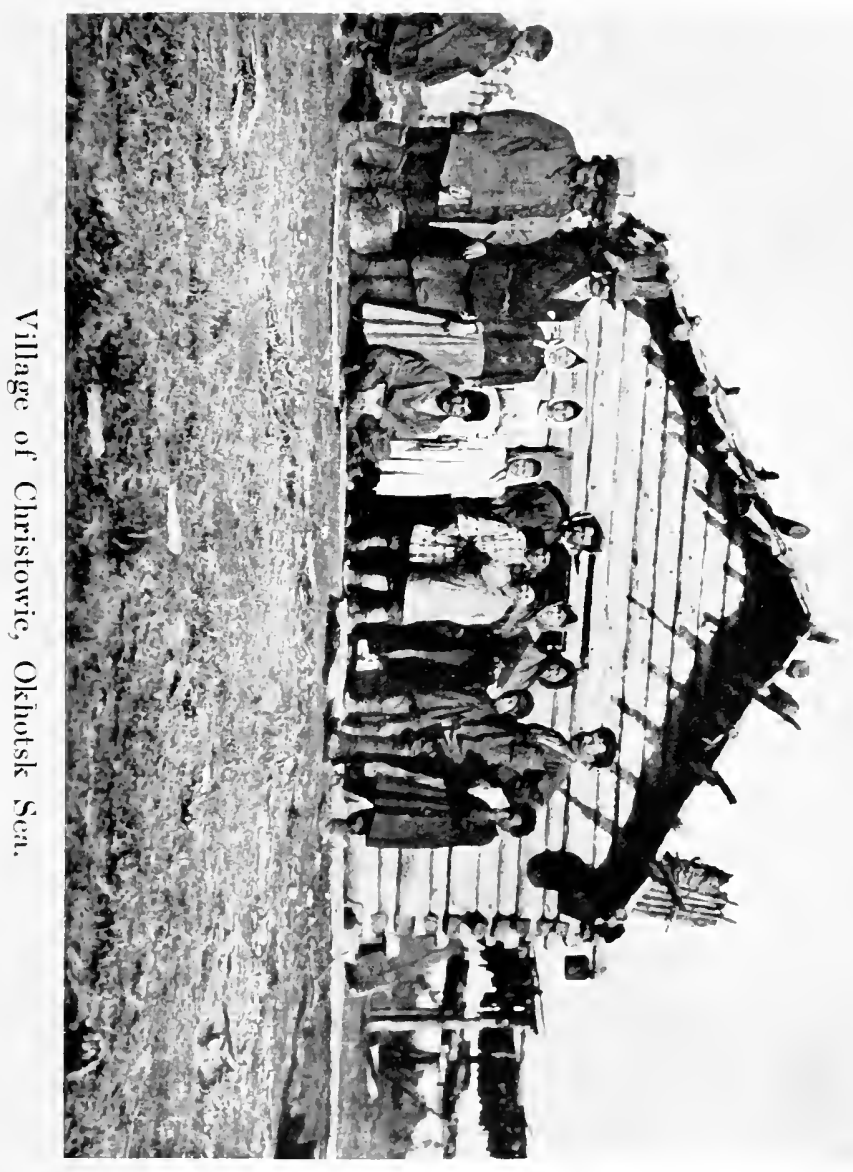



grels. We had to make a counter attack with stones to keep them off. The noise aroused the natives, who hurried out and received us with the hospitable " drosty."

These people were pure Koraks, ${ }^{1}$ a little under the medium size, in which they resemble the Japanese. I was led into the largest of the tents, and a wooden bowl containing boiled reindeer meat was placed before me. 'To the delight of my host, I went to my pack and produced some tea. I also displayed some sugar and black bread, which firmly established me in their good graces. I was greatly surprised to see my host bring out a box, from which he produced half a dozen china cups, heavily ornamented with gilt, and bearing such legends as "God Bless Our Home," "To Father," and "Merry Christmas." He must have secured them from an American whaling vessel on one of his annual trips to the coast. So, in the midst of this wilderness, I drank my tea from a fine mustache cup, originally designed to make the recipient " Remember Me." 'These cups were the heirloom of the family, and were brought out only on state occasions.

When tea was finished I produced some tobacco and filled my pipe and that of my host, much to his gratification. The sequel was em-

1 Sometimes spelled Koriaks or Koryakes. Korak is given the preference as being more accurately the phonetic spelling. 
barrassing; for when our pipes were smoked out he insisted on filling them again with his own tobacco. This was rough on me, but I set my teeth on the pipe-stem and bravely went through with it to the end. I can say nothing worse of it than that it was as bad as a cheap American cigarette.

My host was a genial old fellow, and later on he became my bosom friend. He was the wealthiest man in his district, and owned upward of ten thousand reindeer. Of course I had great difficulty in talking to him, but by a liberal use of signs, I made him understand where I had come from, and that I would like to have him kill some reindeer and carry them back to the camp where I had left Alek, and, if possible, bring him to this village. I made a rough sketch of the position of the camp, and he understood perfectly, as shown by the fact that he carried out my instructions to the letter on the next day. I asked him the way to Ghijiga and pointed in the direction that I had supposed it lay. This was approximately correct, but he promised to give me a guide to take me to town.

That evening there was another surprise in store for me. They served for supper the boiled flesh of unborn reindeer. It is accounted a specially choice viand among the Koraks. This seemed worse than smoking the old man's tobacco, but I laid aside all squeamishness and found that, after 
all, it was a palatable dish. My bed that night was a pile of skins, a foot deep, in a corner of the tent.

The next morning we set out with our guide, a mere boy dressed in a close-fitting suit of brown buckskin. He carried in his hand an ugly looking bear spear with a blade a foot long and sharpened on both edges. It was artistically inlaid with copper scroll-work and was a fine example of genuine Korak art. The shaft was a good eight feet long. All day we pushed ahead without adventure or misadventure until about seven o'clock in the evening, when, as we were passing down a gentle incline through thick bushes, with the Korak guide in the lead and I behind, my notice was attracted by a mound of fresh earth a few steps from the path. I went to investigate, and was greeted by a terrific roar. I brought my gun to position and cocked both barrels, but could see nothing beyond a tremendous shaking of the bushes. Looking around, I saw the little guide with his eyes blazing and his spear in readiness for an attack. He exclaimed "Medvait!" which in Russian means "bear." As my gun was loaded only with bird shot, I decided that discretion was the better part of valor, and slowly backed out of the dense undergrowth. When I reached the open, whatever remnant of hunting instinct a hard day's tramp had left in me asserted 
itself. Hastily reloading my gun with shells loaded with buckshot, I circled around the bushes to get a shot at the fellow. I saw where the bushes were being beaten down by his hasty retreat, but could not catch sight of the brute. I sent a charge of buckshot after him as an inducement to come out and show himself, but the argument worked just the other way, and he made off at his best speed. The strangest thing about the whole affair was that we had passed within ten feet of the animal without the horse showing any signs of uneasiness. Nothing will so frighten a horse as the smell of a bear. But I learned afterward that this particular horse was afraid of nothing. I had named him "Bill," and we had many a hard day together.

Night was now upon us, and so we made our camp in some dry grass beside a brook. The guide slept on a single deerskin, with no covering but the clothes he wore. In the morning I ascended a little knoll, and with my glasses could see a mountain near the town of Ghijiga, so the guide left me, and went back. That afternoon I killed my first arctic fox. The little fellow, about as large as a coyote, came running toward us. We stopped short, and the inquisitive animal approached to within a hundred feet and paused to inspect us. I killed him with a ball through the chest. 


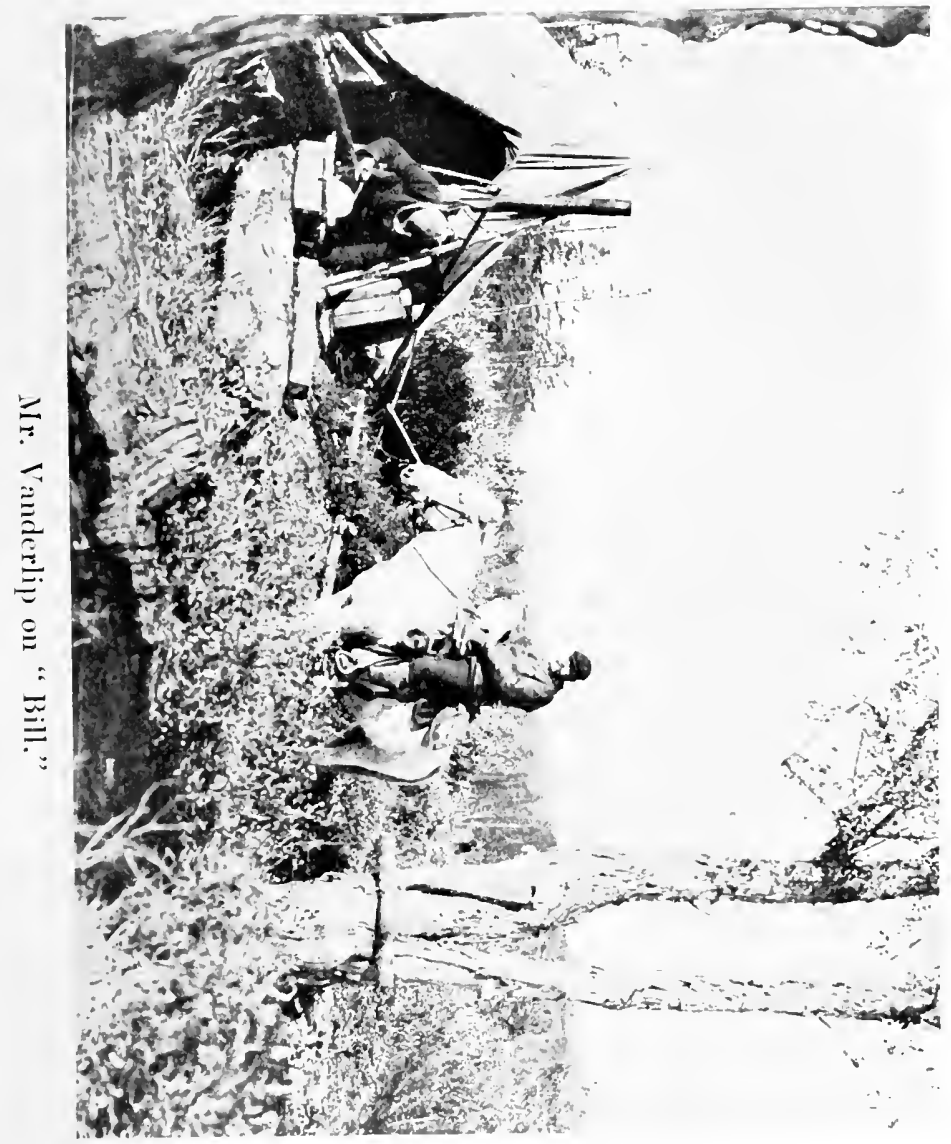



That night as $\mathrm{Kim}$ and $\mathrm{I}$ sat beside a roaring fire of birch logs a little animal leaped suddenly into the firelight opposite. It was a young arctic fox, the prettiest sight I have ever seen. He would jump to one side and then the other, and crouch, and strike attitudes like a kitten at play. Then he would lift his nose in the air and sniff this way and that, raising one of his paws meanwhile. The thought of killing the little thing would never have entered my head if Kim, the matter-of-fact, had not whispered, "Strelite," which means "shoot." Instinctively my hand crept toward my gun, but the little fox saw the movement and was gone like a flash. I was heartily glad of it, too.

In this district are to be found almost all the different varieties of foxes-the red, fiery, blue, chestnut, black, and white. But it should be remembered that, with the exception of the white and red, these are not exactly different species. For instance, a black fox may be found in a litter of the common red fox in any country. He is simply a freak of nature, just as one might find a black kitten among a litter of gray ones. The foxes are caught by poison or traps. There are two kinds of traps, one of which seizes the animal by a leg or around the neck, and the other is made with a bow and arrow so set that as the fox goes along the path the slightest touch of the foot 
will discharge the arrow. Formerly these animals were so common that when the dogs were fed the foxes would come and try to steal part of the food, and had to be driven away with clubs. At that time the natives valued their pelts hardly more than dogskins, but as the foreign demand increased the foxes became worth catching.

We had four days of hard work traveling across the tundra, which was frozen hard in the morning, but was soft in the afternoon. Many times a day we were up to the waist in the mud and water, working to get Bill out of the mire. On the fourth day, just as night fell, we struck the trail between Ghijiga and old Chrisoffsky's little hamlet. I did not know just how far we were from the village, and as we were tired out we camped for the night. In the morning, what was our chagrin to find that we were within a quarter of a mile of Ghijiga. Bill doubtless knew, and if he could have talked he would have saved us one night in the open.

The days now grew rapidly colder, with flurries of snow that heralded the coming of winter. As it was now possible to use dog-sleds, I engaged some of the natives to go to the Korak village and bring down my camping outfit, which I thought must long since have arrived at that place. At this season the dogs could travel only at night, when the ground was hard, but even so 
they covered between thirty and forty miles a day without difficulty.

Meanwhile I loaded up Bill with all he could carry, and, in company with Kim, started out to find the head waters of the Turumcha River, where gold was reported to have been discovered. This trail led west from Ghijiga, but it was first necessary to go up the valley of the Ghijiga a short distance before crossing over into the other valley. I had, therefore, to pass Chrisoffsky's place again. We arrived there the first evening and received a hearty welcome. I tried to get the old gentleman to go with me and to furnish horses and dogs, but he could do neither. His dogs were engaged by the trading company on the coast, and his horses were in too poor a condition to undertake the journey which I contemplated. So I was reduced to the melancholy necessity of walking, Bill carrying our camp outfit.

As I was about to start, a native Tunguse arrived at Chrisoffsky's. He was the first of that tribe that I had seen. Chrisoffsky told me that this young man was going the same road as $I$, and that his yourta, or hut, was near the stream along which I intended to prospect. $\mathrm{He}$ willingly agreed to act as my guide at a wage of one brick of tea a day. He answered to the euphonious name of Fronyo. He was five feet high and weighed only one hundred and ten pounds, but 
was prodigiously strong and wiry. He was dressed in old tanned buckskin, with a gaudy apron trimmed with beads in geometric patterns and with a fringe. According to the custom of his tribe, he wore a long, ugly knife strapped to his thigh, the point reaching to the knee, while the handle lay at the hip. These knives are fashjoned by the Koraks, who sell them to the Tunguses. On his feet were moccasins with seal-hide soles.

I found that he could speak a little broken Russian, and as I had acquired a few Russian expressions we got along famously. So we set out, Fronyo leading off with his long bear spear but no fire-arms. It was a straight three days' trip across the tundra, and without special incident. At night we arrived in good season at a skin yourta on the banks of a tributary of the Ghijiga. On our approach a dozen dogs rushed out with the full intention of tearing us to pieces, but changed their minds when they found that we were equally determined to defend ourselves. The dogs were followed by the denizens of the place, ten or twelve in number, including Fronyo's father, mother, brothers, and sisters.

Their greeting consisted in grasping right hands, throwing out the lips as far as possible and touching the two cheeks and lips of the friend. I pretended ignorance of the ceremony. In truth, 


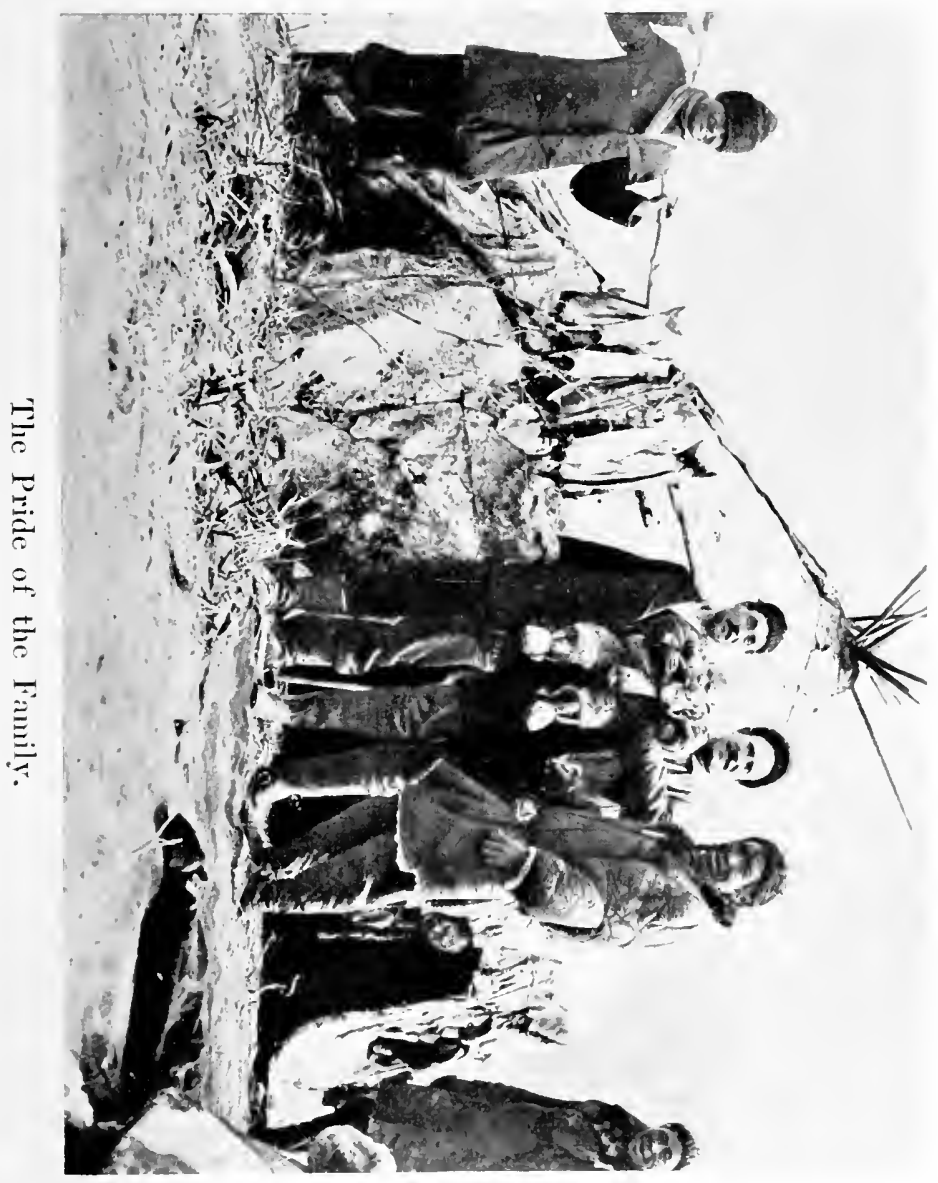


they were so unconscionably dirty that it was impossible to tell the color of their skin, and besides, I could not distinguish the men from the women. But I learned later that the dress of the two sexes does differ slightly, for the women have a little fringe about the bottom of the skirt, which is split up the back precisely like our frock-coats.

The flap of the tent was drawn aside and we crept in, only to find ourselves buried in a dense cloud of smoke, which came from an open fire burning in the middle of the tent, and which escaped through a hole at the top, as in the wigwam of the North American Indian. On sitting down, I discovered that near the ground the air was comparatively clear. Because of this smoke, the natives suffer severely from sore eyes.

Among the Tunguses the guest is always supposed to provide the tea, so I had Kim bring out a brick, and it was brewed and served with bread and sugar. For supper I had a splendid salmontrout spitted before the fire, and it seemed the most delicious morsel I had ever tasted. Then we lighted our pipes and took our ease. I noticed that the women carried pipes. The little brass pipe-bowls are bought from the Russian traders and are fitted with reed stems about eight inches long. Some of the pipe-stems were made of two pieces of wood grooved down the center and then bound together with deer thong. They mix 
Manchu tobacco with the dried inner bark of the fir tree.

When it came time to retire, several logs were added to the fire in the center of the tent, the deerskins were spread, and each lay down in the clothes he or she had worn all day. The tent was twelve feet in diameter, and in that space twenty-two persons slept; three of them were infants who were swung from the top and just below the smoke line. Indeed we lay like matches in a box, and certain grave misgivings $\boldsymbol{I}$ had relative to living mementoes of the occasion were later verified.

But before retiring $I$ witnessed a scene that would have put to shame not a few of the homes in America. These Tunguses are, many of them, adherents of the Greek Church. There was an icon in the tent, and before and after eating they crossed themselves before it. Now as we were about to retire the family shook hands and kissed one another. They came and shook my hand and said, "Pleasant sleep." Then the old man turned his face upward, closed his eyes and said, " $O$ God, do not forget our home to-night." Considering the surroundings, it was the most impressive thing I had ever witnessed.

On our departure the next day we made the old people happy with the gift of several bricks of tea. Snow had fallen during the night to the 
depth of six inches. Winter was on us in full force. As we left we were followed from the yourta by a beautiful black dog the size of a fox. I was to become well acquainted with him later. We camped that night on the banks of the 'Turumcha where I was to commence my work. The stream was only sixty feet wide, but it was swift and turgid and filled with floating ice.

The next morning we were obliged to ford it; so, tying a lariat about Bill's neck and leaving the end of it in Kim's hands, I mounted and forced the horse into the water. At the deepest point it came well up to his shoulders and he found it hard to keep his feet, but we got safely over. Kim pulled the horse back by the lariat and the guide came across. That long-suffering brute had to make four round trips before we and our effects were all across the river. When Kim started across, the dog began to howl piteously, but finally sprang into the water after us. When in mid-stream he encountered a floating cake of ice. He climbed upon it and was whirled downstream and out of sight. He got across, however, and caught up with us two hours later.

We followed up the bed of the stream, stopping often to examine it for signs of gold. We sunk shafts here and there and panned the gravel in the icy water of the stream, always getting a few " colors" but nothing of particular interest. 
Each night we camped in some sheltered nook, often in heavy timber, and our first move always was to change our wet boots. One night I spread out my deerskin bed, put on my heavy fur coat and cap, lay down as usual with the canvas tarpaulin over all, and was soon asleep. About four o'clock in the morning I felt something warm moving at my side. I put out my hand and found that it was the black dog which had followed us. We called him Howka. When I stirred he offered to leave, but I patted him and coaxed him to remain, which he was quite willing to do. Afterward I bought him, and for a year he was my constant companion. Once, during a long period of semi-starvation, he saved my life by hunting sea-gulls' nests, from which I took the eggs.

After working my way up to the headwaters of the stream without finding gold in paying quantities, I determined to cross over the divide into another section, but my guide, Fronyo, begged me to go one day's trip farther up the little brook to a place which he described as "white walls with little sparkling points like the stars." I said to myself, " Probably quartz with sulphurets" (bistlphide of iron). So on we went and came at last to the shiny wall. It proved to be a large vein of low grade gold ore crossing the brook at right angles. Panning below I 


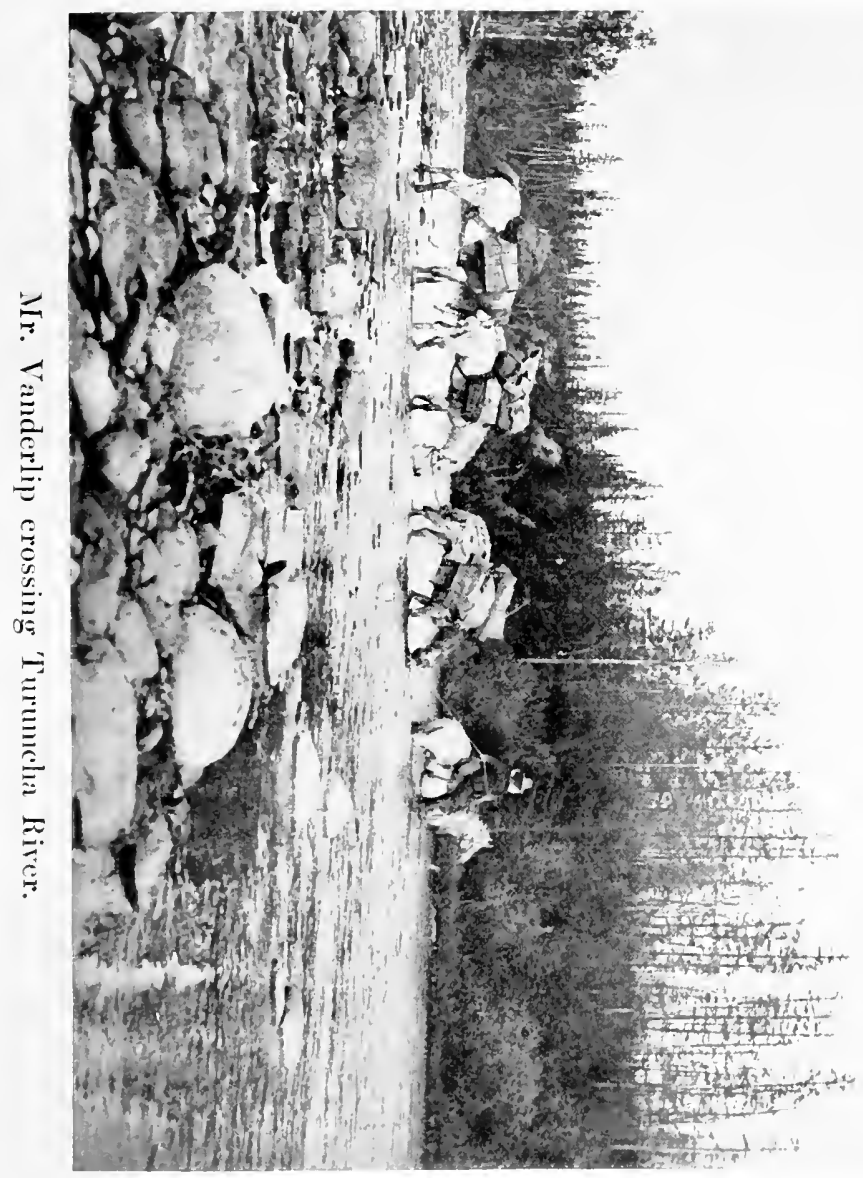



found nothing of particular value; so breaking off fragments of the rocks we piled them up beside the stream, making a little monument to mark the spot, should I wish to revisit it. I appeared to be now in a mineral country. We went on up the brook, panning continually, but nowhere on the bed-rock found gold in paying quantities.

We had now reached the top of the divide, and so crossed over into a district called Toloffka, with a stream of the same name, where we spent several days. The cold was intense. The thermometer registered ten degrees below zero. The streams were all ice-bound, except where they were very swift. The snow was about a foot deep, and Bill was faring badly. His only food was the tops of the grass that stuck up through the snow or that could be found on wind-swept places. He was so weak that he could only pack sixty pounds, and that with difficulty. All our food was gone except rice and tea. Our tobaceo had long ago given out, and, as a substitute, we used brick tea mixed with pine bark. It made a smoke-and that was all. The rough work had destroyed my boots. I had used one pair to mend the soles of the other. My guide made a needle of a fish bone, and with thread from the fiber of a vine sewed the soles on for me. It was evidently time for us to be turning our faces home6 
ward. We went straight for the yourta where Fronyo's family lived, and of course made it in far less time than it had taken us to come. I found that the whole trip had covered just one month. Bill came very near giving out on the home trip, but by a heroic effort pulled through and was rewarded at the journey's end by getting all the provender he could stow away.

As Bill had to carry the pack and as my feet were not in the best condition, Fronyo proposed that I ride to Ghijiga on a reindeer. A fine big bull of about five hundred pounds was brought out and I looked him over. I had some misgivings, but at last decided to accept the offer. The saddle was made with reindeer bones for a foundation. These were securely bound together, padded with moss, and covered with rawhide. The antlers of the deer had a spread of five feet, and there were so many prongs that $I$ never tried to count them. Much to my surprise, I found that the motion of my steed was a smooth and gliding one, even more comfortable than the gait of a single-footer. It had taken us three days to walk up from Chrisoffsky's to the yourta. It took just eight hours to make the same trip in the other direction.

Chrisoffsky's house was on the left bank of the stream, while we were on the right. It would have been death to the deer to have taken him 
within scent of the dogs. So I dismounted two miles from the house, tethered the deer, and made my way in on foot. The stream was not solidly frozen, so I fired off my gun and brought out the whole settlement. A boat was found, and presently I was seated again at old Chrisoffsky's fireside. 


\section{CHAP'TER VIII}

DOG-SIEDGING AND THF FUR TRADE

Description of the sledge and its seven pairs of dogs-The harness-The useful polka-The start-cff a gymnastic performance for the driver-Methods of steering and avoiding obstructions while going at full speed-Dogtrading en route-Dog-fights are plentiful-Prices of sable and other skins in the native market-The four grades of sables-How they live and what they live onA Russian writer on sable hunting-Days when a native would barter eighteen sable skins for an ax.

COULD not delay here. The sledge-road
to Ghijiga was in fine condition, and, hiring a team of dogs, I started out the next morning on my first sledge-ride. Our team consisted of fourteen big, wolflike sledge-dogs with shaggy coats and erect pointed ears. Some were white, some black, some gray, some red, and some a bluish color. The two leaders were a magnificent pairone red, the other blue. They were all fiercelooking fellows, but $I$ had no difficulty in stroking them, as they like to be petted. The harness consisted of a breast collar and a belly-band. Leading back from the collar, and held in place on the 
sides by the belly-band, are two thongs, which are attached to a ring directly behind the dog. From this ring a single thong, three feet in length, attaches the dog to the central tug which draws the sledge. Each thong is fastened to a ring on the tug by means of a wooden pin three inches long. The dogs are always fastened to the tug in pairs. The central tug leads forward from the sledge to a point between the leading pair of dogs. Between the several pairs is a clear space of about eighteen inches.

The sledge itself, which is called a narta, is a remarkable vehicle. It is made of light basswood without nails or screws. 'The parts are bound together with walrus thongs. It is admirably adapted to survive the hard knocks which it is sure to receive. It has just the necessary amount of " give" without losing anything in strength. The runners are from ten to fourteen feet long and two feet apart. They are from three to four inches wide and unshod. The bed of the sledge is raised ten inches above the runners by means of posts at frequent intervals. On each side is a railing six inches high, with a thong mesh to prevent the load from falling off. At about one third the distance from the front to the back of the sledge is placed a perpendicular bow of stout wood, which rises some four feet and a half from the ground. The driver sits behind this, and 
whenever an obstruction is met with, he steps off quickly at the side and pulls the sledge one way or the other by means of this bow, which he grasps in the right hand. The driver holds a stout steelshod stick five feet in length with a cord attached to the end. He can use this polka as a brake by putting it between the runners and digging it into the ground, or he can anchor the sledge with it by driving it perpendicularly into the snow immediately in front of the sledge and then tying the cord to the bow which has been described. When this is done the sledge cannot possibly move forward.

Several bearskins were laid in the bed of the sledge for me, and a back-rest was made by lashing together three cross-pieces. I was told to keep as far down as possible, as it would lessen the probability of capsizing. Before starting, one more important piece of work had to be performed. Chrisoffsky, using the polka as a lever, tipped the sledge up at an angle of forty-five degrees, exposing the bottom of one runner, and proceeded to scrape it with a knife he always carried in a sheath at his thigh. Then from under his fur coat he drew out a little bottle of water which was fastened about his neck with a cord, and wetting a piece of deer fur as one would wet a sponge, he drew it rapidly along the runner, with the result that a thin film of ice was formed along 


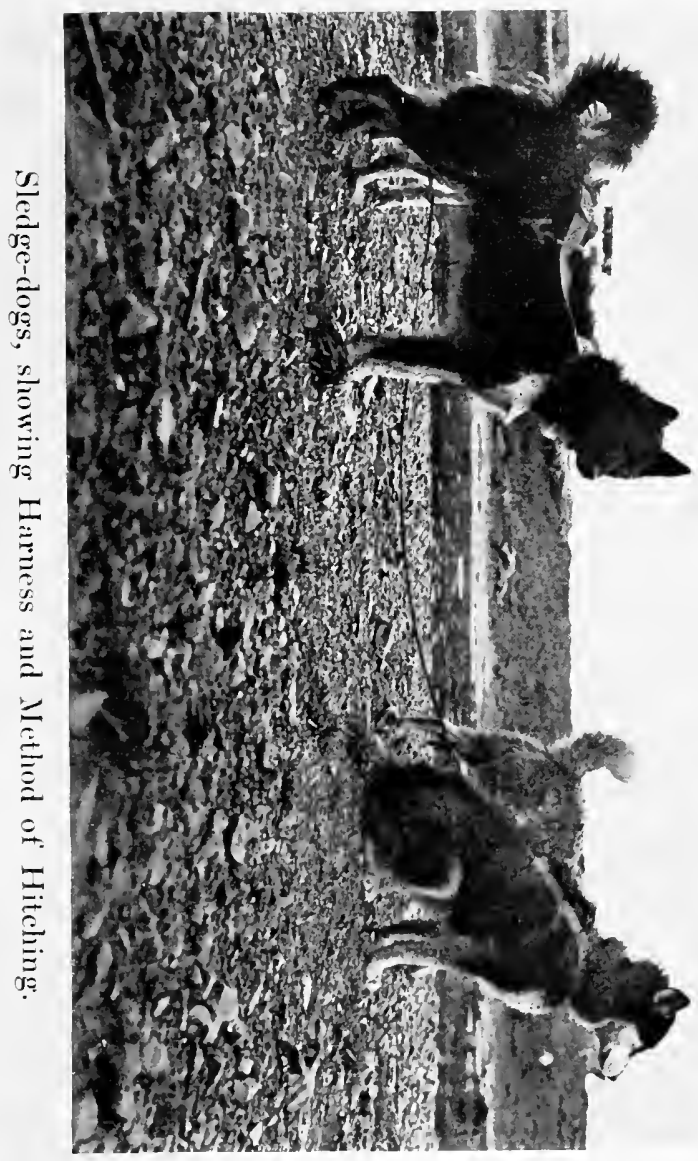



its whole length. The other runner was treated likewise. This is a very important part of the preparation for a sledge-ride.

While this was going on the dogs were continually yelping with excitement and leaping in their collars, eager to be off. Old Chrisoffsky quieted them with the cry " Chy, chy, chy." The old gentleman himself was to be my driver, and I mounted and was carefully tucked in by kindly, even if dirty, hands, while Chrisoffsky restrained the dogs. I said good-by, and settled back to witness a marvelous feat of human dexterity on the part of the driver, and of almost human intelligence on the part of the dogs. It was a crisp, cold morning. The road was well broken, but the difficulty was in getting out of the village with its narrow, winding paths to the open tundra where the road was straight and easy.

As Chrisoffsky untied the cord from the bow, the alert dogs gave a wild yell, and strained at their collars as though they had gone mad. He drew out the polka, placed onc foot on the runner, gave the bow a jerk to dislodge the sledge from its position in the snow, and shouted, "Hyuk, hyuk, hyuk!" to the impatient dogs. They sprang forward together, giving the sledge a jerk that nearly threw me orerboard, and dashed forward at a terrific speed, Chrisoffsky still standing on the rumner and waving the polka 
in his hand. We were off like a shot amid the laughter and good-bys of Chrisoff sky's numerous progeny. The trick was to get the dogs around those sharp curves at such a speed without upsetting the sledge. The driver by shouting, " Put, put, put!" could make them swerve about forty-five degrees to the right, and they would continue to turn till he stopped; then they would go straight ahead. If he wanted them to turn to the left he would give a strong guttural, scraping noise that sounded like an intensified German " ch," repeated as long as he wished them to continue turning. If we met an obstruction he would leap off, even when going at full speed, and by means of the bow pull or push the sledge free from the impending smash, and then leap on again as nimbly as a cat, despite his sixty-odd years. As we swept out of the village, followed by the shouts of "Doswi dania" (goodby), we plunged down into a gully and up the other side on to the open tundra, the dogs on the dead run. For a time our speed must have been nearly that of a greyhound at full stretch. Old Chrisoffsky looked back at me and laughed, and asked me how I liked it.

I have ridden a good many kinds of vehicles, but for beauty of motion give me a narta with fourteen big, wild dogs, and a smooth road. The narta goes like a snake, it is so sinuous and adapts 


\section{SIBERIAN KLONDIKE}

itself so perfectly to the irregularities of the road.

After a while the dogs got the "wire edge" worked off their enthusiasm and settled down to a good steady trot that took us along at the rate of seven miles an hour. They worked together as smoothly as a machine. When they became thirsty, they would lap up the snow beside the path. If one of the dogs stops drawing and begins to shirk, the driver stands up and throws the polka at him, hitting him on the head or back, and then, by a dexterous motion, pushes the narta to one side and recovers the polka as the sledge passes it. The dog so warned will probably go miles with his head over his shoulder watching to see if he is going to be struck again; and all the other dogs, too, keep a weather-eye open. The best dogs are always in the lead, and the poorest ones back near the driver, where he can manage them most easily.

If a dog refuses to draw, the sledge is stopped and the driver, to an accompaniment of very choice language, beats the sluggard with the lash of the polka till he deems the punishment sufficient. That dog will need no more reminders for a day at least. Almost always after starting out one or two dogs have to be handled in this manner before they will settle down to the day's work. Not infrequently dog-teams, meeting in the road, 
will stop and the drivers will proceed to "swap horses," or rather dogs, in the true David Harum style. But the two leaders are never exchanged in this way. They are the driver's favorites, and are too valuable to risk in such a trade. Even if their master is starving he will not part with his leaders.

About five miles out, we met a team of dogs going up-country. We stopped simultaneously to exchange news, and inside of ten seconds one of our dogs made a jump at one of the other team. This was the signal, and in an instant all the twenty-eight dogs were at it tooth and nail in one grand scrimmage. After beating them unmercifully, the drivers were able to separate the two teams, and we found that three of our dogs were limping. I then learned that in a fight the Siberian dog does not make for his antagonist's throat, but for his feet, for he seems to know that injury to that member is the most serious that can happen to a sledge-dog. It was amusing to see with what deftness they would draw their feet back from the snap of the enemy. The neck is generally covered with a thick growth of hair which is impervious to teeth, while from the ankle to the foot the hair is cut away by the driver to prevent the snow from balling upon it. Our troubles proved not to be serious, and at the end of the third hour we approached Ghijiga. As 


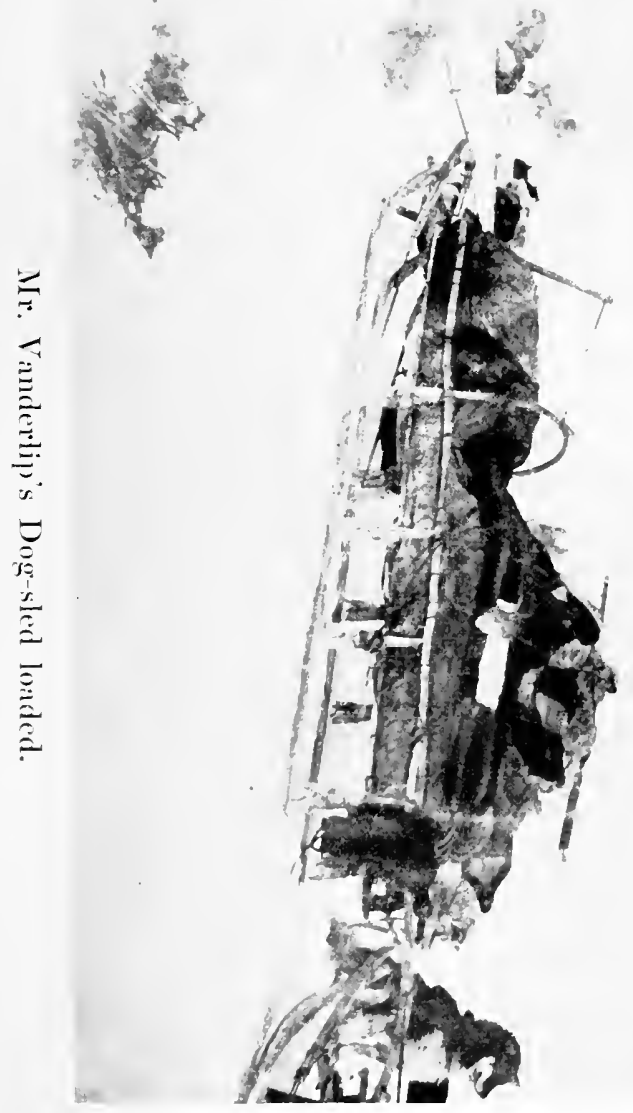



soon as the dogs scented the town they gave a simultaneous yelp and broke into a swift run, as is always their custom in approaching any settlement. At the same time all the dogs of the village, apparently, came rushing out to meet us, and ran alongside yelping and snapping in a friendly way at our dogs. Old Chrisoffsky drew up with a flourish before my cabin, where I received a hearty welcome from the townsfolk. This day's trip from Chrisoffsky's house by dogsledge cost me the enormous sum of one rouble, or fifty cents in United States gold.

It was now late in October, and it was necessary for me to stop in Ghijiga while my winter outfit of clothes was being prepared. The snow was already deep and the river frozen solid, excepting at the rapids. But cold as it was, my work was but just beginning, for it is only in winter that long distance travel is possible. In summer you may struggle across six or eight miles of spongy tundra a day, but in winter you can easily cover from sixty to ninety miles, depending upon the quality of your teams and the number of your relays.

By this time the natives were beginning to bring in their furs and other valuables to exchange with the merchants of the trading company. It may be of interest to give the prevailing prices. 
The native, ordinarily, does not take money for his skins, but various kinds of necessaries. Reducing it all, however, to a monetary basis, we find that he receives for sable skin ten to thirteen roubles; red-fox skin, two to three roubles; white-fox skin, one and a half roubles; blackfox skin, fifty to one hundred and fifty roubles; blue-squirrel skin, thirty-five cents; unborn-deer skin, twelve cents; turbogan (kind of coon), fifteen cents; yearling-deer skin, seventy-five cents; sea-dog skin, one rouble; black-bear skin, seven roubles; brown-bear skin, five roubles; white-bear skin, twenty-five roubles; walrus rope, two cents a yard; walrus ivory, from five cents to one and a half roubles a tusk; mammoth tusk, five to six roubles; fur coats, one and a half to five roubles; boots, twenty-five cents to seventy-five cents a pair. For an ermine skin he is wont to receive two needles or a piece of sugar as large as a thimble.

In exchange for these commodities the traders give tea, sugar, powder, lead, cartridges, tobacco, bar iron one inch wide by a quarter of an inch thick, needles, beads, and various other trinkets.

When the goods are marketed it is found that the company makes anywhere from one hundred to one thousand per cent. profit. Tea, the article most called for, allows only one hundred per cent. profit. On sugar some three hundred per cent. is 


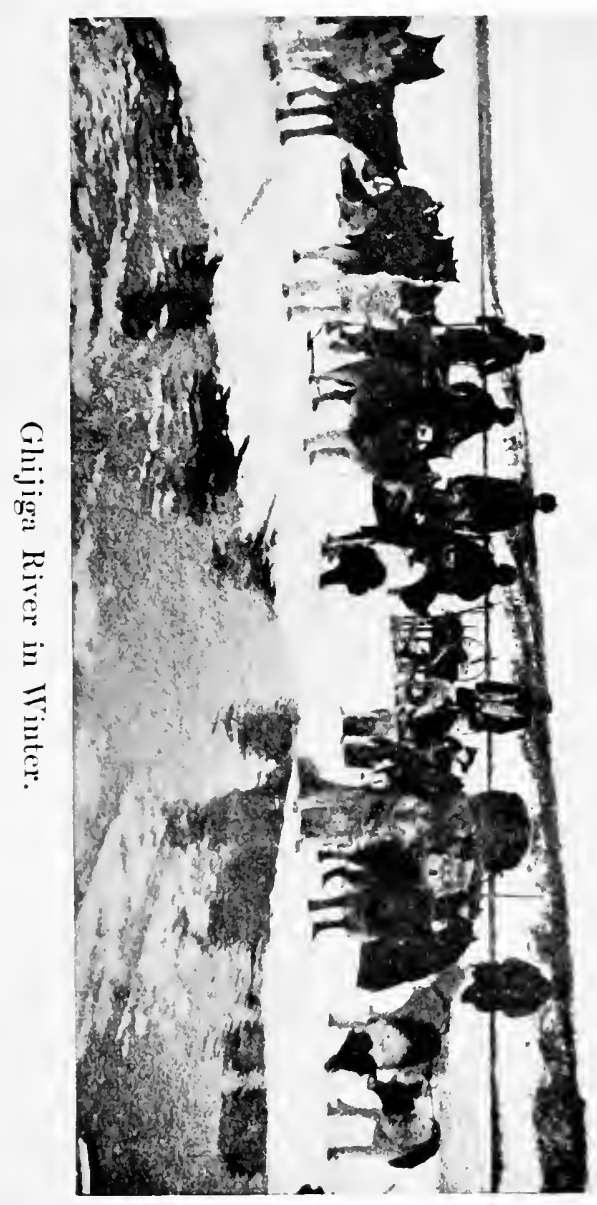



made, and on the trinkets and other miscellaneous goods anywhere from five hundred to one thousand per cent. is made.

Several significant facts are to be deduced from this list: first, the low price that is paid for sables compared with the prices they bring in the European market; second, the comparatively high price the skin of the black fox brings, although it is only a fraction of what it costs at home (a single skin has brought as high as four thousand dollars in Paris) ; third, the extremely low cost of ermine; and fourth, the fact that there is no active trade in mammoth tusks, although they are plentiful. They are often ten feet in length, and it might be supposed that they would contain ivory enough to make them worth much more than they bring; but the fact is that it is fossil ivory, and the outside of each tusk is so far broken and decayed that only the very center of the tusk contains marketable ivory.

The common rule is to give the natives one year's credit; the tea, sugar, tobacco, and other articles which they receive this year being paid for by the skins which they bring next year. The plan works well, for the natives are scrupulous in the payment of their debts. And furthermore, the traders, being on the spot, have a wide personal acquaintance among the natives and know just whom they can depend upon. 
Of course the most valuable portion of the produce of this north country is sable skins. There are four kinds, or rather grades, of sables. The finest come from the Lena River district; the second grade from the territory of which we are writing and within a radius of five hundred miles about the head of the Okhotsk Sea; the third grade from the Amur River district, and the fourth from Manchuria. Generally, the farther north one goes the better the sables.

Before Siberia was conquered by Russia, sables were extremely common, but gradually they were pushed back by the coming of settlers, for they will not remain in the vicinity of human dwellings. They live in holes, as do the martens or ermines, but those who have studied their habits say that they frequently build nests of sticks and grass in the branches of trees, and use them alternately with their holes. They usually sleep about half the day, and roam about in search of food the other half. In the early spring they live on hares, though they will also eat weasles or ermine. When the berries are in season they subsist solely on cranberries, blueberries, and especially the berries of the shad-bush. The natives say that eating these last causes them to itch and rub themselves against the trees, which for the time being spoils their fur; so that while the shad-bush is in berry. no sables are caught. 
About the end of March the sable brings forth its young, from three to five in the litter, and suckles them from four to six weeks.

The method of trapping sables has been well described by a quaint writer near the beginning of the nineteenth century, and, as there have been very few changes during the interval, he is worth quoting:

The sable hunters, whether Russian or native, begin to set out for hunting about the beginning of September. Some Russians go themselves, and others hire people to hunt for them, giving them proper clothes and instruments for hunting, and provisions for the time of their being out. When they return from the chase they give their masters all the game, and restore them likewise all that they received, except the provisions.

A company that agrees to hunt together assembles from six to forty men, though formerly there were sometimes even fifty. They provide a small boat for every three or four men, which they cover over; and take with them such persons as understand the language of the people among whom they go to hunt, and likewise the places properest for hunting. These persons they maintain at the public charge, and give them, besides, an equal share of the game.

In these boats every hunter lays thirty poods of ryeflour, one pood ${ }^{1}$ of wheat-flour, one pood of salt, and a quarter of a pood of groats. Every two men must have

1 Russian weight equivalent to thirty-six pounds avoirdupois. 
a net, a dog, and several poods of provisions for the dog, a bed and covering, a vessel for prcparing their bread, and a vessel to hold leaven. They carry with them very. few firearms.

The boats are then drawn up-stream as far as they can go, where the hunters build for themselves. Here they all assemble and live until the river is frozen over. In the mean time they choose for their chief leader one who has been oftenest upon thesc expeditions; and to his orders they profess an entire obedience. He divides the company into several small parties, and names a leader to each, except his own, which he himself directs; he also appoints the places where each party is to hunt. As soon as the season begins, this division into small parties is unalterable, even though the whole company consists of only eight or nine, for they never all go toward the same place. When their leaders have given them their orders, every small company digs pits upon the road by which they must go. In these pits they lay up for every two men three bags $o^{\circ}$ flour against their return, when they shall have consumed all their other provisions; and whatever they have left in the huts they are obliged to hide also in pits, lest the wild inhabitants should steal it.

As soon as the rivers are frozen over and the season is proper for the sable hunting, the chief of the leaders calls all the huntsmen into the hut, and, having prayed to God, gives orders to every chief of each small company, and despatches them the same road which was before assigned them. Then the leader sets out one day before the rest to provide lodging-places for them. 
When the chief leader despatches the under-leaders he gives them several orders; one of which is that each should build his first lodging in honor of some church, which he names, and the other lodgings to some such saint whose image he has with him, and that the first sable they catch should be laid aside in the quarter of the church, and at their return be presented to it. These sables they call "God's Sables," or the church's. The first sable that is caught in the quarter of each saint is given to the person who brought the image of that saint with him.

On their march they support themselves with a wooden crutch about four feet long; upon the end of which they put a cow's horn, to keep it from being split by the icc, and a little above they bind it around with thongs to keep it from sinking too deep in the snow. The upper part is broad like a spade, and serves to shovel away the snow or to take it up and put it into their kettles, for they must use snow, as they have frequently no water. The principal chief having sent out the small parties, starts with his own. When they come to the places of lodging they build little huts of logs, and bank them up with snow round about. They hew several trees upon the road, that they may the more easily find their way in the winter. Near every quarter they prepare their trappits, each of which is surrounded with sharp stakes, about six or seven feet high, and about four fcet distant, and is covered over with boards to prevent the snow from falling in. The entrance through the stakes is narrow, and over it a board is hung so nicely that by the least touch of the sables it turns and throws them into the 
trap; and they must absolutely go this way to reach a piece of fish or flesh with which the trap is baited. The hunters stay in a station till they have a sufficient number of traps set, every hunter being obliged to make twenty in a day. When they have passed ten of these quarters the leader sends back half of his company to bring up the provisions that were left behind, and with the remainder he advances to build more huts and set more traps.

These carriers must stop at all the lodging-places to see that the traps are in order, and take out any sables they may find in them, and skin them, which none must pretend to do but the chief man of the company.

If the sables are frozen they thaw them out by putting them under the bedclothes with them. When the skins are taken off, all present sit down and are silent, being careful that nothing is hanging on the stakes. The body of the sable is laid upon dried sticks, and these are afterward lighted, the body of the animal smoked, and then buried in the snow or the earth. Often when they apprehend that the Tunguses may meet them and take away their booty, they put the skins into hollow pieces of wood and seal up the ends with snow, which being wetted soon freezes. These they hide in the snow near their huts, and gather them up when they return in a body. When the carriers are come with provisions, then the other half are sent for more; and thus they are employed in hunting, the leader always going before to build traps. When they find few sables in their traps they hunt with nets, which they can only do when they find the fresh tracks of sables in the snow. 'These they 


\section{SIBERIAN KLONDIKE}

follow till it brings them to the hole where the sable has entered; or if they lose it near other holes, they put smoking pieces of rotten wood to them, which generally forces the sable to leave the hole. The hunter at the same time has spread his net, into which the animal usually falls; and for precaution his dog is generally near at hand. Thus the hunter sits and waits sometimes two or three days. They know when the sable falls into the net by the sound of two small bells which are fastened to it. They never put smoky pieces of wood into those holes which have only one opening, for the sable would sooner be smothered than come towards the smoke, in which case it is lost.

When the chief leader and all the hunters are gathered together, then the leaders of the small parties report to the chief how many sables or other beasts their party has killed, and if any of the parties have done anything contrary to his orders and the common laws. These crimes they punish in different ways. Some of the culprits they tie to a stake; others they oblige to ask pardon from every one in the company; a thief they beat severely, and allow him no part of the booty; nay, they even take his own baggage from him and divide it among themselves. They remain in their headquarters until the rivers are free of ice; and after the hunting they spend their time preparing the skins. Then they set out in the boats they came in, and when they get home they give the sables to the several churches to which they promised them; and then, having paid their fur-tax, they sell the rest, dividing equally the money or goods which they receive for them. 
Before Kamchatka was conquered by the Russians the sables were so plentiful that a hunter could easily take seventy or eighty in a season, but they were esteemed more for their flesh than for their fur. At first the natives paid their tribute in sables, and would give eight skins for a knife and eighteen for an ax. 


\section{CHAPTER IX}

OFF FOR THE NORTH-A RUNAWAY

My winter wardrobe of deerskin-Shoes that keep the feet warm when it is sixty degrees below zero-Plemania, a curious native food in tabloid form-Other provisionsOutline of proposed exploration about the sources of the Ghijiga River-Four hours of sun a day-When dog meets deer-A raee for life and a ludicrous dénouement -More queer native dishes-Curious habits of the sledgedog.

I NOW set about preparing my winter wardrobe. With the aid of my good friend Mrs. Braggin, several native women were set at work to make a complete suit of native clothes, for I knew that only in these would I be able to endure the rigors of their arctic winter. The trousers were made of yearling-deer skin tanned soft on the inside, and the short hair left on the outside. A short jacket of the same material completed the inner suit. The socks were made of the same skin with the fur left on the inside. They reached well to the knee. Over these came a pair of boots made from skin taken from reindeer's legs, with soles of seal-hide. A cushion of grass is used in 
the boot. The skin taken from the reindeer's leg is better adapted to the manufacture of boots than any other part of the skin, because the hair is shorter and denser in growth. I also had boots with soles made of the fur which grows between the toes of the reindeer, and which is of such a texture that it prevents slipping on the ice. On each foot of the reindeer there is a tuft of this hair about as large as a silver dollar, and it takes twelve of them to make the sole of a single boot. These boots are used only in extremely cold weather. Even with the thermometer sixty degrees below zero they prevent cold feet.

For an overcoat I had a great koklanka made. It was shaped like a huge night-gown, reaching to the knee. It was made of two thicknesses of yearling-deer skin, and was provided with an ample hood. It is too heavy to wear when walking, but is used in the dog-or deer-sledge and when sleeping. It is usually belted in with a gay-colored woolen scarf. For head-gear I wore a "Nansen" woolen hat capable of being drawn down over the face. Without it my nose would have been severely punished. My heavy. mittens were made of fur from the deer's leg, with the hair outside. Even in the worst of weather they were a complete protection from cold. Of snow-shoes I took three pairs, two being designed for use in soft snow. They mea- 


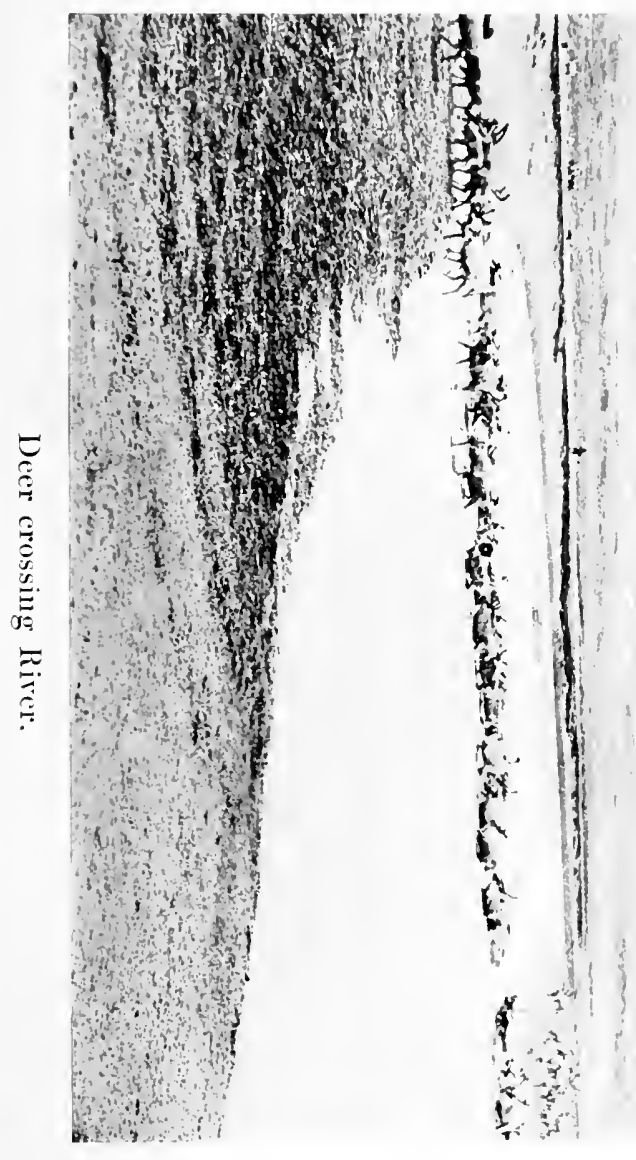



sured five feet and ten inches long by eight inches wide, being pointed and curved up in front and gathered to a point at the back. They were shod with reindeer fur, with the hair pointing back, thus preventing slipping. One pair for use on hard snow were three feet long and eight inches wide.

An indispensable part of my equipment was a sleeping-bag made of the thick winter fur of the reindeer, with the fur inside. It was provided with a hood that, when pulled down, completely shut out the eold. One would suppose that the sleeper must smother in such a case; but, although at first it seemed rather close, I suffered no inconvenience. Enough air found its way in around the edge of the hood for respiration.

For provisions I first laid in several hundred pounds of plemania, as the Russians call it. It consists of little balls of reindeer meat chopped fine, and surrounded with a casing of dough. Each ball was about the size of an English walnut. These froze immediately and remained so till thrown into a pot of boiling water. 'Ten minutes then sufficed to make a most tempting dish. To this I added several hundred pounds of hard rye bread, which had been cut in slices and dried on the top of the oven to the consistency of stone. Tea, sugar, and tobacco were added as luxuries, though the first is well-nigh a necessity, and all 
of them are potent levers in opening the hearts of the native Korak or 'Tunguse. I took a small quantity of dried fruits, which, of course, proved most useful in a land where food is almost all of an animal nature.

It was my intention to explore first the mountains in which the Ghijiga River has its source, together with the tributary streams; and after that to cross over the mountains and explore the head waters of the rivers flowing north into the Arctic Ocean. I anticipated that this would take at least two months.

Old Chrisoffsky furnished six dog-sledges; he himself and two of his sons acted as drivers. The other three drivers were hired from Ghijiga. My party consisted, then, of the following members: my faithful Kim, who stuck to me through thick and thin, though, at first, he little dreamed how far I would take him from the pleasant hills and valleys of his beloved Chosun; my Tunguse guide, Fronyo, who had proved such a valuable help in my trip into his district; the six drivers, myself, and the eighty-four dogs. I had left behind all my Russian help, as they would have been of no value on such an expedition as this.

The reader may imagine that our stock of food was small for such a party, but we were going into a reindeer country where we were sure of securing all the meat we wanted. So all the available space 


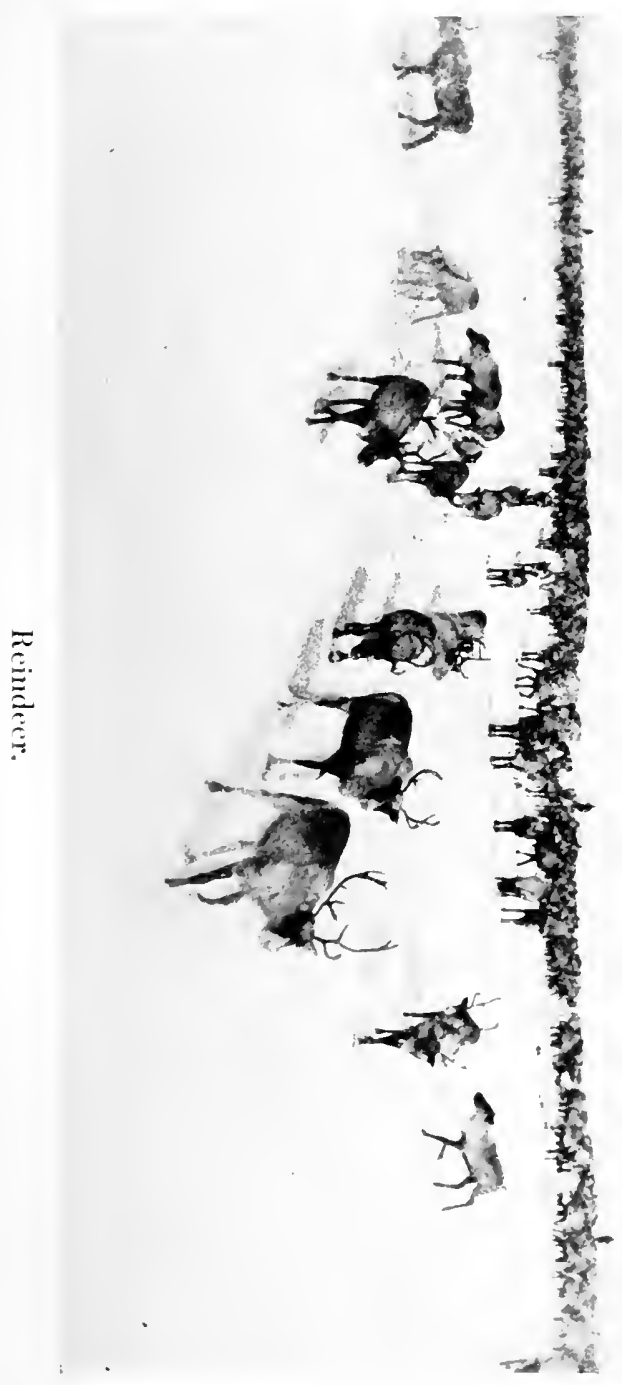


$$
\text { . }
$$ 
on the sledges was loaded with dog-foodnamely, salmon heads and backs. It was now November, and there were only four hours of sunlight-from ten to two. But the northerner does not depend on the sun. The glistening snow and the stars overhead give sufficient light for ordinary travel.

We were off with a dash and a happy howl of mingled dogs and village children, at one in the afternoon, and that night we spent at Chrisoffsky's village. Thenext morning we were off again in the gray light at seven o'clock, up the bed of the Ghijiga River. The third day out we neared the yourta of a wealthy 'Tunguse magistrate. At four o'clock in the afternoon the dogs suddenly broke into a swift run, and we knew they had scented something that interested them. We soon perceived that we had struck a deer trail and that we were nearing an encampment. We turned a bend in the road and there, a hundred yards ahead of us, saw the cause of the dogs' excitement. A team of reindeer were running for their lives. Their 'Tunguse driver was lashing them with the whip and urging them on with all his might, for he knew as well as we that if our dogs overtook them before the camp was reached, we seven men would be utterly powerless to prevent the dogs from tearing the deer to pieces. Chrisoffsky put on the brake with all his might, but it had not 
the least effect. Our fourteen dogs had become wolves in the turn of a hand and no brake could stop them. There were many stumps and other obstructions along our path, and my driver had great difficulty in preventing a smash-up. For a short time the deer held their own, and, in fact, gained on us, but before the yourta came in sight we were gaining rapidly. While we were still at some distance the people of the village, warned by the cries of the dogs, comprehended what was the matter, and, arming themselves with sticks and spears, came running toward us. As they came on they spread out in a fan-like formation across the trail. When the terrified deer reached them they opened and let the team through, and instantly closed again to dispute the passage of our dogs. Chrisoffsky was in no wise minded to let these natives club his dogs and perhaps injure the valuable animals, so he resorted to the last expedient. Giving a shout of warning to me he suddenly, by a deft motion, turned our sledge completely over, landing me in a snow-drift on my head. In this position the sledge was all brake and the dogs were forced to stop, leaping in their harness and yelling like fiends incarnate. I sat up in the snow-bank and laughed. The other drivers had followed our example, and the struggling tangle of sledges, harness, dogs and men formed a scene that to the novice at least 
was highly ludicrous. The drivers and the village people were belaboring the dogs, and the entire herd of reindeer belonging to the village were escaping in all directions up the hills.

When order was at last restored, which was not accomplished till every deer was out of sight, we made our way to the yourta, which was large and comfortable, and, as usual, the women set about making tea. The reader may well ask how the natives can use both dogs and reindeer if the very sight of a deer has such a maddening effect on the dogs. The explanation is simple. The two never go together. There is the dog country and the deer country, and the two do not impinge upon each other. Even among the same tribe there may be a clear division. For instance, there are the "Deer Koraks" and the "Dog Koraks." In some of the villages of the former there may occasionally be seen a few low-bred curs which are not used for sledging and have been trained not to worry deer. Confusion is often unavoidably caused by traveling with dogs through a deer country, but the natives do not take it in ill part, knowing that if they themselves have to travel with deer through a dog country they will cause quite as much inconvenience.

While we were drinking tea and eating hard bread I noted that the settlement contained some 
thirty men, with their wives and children. The women hastened to prepare a dinner of unborndeer's flesh and deer tongues. Frozen marrow bones, uncooked, were broken and the marrow, in the shape of sticks or candles, was passed around as a great delicacy. These dishes, together with frozen cranberries, formed our repast, and a very good one we voted it.

When we were done I went outside and found, to my surprise, that the dogs had not yet been fed. I remonstrated with Chrisoffsky, but he answered that they had not yet finished their evening toilet. Then I saw that the dogs were busy licking themselves and biting the pieces of frozen snow out from between their toes. My driver explained that if they were fed before performing this very necessary task, they would immediately lie down to sleep and wake up in the morning with sore feet and rheumatism, and then they would be useless for several days. It takes the dogs a good hour before they have groomed themselves fit for dinner. They seem to know that they can get nothing to eat before this work is done, but the minute they have finished they sit up and begin to howl for their meal. Each dog receives two or three salmon backs and heads. This is a fairly good amount considering that the salmon were originally eighteen- or twenty-pound fish. The dogs were all left in harness and still attached to 


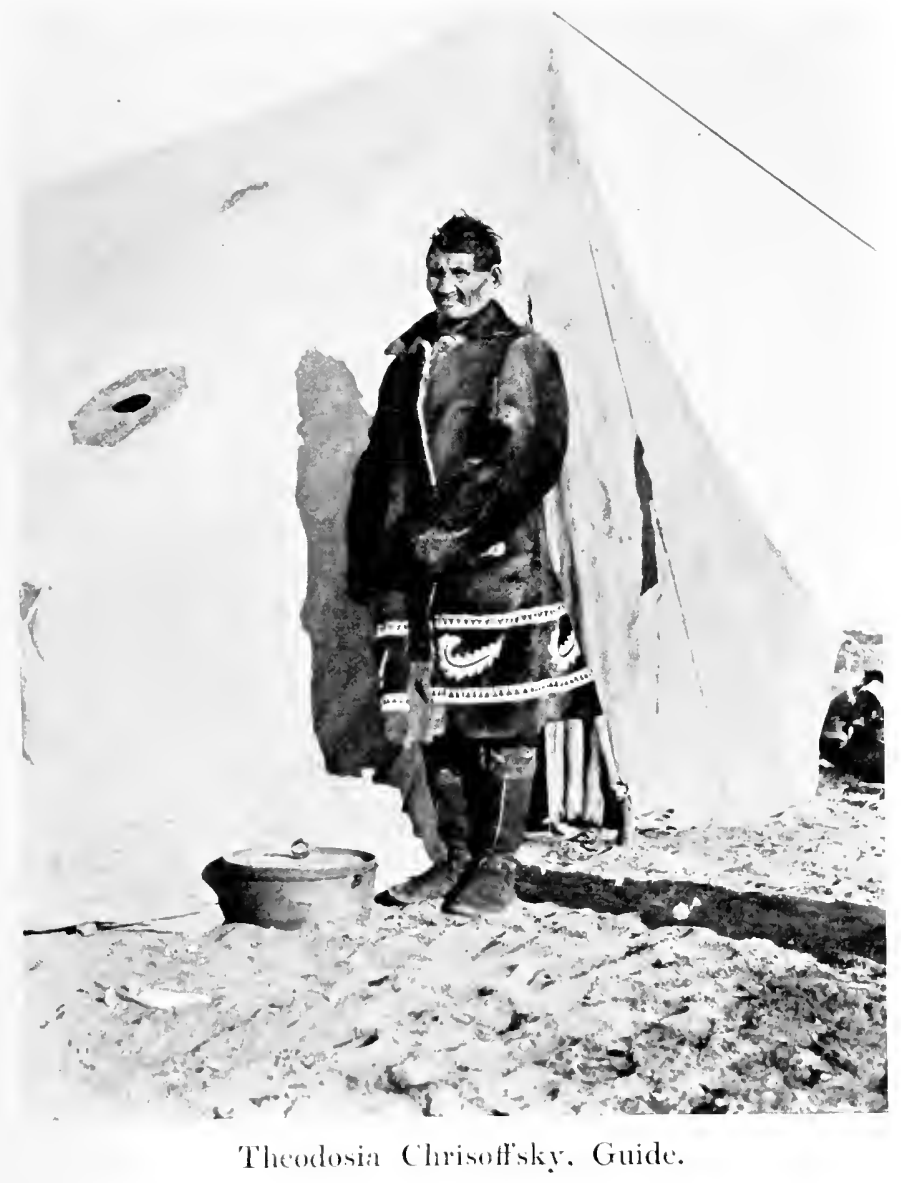



the main tug. This is pulled taut and anchored at the front with the polka, which prevents the dogs from fighting, for no more than two can reach each other at a time. As they feed, the drivers watch them to see that they do not steal each other's food. After they finish their dinner they scratch a shallow place in the snow, curl up with their backs to the wind and go to sleep. They are never unfastened from the sledge from one end of the journey to the other. They literally live in the harness. While the dogs were eating, the mongrel curs belonging to the encampment (an entirely different breed from the sledge-dog) stood around and yelped saucily at the big intruders, but the sledge-dogs gave them no notice whatever.

The dogs sleep quietly all night unless one of them happens to raise his nose and emit a longdrawn howl. At this signal they all join in the howl for about three minutes, stopping at the same instant. If some puppy happens to give an additional yelp, all the others turn a disgusted look at him as if, indeed, he ought to display better manners. 'This howling concert generally comes off two or three times a night. We do not know what causes it, but probably it is some subconscious recollection of their ancestral wolfhood. The same thing happens whenever the team stops on the road. They all sit and howl for several minutes. 
On the road the dogs are fed simply with the dried fish heads and backs; but at home a more elaborate meal is prepared for them. Water is put into a sort of trough, and then rotten fish, which has been kept in pits, is added, with a few of the dried fish, and the whole is cooked by throwing in red-hot stones. This is fed to the dogs only at night. In the summer-time the dogs have to forage for themselves, which they do by digging out tundra-rats. By the time summer is over the dogs are so fat that they have to be tied up and systematically starved till brought into condition for the sledge again. This period is one long concert of howls, but the natives do not seem to mind it. The food of the dogs is entirely carnivorous, for they would rather live by gnawing their own harness than to eat bread, even if the latter could be supplied. The instinct by which these animals foresee the coming of a blizzard is truly wonderful. The unfailing sign of a coming storm is the pawing of the snow. For what reason they paw the snow will probably never be known. This, too, may be some residual taint of their original savage state. 


\section{CHAPTER $\mathbf{X}$}

\section{THROUGH THE DRIFTS}

Sledging over snow four feet deep-Making a camp in the snow-Finding traces of gold-A grand slide down a snow-covered hill-My polka breaks with disastrous results-Prospecting over the Stanovoi range.

$7 \mathrm{HE}$ next morning we had before us ten 1 miles of forest in which the snow lay four feet deep, and the trail was unbroken. This meant serious work for our teams. At the advice of Chrisoffsky I hired two reindeer narties to go ahead and break the trail, but they had to keep a mile in advance, out of sight of our dogs. The snow had been falling all night, and when we came out in the morning, we saw only a lot of little snow hummocks, like baby graves in the snow. Chrisoffsky cried, "Hyuk, hyuk!" and there occurred a most surprising resurrection. Every dog jumped clear of the ground from his warm bed and clamored to be off. I looked to see them fed, but nothing were they to have till their day's work was done. When fed during the day they are lazy and useless, but with the anticipa- 
tion of salmon heads before them they push on heroically. It would be difficult to express adequately my admiration for these animals. They are patient, faithful, and always ready for work.

A mile, then, in the lead went the reindeer narties to break the trail; and ahead of them were two Tunguse villagers on snow-shoes to mark the way for the deer.

A mile in the rear came the dogs, and heavy work it was, as is shown by the fact that when lunch-time came we had made only five miles. When we came up with the Tunguses they had already built a fire, and water was boiling. The deer were tethered in the bushes about two hundred yards away, out of sight of the dogs. The latter smelled them, however, and were making desperate efforts to break out of their harness and give chase, but their efforts seemed futile, so we paid no more attention to them. As we were busy drinking tea I happened to look around, and was dismayed to see that the worst dog in the pack had broken loose and was already near the deer, who were plunging and making desperate efforts to escape. When the dog was almost at the throat of the nearest deer it broke its fastenings and made off through the snow, followed by the rest of the herd. We hurried after them on our snow-shoes at our best speed. The deer could easily outstrip the dog in the deep snow, but we 
年

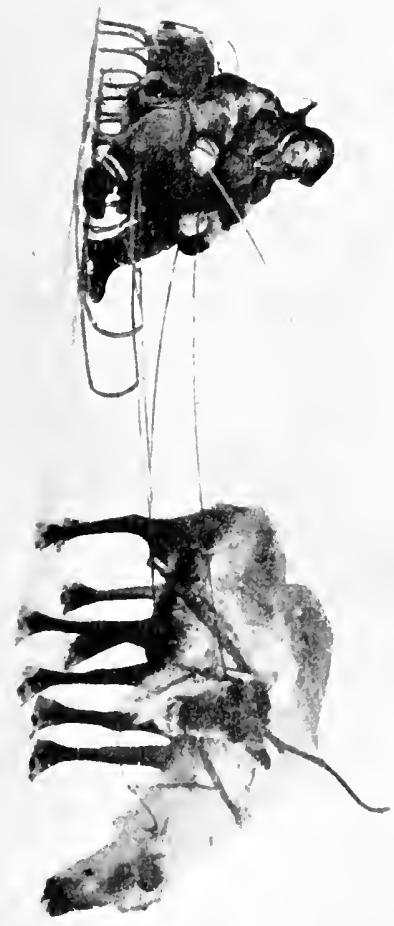



wanted to stop the chase before they were completely frightened away. But we were too late. By the time that we had secured the dog the deer were a mile away, making straight for home, and we knew that nothing could stop them till they found themselves in their own village.

Thus it came about that we had to break our own trail for the balance of the way through the woods. This proved to be extremely difficult. Every man had to put his shoulder to the wheel, or rather to the sledge, and frequently it was necessary to use several teams of dogs on a single sledge, and then return for the other sledge. When night came we found that we had covered nine miles, after an exceedingly hard day's work. We were still a mile from the river, where we were sure to find a good road on the ice.

We had now to prepare for the night. With our snow-shoes for shovels we cleared a space twelve feet square right down to the ground, and built a roaring fire in the center of the cleared spot. The loaded sledges were placed on the banks about the sides, while the dogs lay, as usual, in the snow. Our sleeping-bags were placed about the fire on piles of fir boughs, and after a good supper of reindeer soup, bread, and tea, we lay down and went to sleep. A light snow covered us with a mantle of down, which ensured our warmth. 
When I awoke in the morning and opened my hood, I found two inches of snow over me. That day we floundered through the remaining mile of deep snow to the river. I was pushing one of the sledges, when we came to the steep bank that leads down to the river. The sled began to glide down the declivity, settling deeper and deeper. Chrisoffsky called to me to get on quickly, as there was open water beneath, but he was too late. I was already in the icy water up to my knees. We had unfortunately struck a snow-bridge over open water. The sled was fast in the snow, and the dogs were struggling madly. By vigorous pulling and pushing we managed to get the sledge out on to the ice. The other drivers, who were behind, saw our predicament and went upstream, prodding with their polkas until they found solid ice beneath. Chrisoffsky immediately began taking the lashings off the pack on the sled to get me dry fur socks and boots. Almost before I could undo the lashings, those I wore were frozen stiff. The last one was cut away with a knife. I applied a vigorous rubbing with snow to my feet and they were soon glowing with warmth. Then pulling on the warm, soft fur socks and fresh boots, I found that I had suffered no harm; but Chrisoffsky warned me that whenever I had wet feet I must change immediately or serious consequences would result. 
'At the time, the thermometer stood between ten and fifteen degrees below zero.

On examining the wind-swept bars of the creek there seemed to be good promise of gold, so making camp near timber I prepared for a three or four days' stay. The ground was frozen to bedrock, and it was necessary to thaw it out all the way down. The following day I unloaded the sledges and sent them into the woods under the direction of Chrisoff sky to haul in fuel for the fires. I selected a likely spot and proceeded to thaw out a shaft. As this was very slow work, I determined to try it in several places at the same time. After the fires had burned three hours the picks and shovels would be called into play, and we could take out about twelve or fifteen inches of gravel. The surface gravel showed some small "colors" in the pan, and I determined to set watches and keep the fires going night and day. A windlass was rigged over one of the shafts, and we went down twenty-five feet, till we came to boulders which showed that we were near bedrock. Six inches more brought us to the end. I eagerly panned out some of the gravel and found several tiny nuggets, but was forced to admit that there was not enough gold to pay for working. The other shafts showed the same results; so we were compelled to move on after four days of exhausting and fruitless work. We 
repeated this operation at several other points on the river, and carefully examined the outcroppings all along the stream. Coming to the head of the river, we crossed over the summit of the ridge. The aneroid showed that we were seven thousand six hundred feet above the sea level. When we reached the top, we found that a long, smooth stretch of snow swept down into the valley beyond. For a quarter of a mile the smooth, hard surface was unbroken by bush or stone. I asked Chrisoffsky how it would do to slide down, but he shook his head and replied that it would be dangerous for dogs and sledges alike. I had, however, conceived the foolish notion that it would relieve the monotony of life a little to slide down that incline, and I overpersuaded my driver to make the attempt. Moreover, it would save several miles of travel over a safer but more circuitous route. The dogs were unhitched. Chrisoffsky's two sons took one of the sledges, and, by sticking their heels into the snow, slid about half way down somewhat slowly, then they both climbed on to the sledge, stuck their polkas into the snow for brakes, and "let her go." 'They went the remaining distance like an arrow, and shot out into the plain below triumphantly. They stopped and waved their hands as much as to say, "See how easy it is." Chrisoffsky then sent down one team of dogs, still fastened 


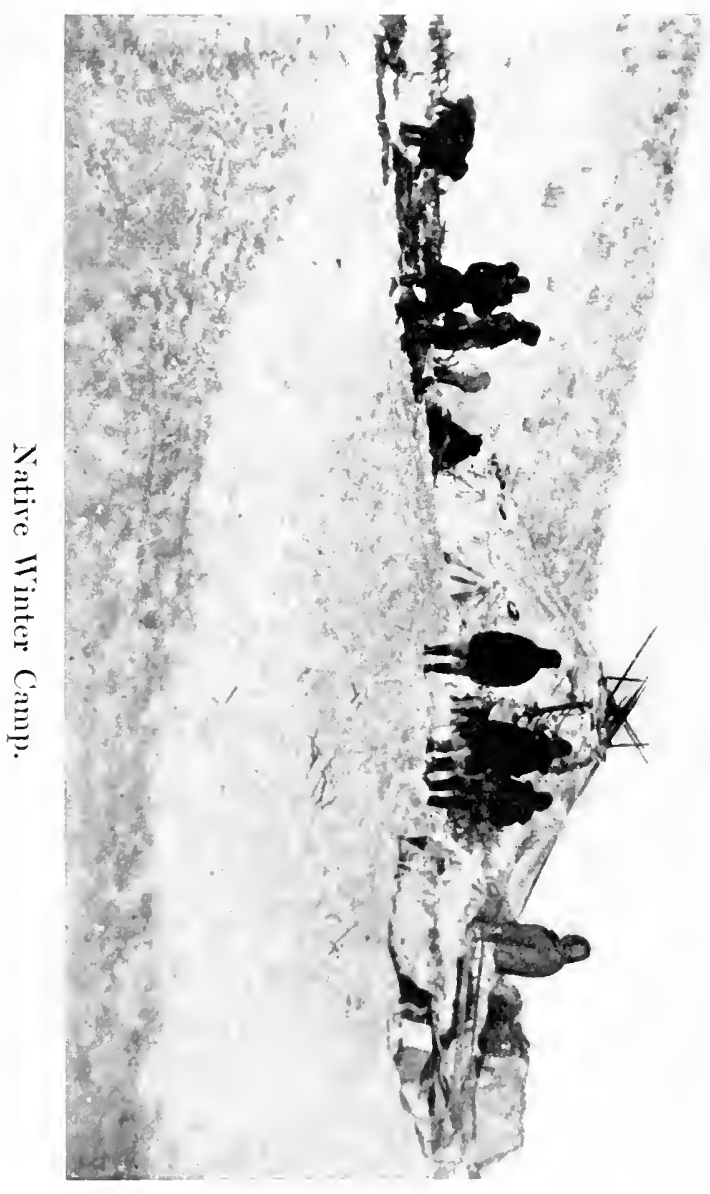


to the tug. This was a mistake, for the leaders went cautiously and the others crowded on them. In an instant they were one howling, wrangling ball of dog-fur rolling down the hill. The natives were all shouting and cursing their liveliest, but I could only hold my sides with laughter. I utterly refused to see the serious side of the adventure. The remaining dogs were sent down two and two. Chrisoffsky and I, with one sled, were the last to go. Sitting on opposite sides of the sledge with our polkas carefully adjusted, we slipped over the brink and shot down the hill. By some perverse chance my polka broke in my hands, the sledge slewed around, and we both went head over heels. I landed on my head some yards from the careening sledge and continued my journey down the hill in a variety of attitudes, all of which were exciting, but none very comfortable. Had I not been so heavily bundled up I could not have escaped serious injury. Old Chrisoffsky and the sledge were a good second in the race, first one and then the other being on top. They held together bravely. When we all rounded up at the bottom and took an inventory of damages, we found that there were no bones broken and that no harm had been done, except to my Winchester rifle, the barrel of which was sprung.

And as the days passed, I continued to busy 
myself examining the outcroppings or digging in the creek beds for signs of gold, until about the middle of December, by which time I had gone over that section of the Stanovoi range pretty thoroughly as far as their southern slopes were concerned. And then I essayed to pass over the lofty range to discover what was on the other side. 


\section{CHAPTER XI}

\section{BURIED IN A BLIZZARD}

A trip to the northern side of the Stanovoi range of mountains-Nijni Kolymsk, the most-feared convict stationSledging by light of the aurora-Lost in a blizzard on the vast tundra-Five days in a snow dugout-I earn a reputation as a wizard-Back at Chrisoffsky's.

TN order to reach the northern side of the 1 Stanovoi range of mountains it was necessary to make use of one of the few passes that are to be found. At an elevation of nine thousand feet, we succeeded in accomplishing the passage, and found ourselves on the head waters of the Kolyma River. The name as given in that locality was more like Killamoo than Kolyma. Due north, far across the wastes of snow, was the town of Nijni Kolymsk, the spot most dreaded by Siberian convicts. This station is used only for the most dangerous political prisoners. About their only occupation is to gather hay and pick berries in summer. Provisions are carried to them in the summer by a man-of-war. None but Russians in authority are ever allowed near the place. The natives could give me very little defi- 
nite information about it. They had strict orders from the magistrate in Ghijiga not to approach this convict station.

We swung to the northeast and east, which course would bring us back to Ghijiga. Wherever it was possible we examined the float rock and sunk shafts to determine whether any of the precious metal was hidden away in the mountains or beneath the waters of the streams. As we came back over the mountains our course lay over the head waters of the Paran River, which runs southeasterly and enters the Okhotsk Sea. We passed over the divide between this and the Ghijiga, and tried to steer a straight course for Chrisoffsky's house. Here we came to a stretch of tundra two hundred miles wide. The snow was hard and the going very good. We struck the trail of a number of " $\mathrm{dog}$ " Koraks who were, evidently, bringing in their furs. The tundra was as level as a floor, and the driving was so easy that it was possible to sit and doze while the dogs sped over the white expanse.

As it was now December the nights were made bright by the light of the aurora, while at noon the sun just shone, a red disk, above the southern horizon. This is the month noted in that region for its severe storms. The days were mostly overcast. The second morning after we had started out across the tundra a light flurry of snow blew 
up. Chrisoffsky shook his head and said it was going to storm. We were just half way across the bare tundra, the worst place possible in which to try to weather one of these storms, because of the utter lack of fire-wood. Chrisoffsky called back to me that he was looking for a porgo, which, in his dialect, means a blizzard. About noon the storm struck us with full force. I was continually standing up in the sledge to catch a sight, if possible, of some trailing pine where we could make an excavation and find fire-wood; but it was all in vain. At last the dogs lost sight of the trail and could follow it only by the sense of smell. When the snow came down so heavily that we could hardly see our leading dogs, we halted to let the others catch up with us. With our snow-shoes we dug down six feet to the ground, making an excavation that was, roughly, eight feet square. Placing the three sledges around the edge of the hole, we banked them in with snow. Then we took a tarpaulin from one of the sledges and with walrus-hide rope improvised a sort of roof over our dug-out. The dogs, after washing themselves, dug holes in the snow and settled down comfortably to sleep. They were almost immediately covered with snow. At this time the thermometer stood thirty-five below zero. We could not tell whether it was actually snowing or whether the snow was 
only being driven by the wind, but at any rate, the air was filled with it and the prospect was anything but exhilarating. We lined the bottom of the hole with furs, got out our sleeping-bags, and prepared for a long siege.

As we were without fuel, we had to eat cold food. Frozen reindeer meat taken raw is not an appetizing dish, but this, together with hard bread and pounded soup-ball, formed our diet for the next few days. As we had but few fish left, the dogs were put on short allowance. In this snowy prison we were held for four mortal days, and were obliged to climb out every three or four hours and relieve the tarpaulin of the weight of snow. Our furs were damp, caused by our breath, which congealed and thawed again from the warmth of the body; to say the very least of it, we were extremely uncomfortable. At last it got so bad that I gave orders to burn one of the sledges, and that day we feasted on hot tea. Our deer meat was all gone, so we stopped feeding the dogs, and appropriated the remaining fish to our own use. The result was that the dogs began gnawing their harness, and had to be chained up with dog-chains which we carried for the purpose. The time spent in orr snow retreat was not entirely lost. To while away the tedious hours I gave my arctic friends some lessons in astronomy, using snowballs as object-lessons. It was not an 
ideal observatory, but there was at least snow enough to have represented all the heavenly bodies, down to fixed stars of the fourteenth magnitude. It all began by their asking how God made the aurora. On the side of our excavation I made a rough bas-relief of the great masonic temple in Chicago. They looked at it very politely, but I could see that they took me for the past master of lying. I told them all about elections, telephones, phonographs, and railroads, and gathered from their expression that they thought I had gone mad from the cold and exposure. They looked at one another and muttered, "Duroc, duroc," which is Russian for crazy.

I also amused myself at their expense by the use of a compass and a little pocket magnet; the latter I palmed and with it made the magnetic needle play all sorts of antics. They asked what made the needle move about continually, and I replied that it would point to any place that $I$ might designate, by simply requesting it to do so. Chrisoffsky, the skeptical, thought he had caught me, for he immediately asked me to make it point toward Ghijiga. Now I happened to know about where Ghijiga lay, for just before the storm came on I had caught a glimpse of a mountain near that town. So I put the compass in my lap, palmed the magnet, and began mut- 
tering and waving my hand over the compass. At the same time I repeated, in sepulchral tones, the magic formula:

\author{
Ere eirie ickery Ann, \\ Fillisy follisy Nicholas John, \\ Queevy quavy English navy, \\ Stickelum stackelum Johniko buck!
}

The hand with the magnet was now in the proper position, and the needle pointed steadily toward Ghijiga. Old Chrisoffsky sat with amazement and fear pictured all over his face. He glanced over his shoulder as if looking for some place to run, and exclaimed in a deep and piteous tone, "Dia Bog!" which means, "O Lord."

After a long silence he asked me if the compass would answer his questions as well. I said I did not know, but that he might try it and see. Concentrating his whole attention upon the compass, he bent over it and tried to imitate my motions, and asked the instrument to tell him the direction in which his house lay. Of course the needle, which, meanwhile, I had been causing to swing about in all directions, now came to a standstill due north, directly away from his house. He looked puzzled and said it must be because he did not understand the wizard formula, and I promised to teach it to him at some future time.

I also performed some other simple tricks, 


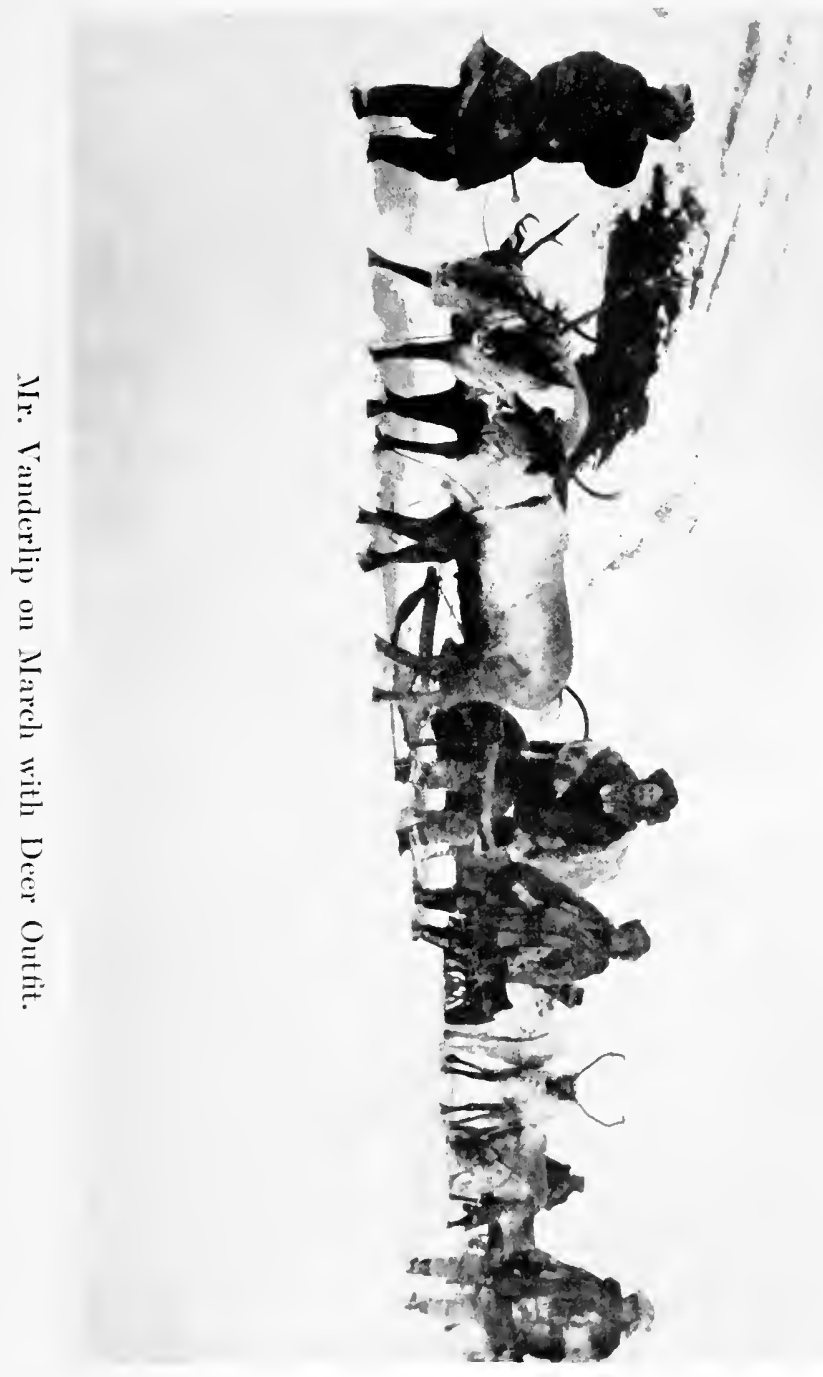


which actually frightened him so that for a time he went out and sat in the snow all alone. I found later that my reputation as a wizard spread through that whole district, and time and time again I had to go over these old tricks before admiring audiences.

During the night of the fifth day the storm passed and the stars came out once more. Our bedraggled party crawled forth from our prison, and harnessed up the weak, but willing, dogs, who seemed to know that we were not far from home; for they tugged at their collars gladly, and we were soon gliding over the snow.

Ten miles from Chrisoffsky's house we came down upon the wind-swept ice of the Chorny Raichka, a tributary of the Ghijiga. From this point the going was ideal. We had timber on both sides, but we did not stop to build a fire. 'The dogs were very weak, yet they displayed wonderful mettle, knowing they were near home. They went so fast that the sledges were continually slewing about on the smooth ice in imminent danger of capsizing; but they were steadied by a clever use of the polka.

While still a mile from Chrisoffsky's, we saw women and children running out to meet us. Because of the storm and the fact that we were two weeks overdue, we knew that there would be anxious mothers and wives in the little village. We 
came in with a flourish, a score of children hanging on the sides of the sledges. We encountered a terrific storm of kisses, which I evaded as best I could. Willing hands unhitched the faithful dogs, and then we all went into the house. The village was warned of our approach while still far away, because each dog carried a little sleighbell on his back. The people had heard the tinkling of the bells sometime before we had come in sight.

To say that we fed off the fat of the land is literally true. Seal fat, deer fat, marrow fat, blubber galore with cranberries, and tea by the gallon. For once I gladly exchanged snow for vermin. Perhaps the greatest comfort was the opportunity to wash my face and hands, which I had not been able to do for seven days. 


\section{CHAPTER XII}

\section{CHRISTMAS-THE " DEER KORAKS"}

I celebrate Christmas day with the over-kind assistance of two hundred natives-Koraks as sharp-shooters-Comic features of a Russian dance-Off for Kaminaw-Another runaway-Slaughtering deer-A curious provision of nature-Eight families in one yourta-Korak method of washing dishes-A herd of ten thousand deer.

WUEN I reached town the Russians desired to know what $I$ had accomplished, and I was obliged to tell them that I had discovered no considerable deposits of gold on the head waters of the Ghijiga.

Some time before this I had caused it to become known that I would pay liberally in tea or other commodities for bags of rock picked up in the beds of streams and delivered in Ghijiga. I now found upward of a ton of such specimens awaiting my inspection. This was my information bureau. I had found the natives trustworthy, and I knew they would not pick up specimens near by and claim they had been brought from a distance. Some that I thus examined had been brought seven hundred miles. 
By a careful examination and classification of these specimens I was able to determine the various geological formations of the district, and the next three weeks were spent in this important work. I wanted to be off again promptly, but as Christmas was at hand, it was impossible to secure dog-teams; so I was obliged to rest.

As I sat in my cabin on Christmas eve, thinking over old times, and feeling, perhaps, a trifle blue, I determined to usher in the great day with some éclat. So I loaded up every firearm that I had, and when midnight came I stepped outside and "let loose" with revolvers, rifles, and shotguns. The first effect was to wake up four hundred dogs, who responded with howls and barks, which they kept up till morning. At seven o'clock, my Russian friends came flocking over to find out what I was celebrating. I told them that it was our Christmas day. Their Christmas comes twelve days later than ours. When they found out the cause of my exhilaration they slipped away, but within three hours the women and children began to appear, each loaded with a steaming dish. There were meats, fowls, berries, pasties, fish, blubber, stuffed ptarmigan, deer tongues, and other things-enough to feed a hundred men. When the table was so full that it could hold no more, they put the dishes on the floor. I knew well that they had brought much 
more than I could handle, and I was somewhat embarrassed by their excessive generosity. But my fears were ill-founded, for soon the whole village began to arrive. The priests and magistrates came first, and then the rest in descending scale, and by the time they were done, all the good things that they had brought had been consumed, as well as all that I could obtain from Mrs. Braggin. Two hundred were fed, and by night I was entirely cleaned out-cupboard, shelf, and cellar. What the small children could not eat they put in their pockets. The Russian storekeepers sent me a bag of coppers, telling me that it was the custom to give each child a coin on such occasions. When I went to bed at night, I determined that $I$ would never again disturb the peace of Christmas night with firearms.

On New Year's eve, fearing that the ceremony might be repeated, I stole away on my snow-shoes and spent the day hunting ptarmigan. I had good luck, and bagged all I could carry. These beautiful little birds are about the size of a pigeon, but of heavier build. In summer their color is brown, but in winter it is pure white, and they sit motionless in the snow, so that it is almost impossible to discover them. The native boys kill them with bows and arrows. Almost all the natives of the far north are good shots, being trained to it from boyhood. In 
order to catch ermine and belk (arctic squirrel) they must be marksmen of the first order; for these animals are small, and must be shot in the head, or the skin is worthless. For this purpose, twenty-two caliber rifles of German manufacture are used. They are muzzle-loaders, and can be purchased in Vladivostok for four roubles. The natives rig them up with a forked rest, and an ermine at seventy-five yards stands no chance of escape.

About twenty years ago the Russian Government sent a company of expert Cossack riflemen into this north country to teach the natives how to shoot. These instructors never got further than Ghijiga, though it had been the plan to distribute them throughout the district. Targets were set up, and the Cossacks did some fancy shooting. The natives looked on stolidly, and when asked to shoot, declined to do so, but called up some of their boys, who easily worsted the Cossacks at their own game.

The natives were always curious about my Colts forty-five caliber six-shooters, as this weapon is not known in that section. In my younger days, I had seen something of Arizona and Texas life, and thought I was a pretty fair shot. One day a native with whom I was stopping asked me to let him have a shot with my revolver. I tore a small piece of paper from my 
note-book and pinned it on a tree about twenty yards distant. I shot first, and came within an inch or so of the paper-a fairly good shot; but the old Korak took the weapon, and, bringing it slowly into position, let drive, and hit the paper. I could detect no look of exultation on his face, nor on that of any spectator. They took it as a matter of course that their tribesman should outshoot me with my own weapon, the very first time he ever had one like it in his hand. I have never tried to shoot against a Korak since then. My only consolation was that it might have been an accident, for he refused to shoot again, although I pressed him to do so. For hunting large game, they use a forty-four caliber Winchester, or a forty-five caliber German muzzleloader.

The feasting at the Russian Christmas-tide lasts fully three days. In the morning the entire population attends church, after which, apparently, a contest ensues as to who shall get drunk first; and the priest generally wins. 'They hitch up their dog-teams, and go from house to house, feasting and drinking. Etiquette demands that a man use his team, even if calling at a house ten rods away. The women troop about in gay. dresses of calico, with bright silk handkerchiefs over their heads, and the men in their best furs, embroidered with silk. One of the most distinc- 
tive features of a Christmas celebration is that each person takes a full bath with soap, before the great day is ushered in. At the same time, the hair is combed and done up afresh. The transformation is so great that it is often hard even for bosom friends to recognize one another. All day long bands of boys go about singing carols. 'They enter one's home, and bow before the icon, and sing their songs, after which it is the proper thing to give each of them a coin or something to eat. In the evening, young men repeat the same performance, except that they bring large illuminated wheels, which they whirl before the icon as they sing the Christmas hymns. They receive about half a rouble apiece for this service.

The next day I started in to return their calls. It is an insult not to taste every dish on the table of your host, and the result was that I soon reached my utmost capacity. In the evening, I dined with Mrs. Braggin, and afterward the room was cleared, and the whole village came in for a dance. For music, we had a piano, an accordion, and a violin; the last was played by an old Russian, who knew sixteen bars of a single tune, and repeated it over and over, ad nauseam. In this primitive fashion, we made merry till the morning. The dance was a curious kind of quadrille, in which the men did almost all the 


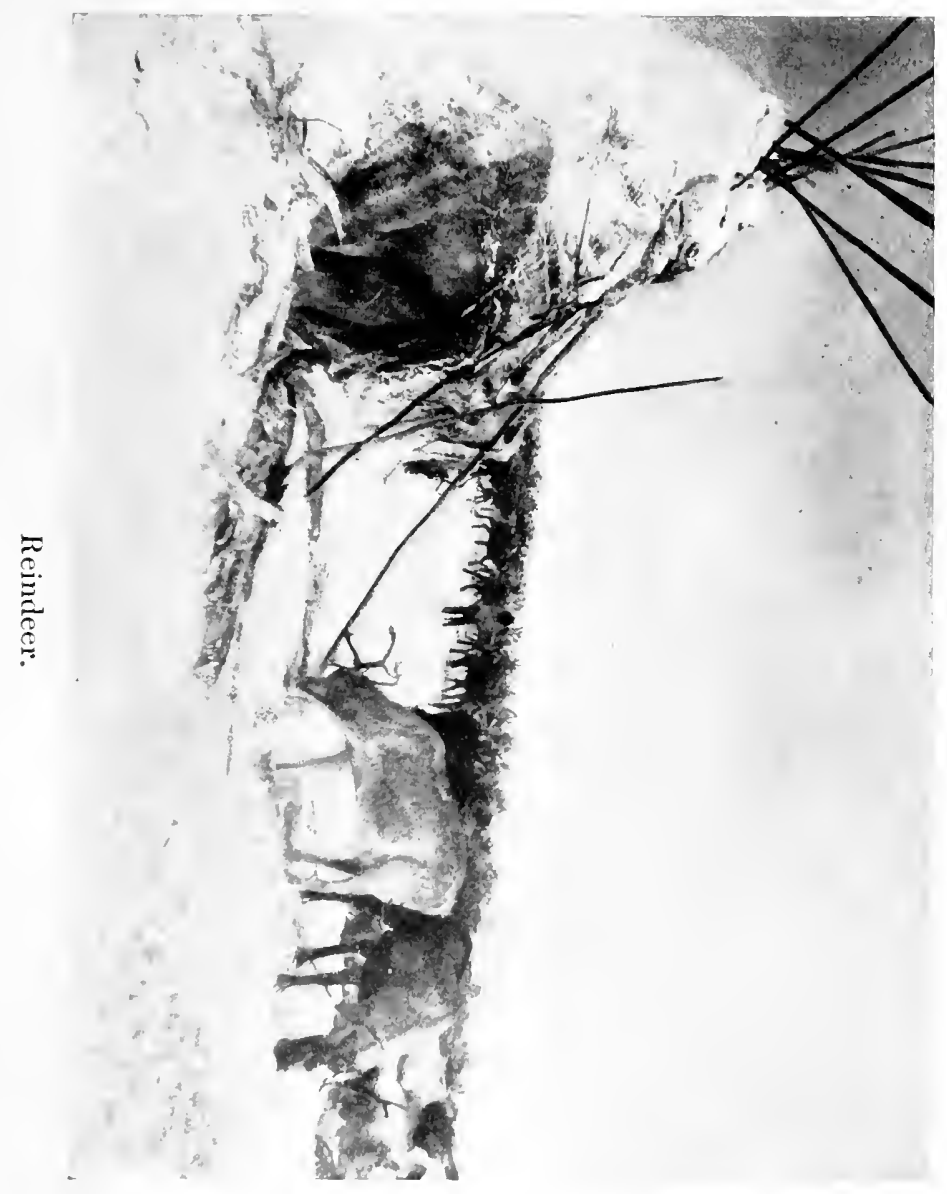



dancing. The ladies stood at the corners, and the men in the center. The men danced very energetically, with many steps that resemble the "bucking" and "winging" of the negro in the United States. At the same time, they shouted at the top of their voices. As for the women, they merely moved forward and back, with little mincing steps, and then turned around in their places. All this time the samovar was going full blast, and every one was streaming with perspiration.

About midnight, the fun grew fast and furious, and every one started in to kiss and hug his neighbor; for by this time, more than half were intoxicated. The worst feature of such a Russian festive occasion is, that every one grows fearfully affectionate as he begins to feel the effect of the liquor.

When the Christmas festivities were over, I made preparations to carry out a more extensive plan of exploration. It was my purpose to examine the valleys of the rivers running from the Stanovoi range of mountains into Bering Sea; the beaches along the shore of that sea, and then to turn south to Baron Koff Bay, on the eastern coast of Kamchatka, where sulphur deposits were said to have been found; then across the neck of the Kamchatka Peninsula to Cape Memaitch, and around the head of the Okhotsk Sea 
to Ghijiga, my starting-point. This trip was in the form of a rough circle, and the total distance, including excursions, proved to be upward of twenty-five hundred miles. This distance I had to cover between January 15 and May 15, when the road would no longer be passable for sledges.

My first work was to select and buy the best sledge-dogs to be found in the town. By this time, I had become fairly adept at driving a dogteam. Old Chrisoffsky did not care to undertake such a long trip, and so I selected as my. head driver a half-caste named Metrofon Snevaydoff. Two villagers also contracted to go as far as the village of Kaminaw, which lies three hundred miles to the northeast of Ghijiga. They would not go further, because the country beyond this was unknown to them. But the magistrate gave me a letter to two Cossacks stationed at Kaminaw, requesting them to furnish native dog-teams to take me on east from that point. I took but little dog-food, as the territory through which I was going abounds in reindeer, and we could get all the meat we needed. Provisions were beginning to run low in Ghijiga, and all I could buy was tea, sugar, tobacco, and a little dried fruit.

It was the middle of January when we started out, all in good health and spirits. The ther- 
mometer stood at forty-six below zero. The dogs were fat, and their feet were in good condition. We whirled out of the village at breakneck speed, followed by friendly cries of "Dai Bog chust leewee budet!" (" God give you good luck!")

I had all I could do to manage my team. The road was worn perfectly smooth, and the sledge would slew about from side to side in constant danger of striking some obstruction and going over. I had to pull off my koklanka and work in my sweater, and yet even in that biting air the exercise kept me quite warm. In two hours the dogs settled down to a steady six-mile gait, and, leaving old Chrisoffsky's house on the left, I laid a direct course over the tundra for the mountains now visible far to the northeast. By five o'clock, we saw signs of deer, which showed us that we were nearing the encampment that was to be our lodging-place for the night. Mounting a rise of land, we beheld, scattered over the face of the landscape, thousands of reindeer which belonged to the denizens of half a dozen skin yourtas, sheltered from the wind in the valley below.

Snevaydoff's team, which was in the lead, caught the scent of the deer, and dashed down the hill, and I after him, though I jammed my polka down and braked with all $\mathrm{my}$ might. It 
had no effect on my speed, and I saw that I was simply being run away with. On the left, near a yourta, a bunch of deer were standing, and, in spite of all my efforts, my dogs left the road and bolted straight for them. The deer bounded away in mad flight. Snevaydoff had already turned his sledge over and brought his team to a halt, but I was enjoying a new sensation. I pulled out my polka and "let her slide," literally. I was minded to save the Koraks the trouble of slaughtering a few of their deer by doing it myself. Just as " Old Red" got a good mouthful of hair, our flight suddenly came to an end with the sledge turning upside down. The natives hurried up and caught the dogs, and, bringing them down to the yourtas, fastened them securely.

I have coursed antelope in Texas, and in Arizona have picked wild turkeys from the ground while on horseback, but for good exhilarating sport give me fourteen wild sledge-dogs, the open tundra, and a bunch of deer ahead.

I found, to my surprise and pleasure, that the old Korak in charge of the village was the one who had helped me the summer before when I was trying to find my way back to Ghijiga. I was now better able to talk with him than I had been at that time, especially as I had Snevaydoff. for interpreter. After tea, I went outside to see 


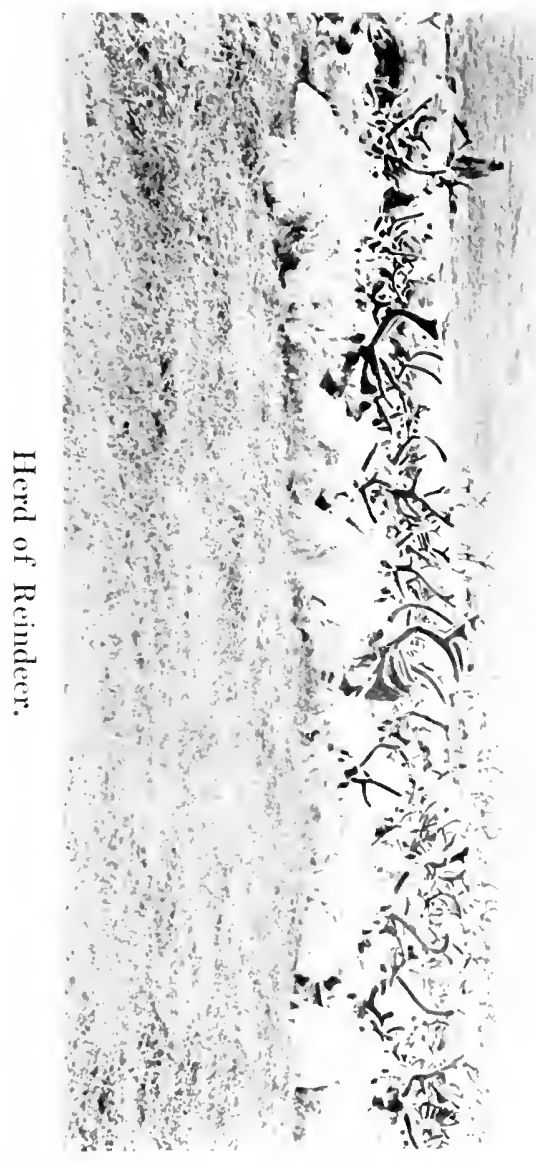



how things were getting on. Four men were out among the herd, lassoing those intended for slaughter. 'They did it much after the fashion of cow-boys at home. Having secured an animal, two men held it while a third drew out a long, keen knife and plunged it into the animal's heart. The poor beast would give one or two wild leaps, and then fall dead. The Koraks do not bleed their animals when they butcher them. This scene was enacted three times, each deer being intended as food for a single tcam of dogs. It took place in plain sight of the dogs, who leaped in their collars, and yelled applause at every stroke of the knife.

The men's work ended with killing the deer, and the women and children followed, the former with sharp knives, and the latter with bowls. It was their part of the work to skin and cut up the dead decr. With a deft stroke, they ripped up the belly and drew out the entrails, being very careful to leave all the coagulated blood in the abdominal cavity. When the viscera had all been removed, the carcass was tipped up, and the blood was caught in the bowls, and carried to the dogs. The tongue and the leg-bones were removed and laid aside for home use, and all the rest of the carcass went to the dogs.

As the women were skinning the deer, I noticed that every few moments they would lean 
down and tear off, with their teeth, little round protuberances which grew on the under side of the skin. These were an inch long by a quarter of an inch thick, and were bedded in the skin, and surrounded with fat. They proved to be bots, formed by a fly that is the special torment of the deer in summer. On one skin I counted more than four hundred of them. A little child came up and offered me a handful. I found that they are considered a delicacy by the natives. The flies deposit minute eggs in the skin in midsummer, and the larva lies under the skin, imbedded in fat. The following spring the deer is tormented with itching, and rubs against anything it can find, and so liberates the larva, which comes forth in the shape of a fly, an inch in length, only to repeat the same operation. It is a marvelous provision of nature that teaches the fly to seek the only place where its larvæ can be kept warm and safe during the terrible cold of winter.

When the last deer had been skinned, the men brought axes and chopped the carcasses into equal portions, each dog receiving a good ten pounds. When I went back to the yourta I left them snarling and growling over their meal, like so many wolves.

The yourtas of these natives are covered with deerhides. The hair is cut down to a quarter of 
an inch in length, and is put on the outside. The construction of the frame-work of the yourta is very ingenious, and is the result of centuries of experimenting. 'They require no guy-ropes to keep them erect, but the frame-work of poles is so constructed and so braced on the inside that they resist the most violent wind. After the poles are lashed in place by the women the deerhides are fastened over them separately, not sewed together; for this would make it difficult to move readily. At the top there is, of course, the usual exit for the smoke.

The yourta that I entered was about thirtyfive feet in diameter and fourteen feet high, and divided, by means of skin curtains, into eight little booths or apartments, each of which could be entirely closed, to secure privacy. These little booths are arranged around the side of the yourta, and each one is occupied by an entire family. The booths are eight feet long, five feet high, and six feet wide, and are heated only by lamps. 'The great fire in the center of the yourta is not primarily for heat, but for cooking purposes, all the families using it in common. The various kettles are hung over the fire by means of wooden hooks. The food is either boiled or eaten raw. They do not seem to know the use of the frying-pan.

The main door of the yourta is formed by 
two flaps of deer skin, an inner and an outer one, which gives the effect of a storm-door. The dogs generally huddle between the two, and occasionally one of them sneaks into the yourta itself, only to be promptly kicked out.

Our dinner consisted of boiled deer ribs, sticks of frozen marrow, and half-digested moss, taken from the stomach of the deer. This last was cooked in seal oil, and looked much like spinach. I found some difficulty in bringing myself to eat it, but I craved vegetable food so keenly that at last I was able to overcome my repulsion, and found it not so bad after all. The reindeer, therefore, furnishes the Korak with meat, clothing, shelter, and vegetable food. The dinner was served on wooden plates, and conveyed to the mouth with fingers, except that for the "spinach" they had spoons carved from the horn of the mountain-sheep. The host persisted in offering me the daintiest lumps of fat in his fingers; and I accepted them. In that far northern latitude, we all craved fat or any kind of oil. The women did not eat with us. The host and I sat in one of the little booths, while the women remained outside by the fire. The children, however, could not resist the temptation to "peek," and they lay on the ground, looking up from below the edge of the skin partitions, like a row of 


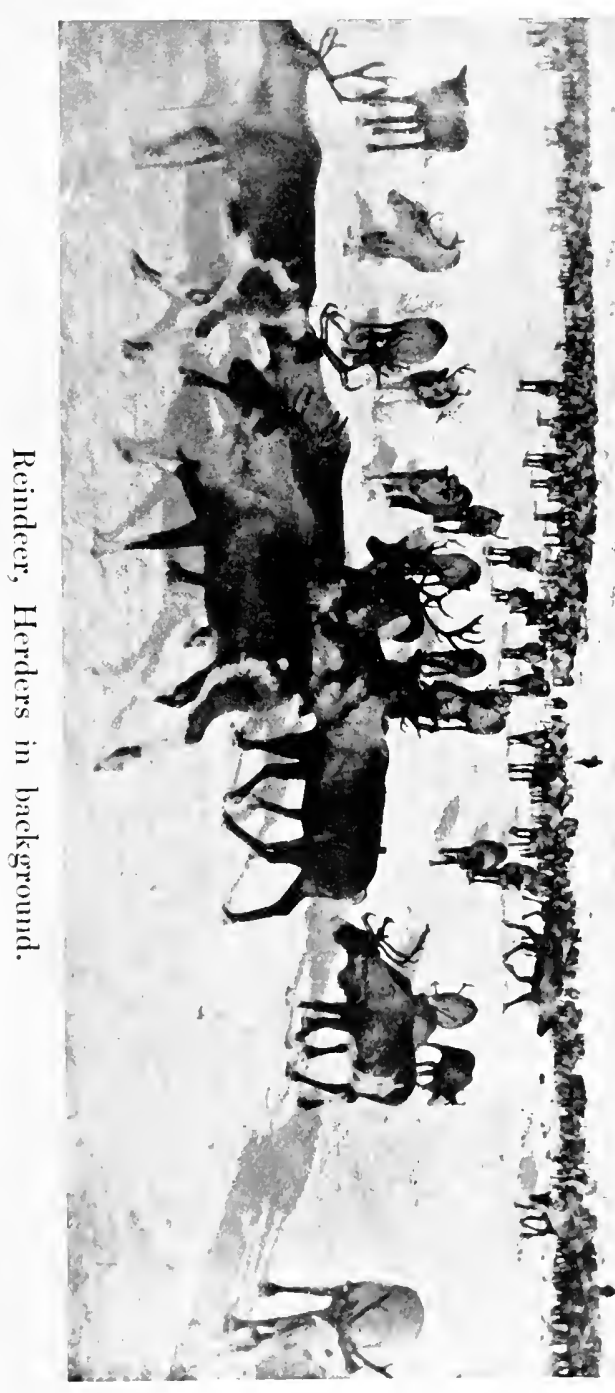



detached heads, with the eyes blinking solemnly at me.

After we had eaten, I made them all happy by sending Snevaydoff out to the sledge for some tea, and some broken bits of sugar. The host brought out the family treasures, the gaudy cups which I have heretofore mentioned. The women licked the saucers, and wiped them with moss, after which tea was served.

Strange is the effect of environment; a year previous, no inducement could have made me use those cups after seeing them cleansed in that fashion. Was I, after all, a savage, and civilization but a thin veneer? I found myself at times looking at life from the standpoint of these people. I was thinking, dreaming, and talking in my sleep in my polyglot language. At times I would talk to myself in English, just to enjoy the sound of it. I had with me no books, except a Bible, which was in my valise, but the print was too fine to read, except with a good light. Action was my only salvation. Had I been compelled to stay in one place I should have feared for my reason.

After two or three cups, every one perspired freely, and off came one garment after another, until the men were entirely naked, and the women were naked to the waist. When we had imbibed ten or a dozen cups, the kettle was replen- 
ished with hot water, and handed out to those in the main part of the yourta. I gave each one a lump of sugar to make him happy, and then, leaning back among the skins, lighted my pipe, and had a long talk with my host, during the course of which I elicited much curious information.

At bedtime, two of the smaller children were put in tiny cradles, swung from the top of the yourta. The compartment in which I slept held eight people that night. The lamp was left burning all night, for the sake of its warmth. As far as I could discover, there was an utter lack of ventilation.

When I crawled out of that noisome hole the next morning, I found that the dogs were very uneasy; they scratched the snow continually with their hind feet. This was a sure sign that one of the dreaded storms-a porgo-was coming. As I had experienced one of them, I had no wish to be caught out in another, so I determined to wait where I was till it blew over. By ten o'clock it was raging, and for three mortal days there was no stirring from that village. Just before the storm came on I secured some photographs of the reindeer. They were very tame indeed, and would come up to me and smell of my garments, and would even lick them, hoping to get some salt. I had to carry a short stick to 
keep them from pressing too close upon me. I walked in among the herd, which numbered about ten thousand, and watched them eat. They would paw away the snow until they reached the moss, which lay about ten inches below the surface, and then, kneeling down, would dig it out with their teeth. The moss is about ten inches thick, and is a loose, spongy mass of vegetation. It will not bear the weight of a man, the foot sinking through it. It forms a most excellent food for deer, but horses will not eat it. The Tunguse deer, which is larger than the Korak, eats only moss, but the Korak deer will eat either moss or grass.

These nomads have regular roads to and from the coast, and generation after generation they follow the same old beaten tracks. In December, they are farthest from the sea. Once in two, three, or four weeks, according to the supply of moss and the size of the herd, they break camp and move off on the trail. Late in December they turn, and gradually work their way back, so that by the time that $J$ une and the mosquitos have arrived they are near the sea. The deer eagerly lick the salt from the rocks, and even drink the sea water. 'They stay on the coast until late in August, when the frosts kill off the mosquitos, and then they move off inland for another winter. In summer, the deer grow very. 
poor and weak, for they find little moss near the coast. All along the shores of Bering Sea thousands of deer can be counted every summer. A few years ago, when the United States Government wished to secure some reindeer herds for Alaska, they sent all the way to Lapland, and imported the deer at enormous expense, took them across the American continent by rail, and shipped them by steamer to Alaska. By the time they arrived, those that had not died must have cost an enormous sum. If the government had sent a steamer a single day's run across Bering Sea, it could have purchased fifty thousand reindeer right on the coast at a cost of one rouble, or fifty cents, apiece. Coin cannot be used in purchasing these animals, for the natives do not understand nor use our coinage, but they can be obtained by barter at the rate of one rouble's worth of tobacco a head. Some rich natives might accept a few silver coins to hammer up into buttons for their children's clothes, but not as a medium of exchange.

The rutting season is in July, and fights between the male deer are not uncommon. But most of the male deer are gelded, only enough being left for breeding purposes. The natives watch their herds carefully, both night and day, but without the use of dogs. The principal enemy of the deer is the great gray Siberian 


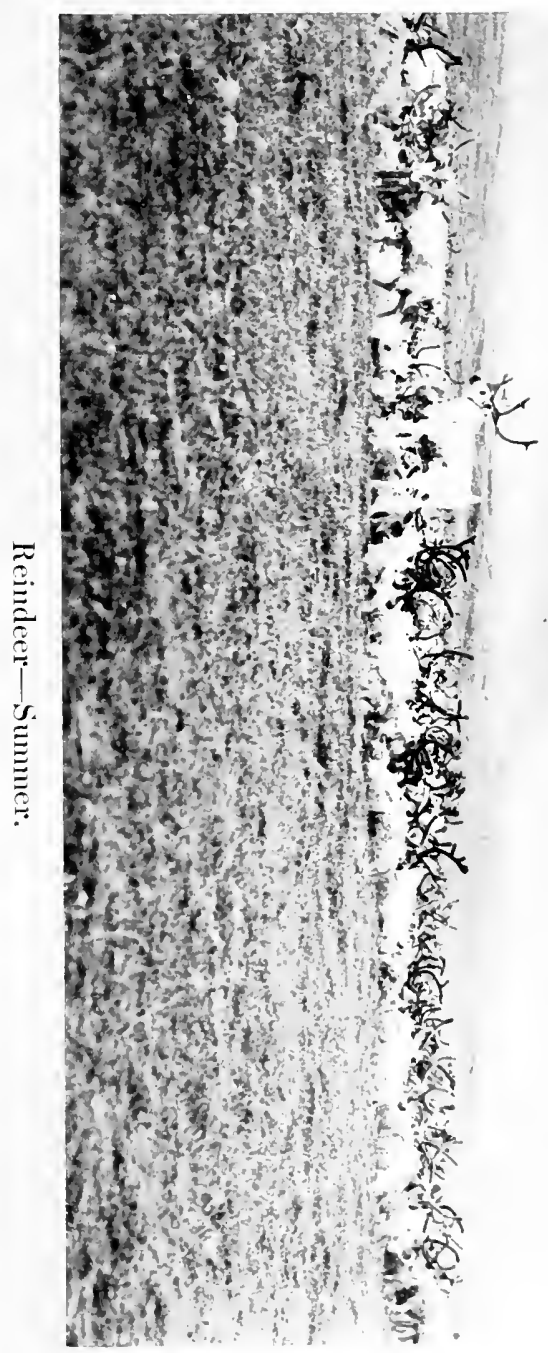



wolf, which stands as high as a Saint Bernard dog. One of these wily. fellows will dash into a herd, "cut out" three or four deer, and run them off into the wilderness. When a deer grows tired the wolf runs alongside, and, seizing it by the nose, brings it to the ground and despatches it.

The Koraks eat the hoofs after burning them on the fire and thus setting free the gelatin. The weapons used by the Koraks, and the 'Tunguses as well, are the modern rifles, or in default of these the regular old-fashioned muzzle-loader. They do a little trapping, but only for sport. The little boys take out the knuckle-bones from wolves' feet and set them up like ninepins, and pitch stones at them. Even the grown men sometimes indulge in this sport. It is not their custom to use the reindeer under the saddle. They do not even carry a pack, as among the Tunguses. Even in summer the Korak prefers to carry his goods on a sledge, as many as eight deer sometimes being required to draw the load.

There is one physical feature which helps to determine the geographical division between the " dog" people and the "deer" people; and this is the depth of the snowfall. For instance, on the peninsula of Kamchatka there are many places where the snow is so deep that the deer 


\section{SIBERIAN KLONDIKE}

could not dig down to the moss in winter. All through the northwestern portion of the peninsula, however, where the land is occupied mostly by Koraks, the snow is not so deep, and the keeping of deer is possible. 


\section{CHAPTER XIII}

HABITS AND CUSTOMS OF THE KORAKS

The hour-glass houses-Their curious construction-The natives prove to be both hospitable and filthy-Dialects of Dog Koraks and Deer Koraks-Some unpleasant habits-How they reckon time-Making liquor out of mushrooms-Curious marriage customs-Clothes of the natives-Queer notions of a deity-Jealousy of the wandering Koraks-Thieving a virtue and childbirth a social function.

WHEN the storm was over, we harnessed the dogs and continued our journey. Seven days of ideal sledging brought us to Kaminaw, a Korak village at the extreme northern point of the northeastern arm of the Okhotsk Sea, where I was to discharge my Russian dog-teams, and secure others from the natives. My first view of the village was from the summit of a hill half a mile away. I saw what resembled fifty huge hour-glasses set on the plain, which, on a nearer approach, turned out to be ten or twelve feet high. As we drew near, the village came swarming out with a pack of mongrel curs at their heels; and over the edge of eachi hour-glass house ap- 
peared the heads of the women and children, all eager to get a glimpse of such a novel sight as a foreign face. Over each house was suspended a frozen dog. These were impaled under the chin on the sharp end of a pole, and lifted high in the air. I learned later that this was a form of sacrifice to the Fish God, and was intended to insure a good run of fish the next season.

As I tumbled out of my sledge, I was surrounded by the filthiest lot of natives $I$ had yet seen. Their furs were old and mangy, and the hair was worn off in spots. The people were kind and pleasant, and seemed bent on shaking hands with me. I was pressed on all sides with invitations to enter one and another of the curious houses. As I stood there, debating what I should do, the chief of the village elbowed his way through the crowd, took me by the hand, and led me to the largest of the liuts. In order to enter we had to go up a ladder to the height of ten feet or more. This ladder was a log of driftwood, split down the center, and provided with little holes in which to put the toes in ascending. These natives have very small feet, and I found the holes in the ladder too small to insert my toes, but I managed to scramble to the top. I was now standing on the edge of an inverted octagonal cone, made of logs lashed together, the inside or crater of the affair, which 


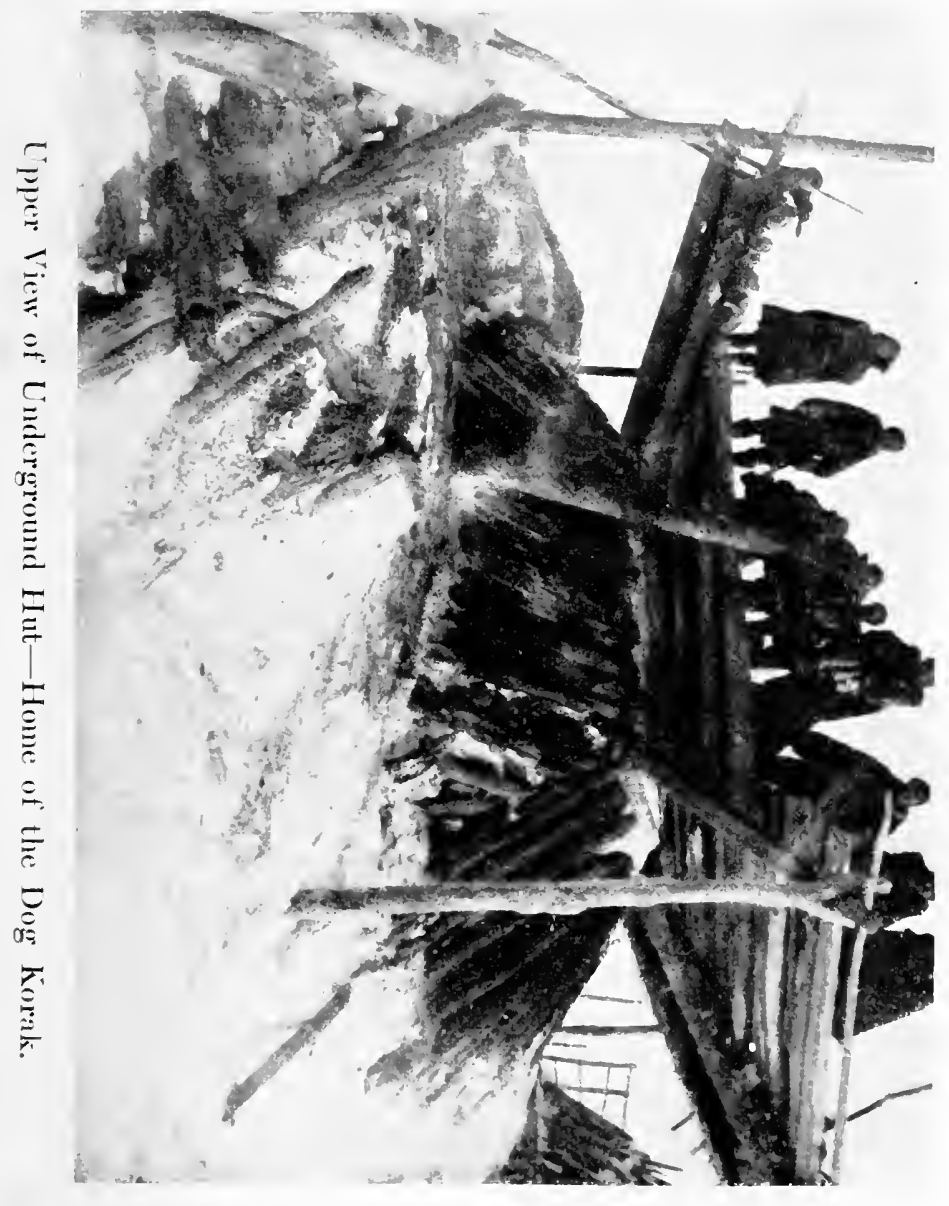


was eighteen feet across, sloping down at an angle of about fifteen degrees to the center. At that point there was a hole leading down to the interior of the house. 'The hole also sufficed for a chimney, and to enter the house one had to go down a ladder through the smoke. Santa Claus is said to come from the north, and it is evidently among this people that he originated, for here everybody enters his house by way. of the chimney.

This flaring line of logs protects the opening of the house from being covered up with drifting snow. This is the main reason for building in this fashion. Moreover, the high scaffolding thus provided is an excellent storehouse, upon which all sorts of things can be placed without fear of molestation from wild animals. I saw here a miscellaneous collection of implements, dog-harness, oars, fishing-tackle, and firewood. I followed the chief down the ladder through the smoke. The hole was two feet wide and three feet long. I found myself in a semi-subterranean apartment, thirty feet in diameter and fifteen feet high. As we stood on the floor, our heads were about level with the general surface of the ground. 'The frame was strongly built of timbers, evidently driftwood; but everything was black with age and smoke. I found it so warm that $I$ had to remove my furs. 'The room 
was very dimly illuminated with what little light filtered through the hole in the roof; and even this was partially obscured by the smoke that was always passing up and out.

As soon as my eyes became accustomed to the perpetual twilight of the place, I perceived that around the apartment ran a raised wooden platform, one foot high and six broad, on which lay. piles of deerskins. The women were busy clearing off a place for me, shaking out the skins and choosing the best ones for my accommodation. With native courtesy, which had no stiffness about it, the old gentleman led me to my place, sat down beside me, and began to talk. I pointed to my ears to show that I did not understand him.

There seemed to be little difference between the dress of the men and the women, excepting that the wide "bloomers" of the women were made of alternate strips of black and white deerskin. Their clothes were indescribably old and shabby and dirty, and their faces were anything but clean; but for all that, there were some very comely people among them. The women wore their hair in two braids, wound about the head, and fastened at the top in front.

In these rooms one would naturally expect the worst in the matter of ventilation, and I was surprised to find that it was exceptionally good. 
They are enabled to arrange an air-shaft so that it enters the room, near the floor, on one side. The draft, made by the heat of the fire rising through the smoke-hole, causes pure air to be drawn through this ventilating shaft. In fact, there seemed to be no reason why these dwellings should not be made perfectly comfortable and sanitary.

The women appeared to be very busy, and even the children were industriously making thread from the sinews that lie near the backbone of the deer.

In this house I found an explosive harpoon that the natives had taken from the body of a whale. It had been fired from the deck of some whaling-vessel, and had been deeply embedded in the flesh of the animal. It bore no name.

The Koraks have two dialects, one of which is spoken by the Dog Koraks, and the other spoken by the Deer Koraks, but the slight variations are not marked enough to constitute a serious barrier to communication between them. All these tribes, without doubt, belong to the great Turanian family, and are allied to the Mongols, Ostiaks, Samoyeds, and other tribes of northern Asia. The evidence for this is both physiological and philological.

The writer before quoted says truly of these people that " their manner of living is slovenly, 
to the last degree; they never wash their hands or face, nor cut their nails; everything about them smells of fish; they never comb their heads, but both men and women plait their hair in two braids; when any hair starts out they sew it in with threads to make it lie close; and, as a result, they have such a quantity of lice that they can scrape them off by handfuls." 'Time seems not to have weaned them from these disgusting habits.

These people reckon ten months to the year, not by reference to the changes of the moon, but by the order of special occurrences which take place each year, with sufficient regularity for the purpose. 'The months in their order are: Purifier of Sins, Breaker of Hatchets, Beginning of Heat, 'Time of the Long Day, Preparing Month, Red-Fish Month, White-Fish Month, Kaiko Fish Month, Great White-Fish Month, and Leaf-Falling Month. Others name them as follows: River-Freezing Month, Hunting Month, Purifier of Sins, Breaker of Hatchets, Long Day Month, Sea Beavers' Puppying Month, Sea Calves' Puppying Month, Tame Deer Foaling Month, Wild Deer Foaling Month, Beginning of Fishing.

A peculiar custom sometimes to be noted among these people is that of drinking a kind of liquor made from a large species of mushroom. The effect is, in some respects, similar 


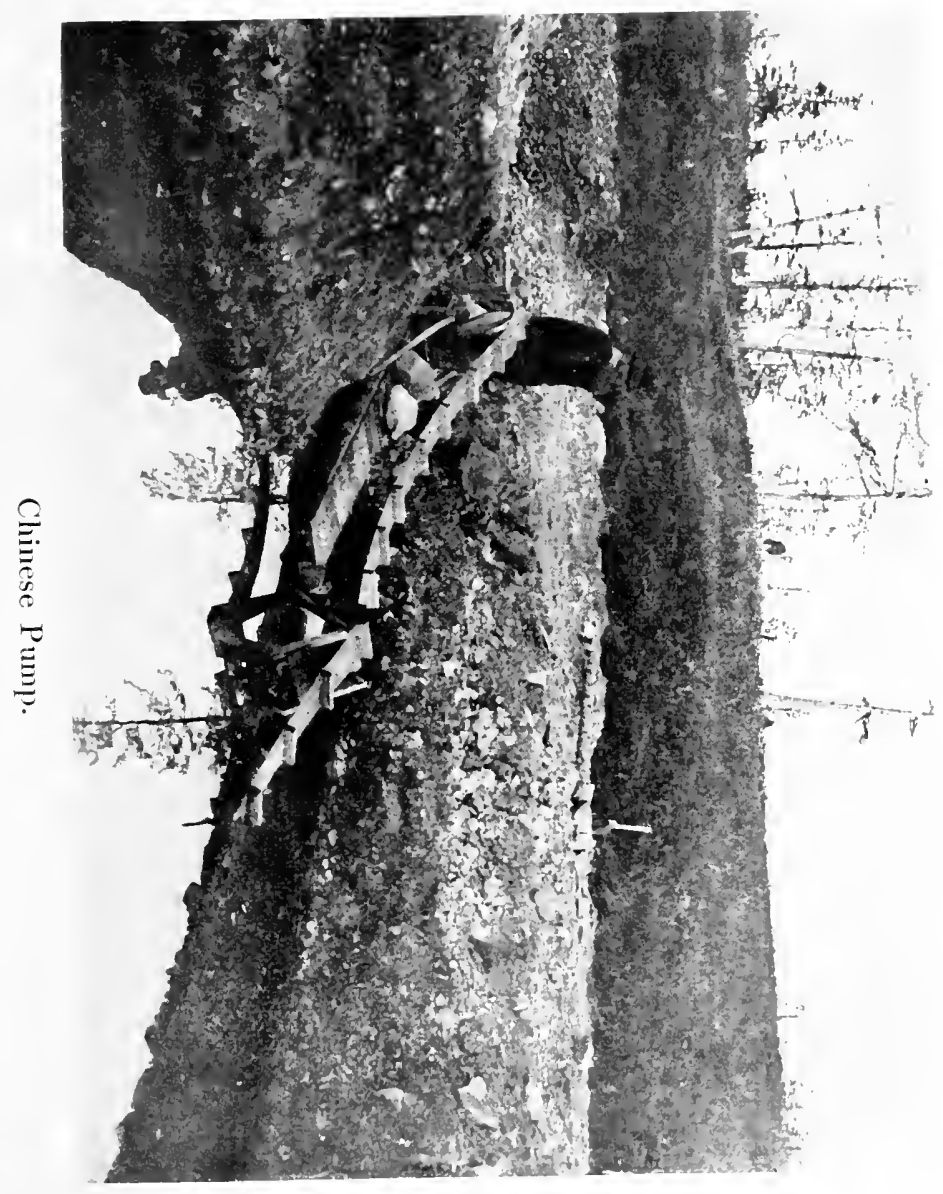


to that produced by the use of hashish. At first the imbiber shakes as with the ague; and presently he begins to rave as if in delirium. Some jump and dance and sing, while others cry out as if in agony. A small hole looks to them like a bottomless pit, and a pool of water as broad as the sea. These effects are produced only when the beverage is used to excess; a small quantity has much the same effect as a moderate amount of alcoholic liquor. Curiously enough, after recovering from one of these debauches, they claim that all the antics performed were by command of the mushroom. The use of it is not unattended with danger, for unless a man is well looked after he is likely to destroy himself. 'The Koraks sometimes take this drug in order to work themselves up to the point of murdering an enemy. Three or four of the mushrooms is a moderate dose, but when one wants to get the full effect one takes ten or twelve.

When a native resolves to marry he looks out for a bride, not in his own village, but in a neighboring one. When he finds a girl who pleases him, he tells her parents that he is desirous of serving them, and, during this period of probation, he works most industriously in order to make a good impression. At last he asks permission to steal the girl. If his suit is looked upon with disfavor, he is paid for the service he 
has rendered and sent away, but if he is acceptable to the girl and to her parents and relatives, the permission is given. He then seeks an opportunity of finding the girl alone, which is no easy matter, for she is supposed to be guarded by the women of the village. Besides, the girl is covered with two or three coats, and is wrapped about with fish-nets and straps, so that motion is almost impossible. If the young man succeeds in finding her alone, or in company with only one or two women, he seizes her and begins tearing off her garments, for this constitutes the ceremony of marriage. But this is not an easy thing to do; for, though the girl herself makes little resistance, such other women as are about fall upon the would-be groom without mercy, and beat and scratch him and use every means to prevent him from accomplishing his purpose. If, however, he is successful in tearing off her garments, he immediately walks away from her, whereupon she gently calls him back, and the ceremony is complete. It seldom happens that the young man succeeds the first time, and instances are known where a man has tried for several years to secure his bride, without success.

When successful, the groom carries off his bride to his own village without any ceremony; but after some time they return to the bride's home, and a marriage-feast is celebrated, some- 
what after the following manner: the bridal party, including the bridegroom's friends, approach to within a hundred paces of the village from which the bride has been taken. They sing and go through certain mystic rites with a fish's head wrapped in tow and carried by an old woman. A coat of sheepskin is put on the bride, and several images are hung about her till she can hardly bear up under the load. A boy of the village comes out and leads the bride in by the hand. When she comes to the hut of her parents, a strap is tied around her, and by this she is let down into the underground house. The fishhead is laid on the floor at the foot of the ladder, and the bride and all who follow step on it, after which it is thrown into the fire. 'The bride is stripped of all her superfluous ornaments, and the company take their places about the room. The bridegroom builds a fire and prepares the food, which had been brought for the purpose, and entertains the people of the village. The next day, the host entertains the visiting company, after which every one goes home, except the bride and groom, who remain to serve her father for a time.

The dress of the men differs but slightly from that of the women. Both wear the same kind of upper garment, with the skirts either cut off an equal length all around, or with the back part 
longer than the front. The women have an under garment which they usually wear at home. It consists of a combination of trousers and waistcoat, the trousers being tied about the leg below the knee, and the waistcoat being tied with a cord. As might be supposed, the covering for feet and ankles is a most important matter in this far northern country. In the summertime, when the ground is generally one wide marsh, they wear the skins of seals, with the hair turned out, but often make their leggings of the skin of reindeer legs. The very finest foot-wear is made with the sole of white sealskin, and the upper of fine dyed leather from the hind quarters of a white dogskin. The part that incases the calf of the leg is made of dressed leather or dyed sealskin. The tops are always richly embroidered with silk thread. If a young man is adorned with these shoes, immediately it is coneluded that he is in search of a wife.

Since the complete conquest of these parts by the Russians war has been practically unknown, but during the process of conquest the natives made a stubborn resistance. They never fought in the open, but always by stratagem. A company of Cossacks, arriving at a village, would be hospitably received, the tribute would be paid, and large presents made in addition; but when all suspicion had been lulled to rest the Cossacks 
were likely to wake in the night to find themselves in the midst of flames. If any one succeeded in breaking through the flames, a worse fate awaited him; for then he was slowly tortured to death by burning, or cut to pieces and disemboweled while yet alive. If the natives were in strong force, upon hearing of the approach of the Cossacks they would retire to some high place, which they would strongly fortify and hold as best they could against the invaders. If unable to hold their position, they would first cut the throats of the women and children, and then throw themselves over a precipice, or rush upon the enemy to be ruthlessly cut down.

These people have indistinct notions about a deity, but they render him no homage. On the contrary, they treat his name with the utmost irreverence, and relate stories about him that rival the scandals of Olympus. They blame him for making so many steep hills, so many rapid rivers, and for sending so many storms. Sometimes they raise a pillar in the plain and bind it around with rags, and whenever they pass, throw at it pieces of fish or other food. But it is noted that they give nothing that they can use themselves-only the tails of fish or other refuse. Besides these pillars, there are other places that they reckon sacred, such as smoking mountains, hot springs, and certain forests, all of which they 
imagine to be inhabited by devils, whom they fear much more than the gods.

A Russian who lived for a long time among these people says of them:

All their beliefs concerning both gods and devils are certainly very simple and ridiculous; however, it shows that they endeavor to account for the existence of everything as far as they are able; and some of them try to penetrate into the thoughts even of the birds and fishes. But when once a belief is established they never trouble themselves with inquiring whether the thing be possible or not. Hence their religion depends entirely upon ancient tradition, which they believe without questioning. They have no notion of a supreme being that influences their happiness or misery, but hold that every man's good or bad fortune depends upon himself. The world, they believe, is eternal, the soul immortal, and that it shall again be joined to the body and live eternally, subject to the same fatigues and troubles as in this present life, with this difference only: that they shall have a greater abundance of all the necessaries of life. Even the smallest animals, they believe, will rise again and dwell under the earth. They think the earth is flat, and that under it there is a firmament like ours; and under that firmament another earth like ours; in which when we have summer they have winter, and when we have winter they have summer. With regard to future rewards and punishments they believe that in the other world the rich will be poor and the poor will be rich.

Their notions of vice and virtue are as extraordinary 
as those they entertain of God. They believe everything lawful that procures them the satisfaction of their wishes and passions, and think that only is sinful from which they apprehend danger or ruin; so that they reckon neither murder, suicide, or adultery, oppression, nor the like any wickedness: on the contrary, they look upon it as a mortal sin to save any one that is drowning, because, according to their notions, whoever saves such an one will soon be drowned himself. They reckon it likewise a sin to bathe in or to drink hot water, or to go up to the burning mountains.

They worship several animals from which they apprehend danger. They offer fire at the holes of sables and foxes; when fishing they entreat the whales or seahorses not to overturn their boats; and in hunting they beseech the bears and wolves not to hurt them.

The wandering Koraks are extremely jealous, and sometimes kill their wives upon the merest suspicion. Adultery is punished by the death of both parties. This extreme jealousy on the part of husbands accounts for the fact that the women take no care of their persons, and are always dirty and repulsive. They say that their husbands believe that any attempt at personal adornment would be a sign that they were wavering in their affections, for their husbands can love them without any such adornment. With the Koraks who live in the "hour-glass" houses the case is reversed, for they are extremely care- 
less of the virtue of their wives and daughters; so much so, that frequently they lend either the one or the other to their guests or special friends. A refusal of this civility they consider the greatest affront.

Among all these tribes, except the Kamchadales, theft is considered reputable so long as one does not steal from people of his own tribe. When discovered, theft is punished severely, but only because the thief was not clever enough to escape detection. A Tchuktche girl may not marry until she has proved her dexterity in this line. Murder is not looked upon as particularly heinous, unless one kills a fellow-tribesman. In that case the relatives of the dead avenge the crime. Consanguineous marriages are extremely common. A man often takes a cousin, an aunt, or even a mother-in-law as his wife. In fact, any relative except his mother or daughter may become his wife.

As soon as a child is born they set aside for it a number of reindeer, but the child cannot claim them till he has reached maturity. In naming a child, they often go through a certain formality. Having set up two sticks, they tie a string across the top, and from the middle hang a stone. Then they repeat the names of the child's relatives, and, during the course of this recital, should the stone appear to shake or move, the 
name spoken at that moment is given to the child. Without doubt the most curious custom among these people is that childbirth is a public function, and the whole village may assemble to witness the event.

The dead are commonly burned. The corpse is dressed in his finest clothes, and drawn to the place of cremation by his favorite deer. A great pile of wood is fired, and into the flames are thrown the dead man's arms and some of his household utensils. After this the deer are killed, and they, together with the man's body, are thrown upon the fire. A year later they bring to the place of cremation two young deer and a large number of deer horns, and, burying the latter, they make a pretense of sending a herd of deer to the dead man for his use in the nether world. 


\section{CHAPTER XIV}

OFF FOR BERING SEA-THE TCHUKTCHES

The Tchuktches are the Apaches of Siberia-Their hospitality to Americans and their hostility to RussiansWherein my experiences differ from those of Mr. Harry DeWindt-Result of licking a piece of stone with the thermometer at $45^{\circ}$ below zero-Konikly-Power of moral suasion in dealing with a rebellious Korak-The cure of a dying woman and the disgust of her husbandPoll-tax and the Tchuktches.

TMMEDIATELY upon our arrival at the I village of Kaminaw I began looking about for dog-teams to take me on the long trip around by the shore of Bering Sea. I found it very difficult to get good dogs there, but after four days of patient search I secured two strong young natives, each with a team of twelve dogs. I contracted with them to accompany me all the way from that point, a distance of over fifteen hundred miles, for fifty pounds of tobacco and twenty pounds of sugar, all of which I paid in advance.

Thus equipped I left Kaminaw, and pushed 
toward the northeast, following the line of mountains, and examining the rivers and creeks, the cañons and the gulches for the precious metal. We generally found Korak villages in which to lodge, but we suffered greatly with the excessive cold. Not infrequently we had to go without any fire at all, and at such times we found raw meat preferable to empty stomachs.

The next few weeks we worked our way toward the coast, one day succeeding another in the monotonous iteration of camping and breaking camp, and digging down into bed-rock in a fruitless search for paying gold. As we approached the coast for the first time, we fell in with members of the Tchuktche tribe. This name is generally spelled Tchou-tchour, but I found the name invariably pronounced T'chuktche, the apostrophe signifying that the initial $T$ is pronounced separately. These people are generally supposed to be a rather ugly lot, and the Russians have never been able to subdue them as they have the other Siberian tribes. They are the Apaches of Siberia, and when attacked they retire to their mountain fastnesses, where it is next to impossible to reach them. They are purely nomadic, and subsist solely upon their immense herds of reindeer. They are much taller and broader in the shoulder than is characteristic of any of the other tribes 
that I have seen. Many of them stand five feet and eleven inches. The women, too, are tall and well-formed.

I had been warned by the Russian authorities at Ghijiga to be on my guard when I fell in with these fierce people, but I found the warning entirely unnecessary. They had a clear knowledge of the difference between a Russian and an American. Their preference for the American lies in the fact that the Russians have tried to make them pay tribute, and have carried on a desultory war with them for fifty years, while the American whalers bring them articles of trade of which they stand in need. They took the greatest interest in me, and did everything in their power to make me comfortable. In their sledges they would take me on long drives up the water-courses to look for gold, and in countless other ways showed their good will. They were the only people in Siberia with whom we could not bargain for meat or transport. They simply would not listen to my offers of pay, and it was only with difficulty that I could get them to take presents of tobacco or tea. They smilingly told me that I had better keep all those things till I went south into Kamchatka, " where all the people are thieves." I felt so safe among the Tchuktches that never once did I take my guns from the pack and bring them into the tent 


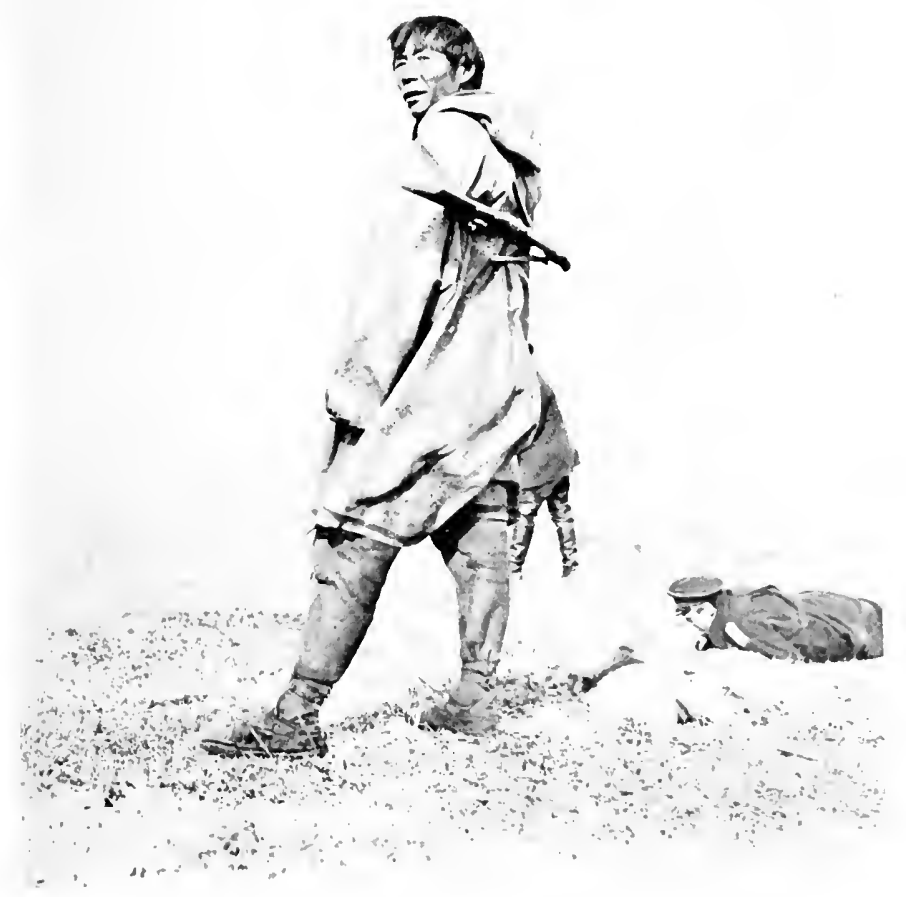

One of the Tohuktches-an unconquered Race. 

with me. One instance will illustrate the manner in which these good people treated me. At one point I had to take a three-days' trip over the mountains. It required twenty-five reindeer and five drivers. The village chief insisted on carrying my baggage, leaving my dog-teams to come on behind, unloaded. For this service I succeeded in making him take twenty cartridges.

Mr. Harry DeWindt crossed over from the American side, and reported later that he had been captured by the natives, and, after undergoing great hardships, was rescued by a man-ofwar. In view of my experiences among this people it is very difficult to understand the treatment that Mr. DeWindt received. I traveled all along the coast to the same places visited by him, and was always treated as an honored guest by the natives. On the whole, they are the finest race of savages that it has ever been my lot to meet.

The trip had been barren of results, as far as gold was concerned. Not long after leaving Kaminaw I struck a sandstone formation, and lost all traces of the yellow metal. And now I was approaching the coast, though I had not as yet caught sight of it. On the eighth of March we reached the foot of a range, and one of the Koraks, pointing to a distant summit, said that from that point we would be able to sce the 
ocean. With renewed courage we pushed on. Each of the dogs wore on his feet soft deerskin moccasins, and the teams were being very carefully handled, for they were sadly worn by the long journey. They now needed constant urging. We no longer rode on the sledges, but walked beside them, pulling on the bow to relieve the dogs. When the hills were too steep, we had to double up the teams and make two trips, which lengthened the journey materially. During this period I was compelled to keep my beard trimmed close to my face, because I found, by hard experience, that my mustache would freeze down to my beard in such fashion that I had a mass of ice depending from my face, which had frequently to be cut away with a knife. In ordinary cold weather a beard is a protection from the cold, but under those circumstances I found that it added greatly to my discomfort.

Natives will pay more for short-haired dogs, for, in the case of the long-haired dog, the moist breath, as it flows back from his nostrils, soon covers him with a mass of icicles. With the short-haired dog this is impossible.

One day, shortly before we reached the coast, we camped at noon, and, about half a mile away, I saw a peculiar outcrop of white rock. Thinking that it might be worth prospecting, I put on my snow-shoes and walked over to it, while the 
men were getting dinner ready. The thermometer stood at forty-five below zero. I found that there was only a soda-like incrustation on the rock. And then, without thinking of the after effects, I took up a piece, about two pounds in weight, and put it to my mouth to taste it. Of course my tongue stuck to it, and an excruciating pain shot through that organ. I had taken a generous lick, and the whole surface of my tongue was fastened firmly to the stone. I managed to get back to the camp, still holding the stone to my face. For a moment, the men gazed at me in wonder; then one of them hurried to bring a kettle of warm water, which he attempted to dash in my face, but it did not reach the right spot. For what he next did I shall be grateful always. He took a large mouthful of the warm water, and then, with careful aim, squirted it between the stone and my face, and we soon had the encumbrance removed. With it came away a piece of the skin of my tongue, as large as a silver quarter. This escapade was wholly inexcusable, as I had already had sad experience in handling naked guns with bare, moist hands, and all my weapons were wrapped in buckskin, with only the sights exposed.

Our teams were now so exhausted that several of the dogs dropped out entirely, to crawl 
along after us as best they might. Looking back, from time to time, I could see them trying desperately to keep up, for they seemed to know that their only chance of life was to reach the camp before night, to get some of the dog-food, which was running very low. They were quite useless in the collar, for they not only did not draw, but held back the other dogs who were able to pull. I had started with fourteen good, strong animals, but now was reduced to eight; and even these looked like skeletons. However, these eight were game to the backbone, and would 'pull till they fell dead in the harness. " Old Red," still my right-hand dog, would occasionally look over his shoulder with pitiful eyes when I called, "Hyuk, hyuk!" and then he would put down his head and strain at his collar, while his breath came in coughing gasps. The ravens followed us for the last five days, seeming to know that if the dogs gave out they would have a feast. As for us men, we were in no danger, for we could easily have walked to the coast. At last, one memorable day, we dragged ourselves to that last summit, and there, before us, were the waters of the sea, stretching out far to the east, with the pack-ice extending fifteen miles out from the shore. Below us, ten miles away, we could see the black dots that stood for the "hour-glass" huts, where we knew there was 

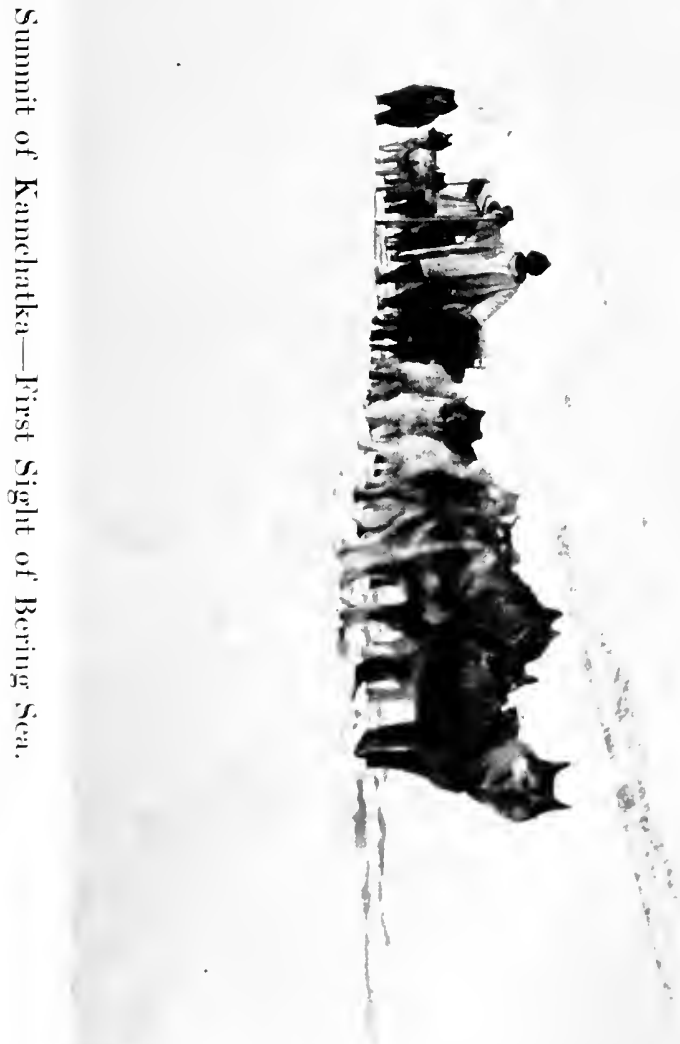
warmth, food, and rest for ourselves and our dogs. Since that day I have been able to sympathize keenly with Xenophon and his ten thousand, when they caught sight of the waters of the Euxine, and raised that glad shout of "Thalassa, thalassa!"

Though the dogs were very weak and worn, we went in with a rush, as usual. But the moment we stopped, the poor fellows dropped in their tracks and went to sleep, without a thought of food. Their utter exhaustion was due to the fact that for the last ten days we had been crossing a stretch of uninhabited country, and it had been impossible to secure for them the necessary amount of food.

We were much relieved to find ourselves once more in "civilization," and we were in no hurry to move on. The people received us so hospitably, and with such genuine kindness, that we spent a week with them, resting and getting the dogs into condition again. Every day we were regaled with frozen fish, dried fish, dainty bits of walrus blubber, and frozen blueberries.

Some of the people of this tribe have curly hair, a thing that I had not seen before in Siberia. They speak with one of those peculiar "clicks" that are so baffling to the Western tongue, and which I had always supposed were confined to the languages of Africa. 
The village was composed of a mixed race in whose veins was mingled Tchuktche, Korak, and Kamchatkan blood, in about equal proportions.

On our second day there I was glad to see the dogs that had dropped behind dragging themselves in. They were tied up in their old places, and fed generously on seal blubber and hot fishsoup, which might be called a kind of fish and oil chowder. They were all suffering badly from the need of fatty foods, and it was interesting to see the avidity with which they would bolt huge pieces of clear blubber. At the end of our week of rest, they were all fat again, their feet were healed up, and they were eager for the road once more. Some of the dogs that had shown less endurance than the others were traded off and better ones secured. The best medium of exchange seemed to be the little skeins of sewing-silk which I had been careful to bring. Skeins that were bought in Vladivostok for two and a half cents apiece readily brought a dollar here. I would have sold it cheaper, but they pushed the price of the dogs up from five dollars to twenty, and I was obliged to follow suit. The silk was in all the colors of the rainbow; it was a study to see the faces of these natives as they devoured the gaudy stuff with their eyes, especially the women. They use the silk to embroider the bottoms of their fur 
cloaks, some of which arc true works of art. Traders have been known to pay as high as two hundred dollars for a single coat. The amount of needlework on them is simply enormous. Sometimes they cut out little pieces of skin a quarter of an inch square, of all colors and shades, and make a genuine mosaic of them, and around the bottom of each garment is a wide fringe of silk. The natives laughed at the prices that I asked, and good-naturedly expostulated with me, saying that they could get the same thing in Ghijiga much cheaper; to which I laughingly answered that they were at liberty to go and get it. Whenever I left a house, I presented the women each with a few needles, which in that country is a very substantial tip.

This village was not composed of pure 'Tchuktches, and these mongrel people are looked down upon by the clean Tchuktche stock, who frequently raid them and carry off their bestlooking women.

It was now my purpose to turn south along the coast, and examine the beach sands and the rivers running into Bering Sea, as far down as the neck of the Kamchatkan peninsula, or Baron Koff Bay. As I was still in a sandstone country, there seemed little likelihood of finding gold in the beach sands, and unless the geologic formation changed as I went south, I 
should push right on without stopping, except to rest.

Bidding good-by to the friends who had treated us so kindly, we set out one morning, on our way southward, keeping to the smooth snow just above the beach line. Once, and only once, I tried to shorten the journey by crossing an arm of the sea on the ice. Here I had my first taste of what it must be like to attempt to reach the Pole across the frozen sea. Not once could I go fifty feet in a straight line. It was an unspeakable jumble of hummocks and crevasses. We covered eight arduous miles that day, and the dogs were so exhausted that we had to stop two days to recuperate. Time and again, that miserable day, I got into the water up to my waist, which necessitated an immediate change of clothes. About once an hour the dogs would fall into the water and have to be hauled out, after which a tedious detour would be made to find a more likely route across the wilderness of ice.

The sixth day out we reached Baron Koff Bay. It is a long, narrow inlet lying southeast and northwest; and at its head I found the little Korak village where it was decided that I should secure a guide to take me to the sulphur deposits, which were supposed to exist in an extinct volcano in the vicinity. These people were of 


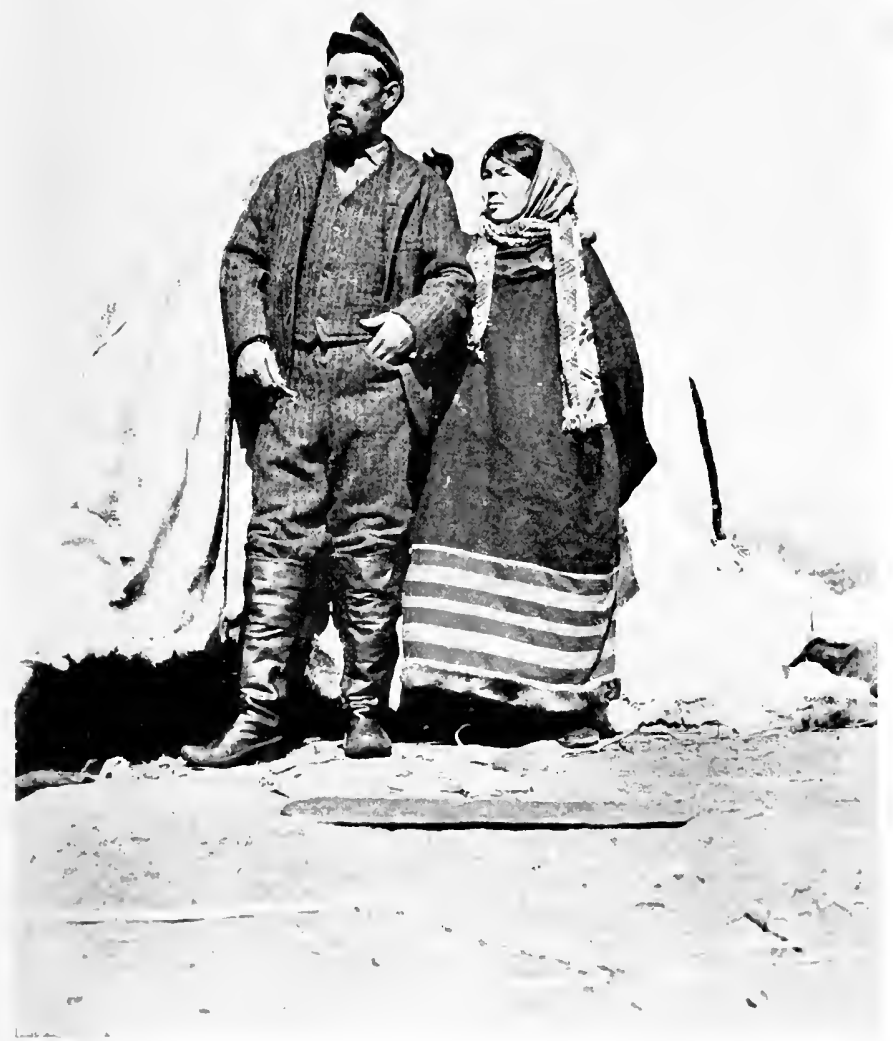

Kassegan, half-easte Russian trader. and Korak wife. living at Bocta. Baron Koff Bay. Kimchatka. 


\section{.}


the same mixed blood as those of the village I had so lately left, but they did not live in the hour-glass houses. 'They simply had the underground room, with a hole leading down into it. The one I entered was fifteen feet wide by ten in height.

In this village seal-catching is the principal pursuit. The seal is such an important animal to these people that they go through a peculiar ceremony every year in its honor-a ceremony. that is characteristically childish and built upon superstitions.

Near this point is an immense deposit of coal which had been discovered by a Russian man-ofwar some twenty years before. The coal is of poor quality, but could be used for steaming if necessary. The coal-measures come right down to the water's edge. In the cliff beside the water I found three veins of coal, with an aggregate thickness of eighty feet.

This was a "dog" village, as distinguished from a "deer" village, and it was amusing to see half a dozen dogs lying about each of the entrance-holes of their underground houses, with their heads hanging over the edge, so that they could better appreciate the smell of food that rose with the smoke of the fire below. Of course I was always on the lookout for good dogs, and while I was in this village I came upon the finest 
specimen of a Siberian sledge-dog that it was ever my fortune to see. He was tawny or lightbrown in color, with a splendid head, back, and shoulders. Clean-limbed, muscular, and straighteared, his tail curved up over his back in the most approved style. He whipped our best dog in less than a minute. His name was Konikly, meaning "One of Two," and his stuffed skin can be seen to-day in the American Museum of Natural History. I presented him to the Jessup Expedition, in charge of which was Mr. Buxton, whom I afterward met in Vladivostok on his way to the north. I tried to obtain this dog, but found, to my chagrin, that he had been marked for sacrifice, and could not be bought. After bidding in vain up to fifty dollars in tea, sugar, and silk, I came to the sad conclusion that the animal was not on the market. But Snevaydoff, my right-hand man, said to me in Russian, "There is a better way. We must simply take him and leave behind sufficient compensation." This, of course, I hesitated to do until I found that the natives would gladly sell him, but did not dare to do so, for fear of angering the deity to whom he had been vowed in sacrifice. If, however, we took the dog by force they would not be to blame, and could demand the price as compensation. So I left the matter with Snevaydoff to arrange as diplomatically as he could. 
We waited a day or so for a Korak named Myela, who was to guide us to the sulphur deposits, and when he arrived we made ready to start the next morning. Everything was loaded the night before, and some time in the night my Korak drivers hitched up the dogs, taking Konikly with them, and drove out of the village. When morning came, the owner of the dogs seemed much surprised to find that his dog was missing, and he very naturally surmised that my men had taken him. He demanded that I should pay for the stolen animal. Of course I protested, but in the end paid the full price, and then every one was happy and satisfied. After these ethical gymnastics, we drove out of the village, and made our way southward to the mouth of a river near which point the sulphur deposits were supposed to be; but I found, to my disgust, that the place was twenty miles inland, up an unnavigable river, and through a very rough country. I saw at a glance that it could never be a good mining venture, but I determined to go and examine the deposit, in order to be able to give a thorough report of the case.

That night we arrived at Myela's home, which was an isolated house or hole in the ground. For the last twelve miles we had been gradually ascending the valley, and the next morning we saw, eight miles away, the extinct crater in 
which the sulphur lay. We unloaded the sledges, and, taking only our picks and shovels, found our'selves, two hours later, on the summit of the volcano. The crater was partly filled with snow, but on one side, where it had been wind-swept, it was not deep. We carefully descended the steep side of the crater until Myela stopped us, and said, "Dig here." After going down through six feet of snow to the ground I found it strewn with detached boulders, covered with a thin film of sulphur, evidently a late solfataric deposit from the crater which had been lately active, and the indications did not promise large quantities; but even if the deposit proved to be rich, I could see very well that mining it would never pay. The distance from the coast, the roughness of the country, and the complete absence of timber made it out of the question. A careful examination of the place was, therefore, unnecessary.

I was then ready to $\mathrm{s}^{+}$art for Cape Memaitch, on the western coast of the peninsula, but I perceived that if I went all the way back to Baron Koff Bay to make a new start, considerable time would be lost. One of my Koraks was tired of the trip, and insisted on going back home by the shortest route, rather than by way of Cape Memaitch. He absolutely refused to cross the range of mountains, as the spring sun was now. 


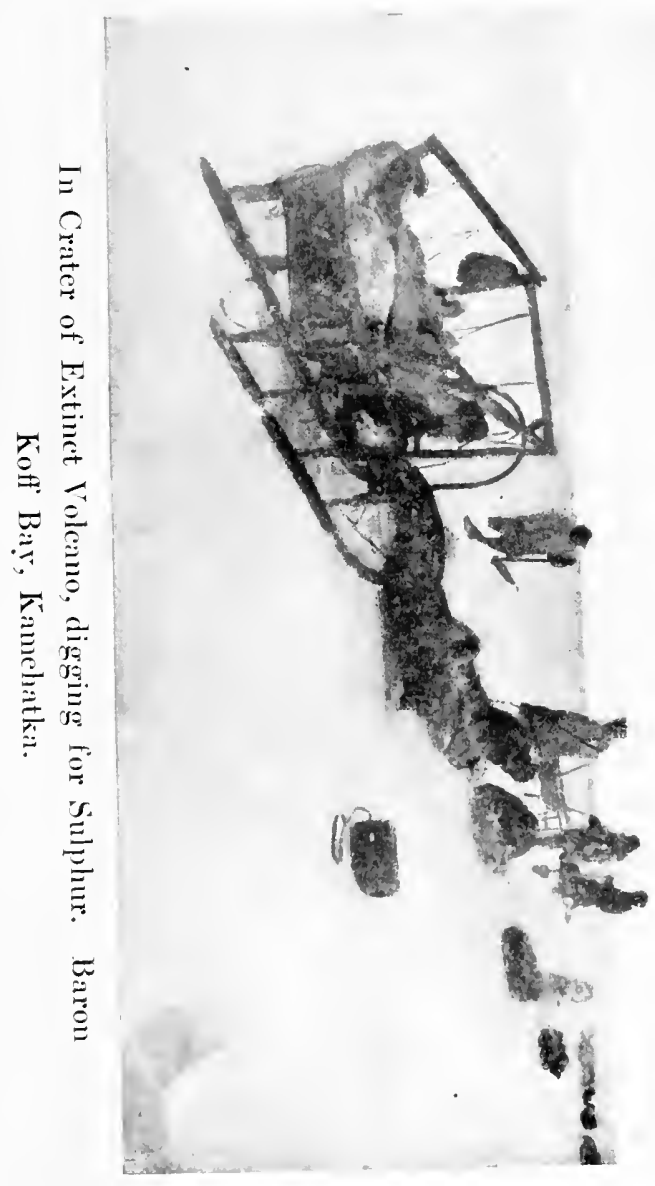



beating down on the snow, and he feared that, at any time, we would be engulfed in an avalanche. I had already learned that this route would not be really dangerous till three weeks later, and that if we pushed right through we should be quite safe. So on the morning of starting I sent off the other Korak with one of the sledges, and then turned to the unwilling one and asked whether he would go with me over the mountains. He still said no. I drew my revolver, and told him that his only chance of seeing home again was to hitch those dogs up instantly and obey me to the letter. He stood for a moment looking into that compelling muzzle, and then turned, sullenly, and began harnessing up. I had no more trouble with him after that.

Two reindeer sledges were engaged to show us the way across the mountains, and to break the track wherever necessary. They started a mile in advance, so as to keep out of sight of the dogs. It was easy work to follow, for it was simply an all-day chase for the dogs; each one had his nose to the ground, and was fondly imagining that he would soon enjoy the unparalleled delight of jumping at a reindeer's throat.

Myela led us before night to a Korak village of three yourtas. As we approached it I saw a crowd huddled about something on the ground. It proved to be a middle-aged woman, lying on 
a deerskin, and she seemed to be dying. I asked why they did not take her inside, and was told that she had asked to be brought out. I studied her symptoms, and decided that she was suffering from the grippe, and that her case demanded heroic treatment. She had not slept for three nights, so I gave her twenty grains of quinine, two cathartic pills, and one-tenth grain of morphine. She woke up the next morning with her eyes brighter, and feeling better in every way. I gave her ten more grains of quinine, and that afternoon she sat up, and dipped her hand into the dish of meat and "spinach," and ate her full share. I thought her cure was something of a triumph, for when I saw her she seemed to be in articulo mortis. As I was about to leave, the husband of this woman, a man of many reindeer, asked me if I had not forgotten something, and intimated that I had not paid for the meat that my dogs had eaten. I asked him if he did not think that my curing of his wife was compensation enough; nevertheless, I paid him his full price and departed. My Korak men told me later that the old fellow was angry because I had saved the woman, as he had already picked out a young and pretty girl to be her successor. Alas! I had unwittingly come between man and wife, and had wrecked (at least his) domestic bliss. On the whole, I am not sure but that it would have been kinder to have let her die. 
Our way led up a succession of cañons, and then over high mesas until we reached the summit of the range. As we were passing up through these cañons, we frequently ran under the edges of enormous overhanging drifts, and I looked up anxiously, but nothing fell except a little light snow and a few small pebbles. After passing the summit I determined to take no chances at all, and so restricted traveling to the night-time, when, of course, everything was frozen stiff.

It was now well into April, and the sun was climbing up into the heavens at noon. The surface of the snow grew a little too soft to make day travel quite comfortable. On this side of the mountains I found considerable float coal, especially in the beds of the creeks. The whole country was a sandstone formation, which, of course, meant no gold. At last, far in the distance, we saw the blue waters of the Okhotsk Sea flashing under the rays of the western sun, and we came down rapidly to the shore. I saw below us a few of the hour-glass huts, and at the mouth of a shallow stream a long promontory running far out into the sea. This was Cape Memaitch,-whither I was bound because the Russians had heard reports of a United States schooner touching at this point and taking away full cargoes of ore to San Francisco.

The first question I asked was whether or not 
it was true that such a vessel had actually stopped there, and was answered in the affirmative. A villager offered to guide me to the spot from which the ore had been taken. I was naturally elated, for there was now a prospect of finding something that would benefit my employers. The next morning we started out along the shore. The guide led me to the face of a sandstone bluff, and said, "Here is the place from which they took the ore." To say that I was dumfounded would be to put it mildly. When I had recovered sufficiently to fairly get my breath, I asked why this stuff had been loaded on the vessel, and the guide calmly replied that it had been done to keep the ship from turning over. It appeared that the vessel was a Russian, and not an American, after all. This place had been a favorite rendezvous for traders, and the schooner had come to exchange the products of civilization for the skins offered by the natives. Of course, when the vessel was unloaded it was necessary to secure ballast, and for this purpose the sandstone had been brought into requisition. I shrugged my shoulders, and tried to take it philosophically.

Our next move was to start on the return trip around the head of the Okhotsk Sea to Kaminaw. We had a beautiful road over the smooth tundra. Konikly was now leading with "Old 


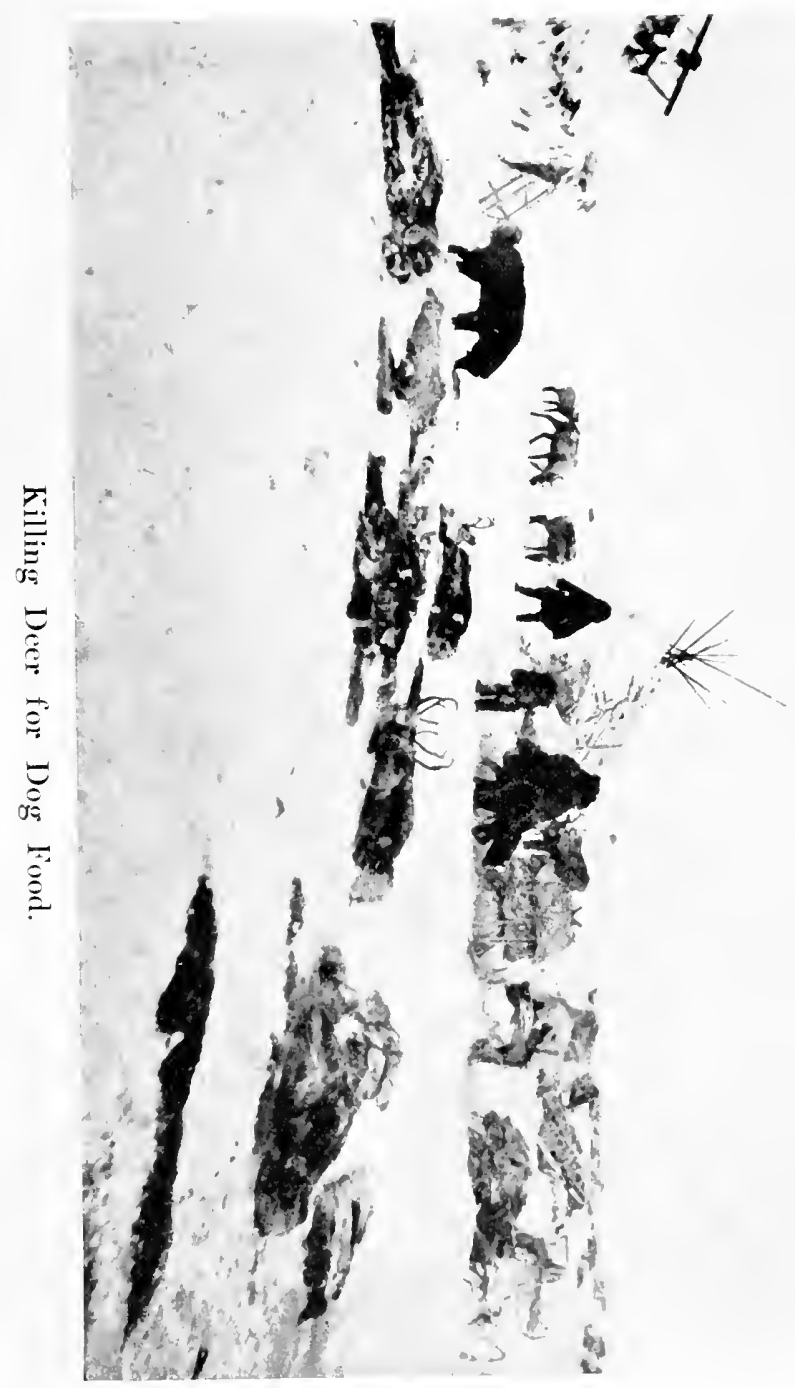



Red," and every time we stopped, the two would fight, for the latter was very loath to share my affection with Konikly, whom he considered a parvenu.

As we were speeding along the beaten track the Koraks would break out in a wild strain of music; then Snevaydoff would sing one of the Russian peasant-songs, and oceasionally, not to be outdone, I would give them a few bars of some such touching lyric as " A Hot Time," or "After the Ball." 'Thus we whiled away the long hours on the road.

Every few hours we changed places, letting each team lead in turn, for only the driver of the head team had any work to do. 'The others could even lie down and go to sleep if they wished, for the dogs drew as steadily and as patiently as mules. It seemed second nature to them. I used to sit and wonder how they could be trained to undergo such severe labor. I found out that, when only four months old, they are put into the hands of the small boys to train. They make up little teams of pups, with the mother dog, perhaps, as leader, and bring in water from the neighboring stream or drag in the firewood. By the time they are a year old they are ready to be turned over to a grown-up, who hitches up one or two of the young dogs with some steady old fellows, and it is not long before the 
training is complete. This method not only trains the dogs, but it teaches the boys how to handle them, so that by the time they are young men they are expert drivers.

After several days of fine going we arrived at Kaminaw, where I found the Ghijiga magistrate, who had come on his annual collecting tour. Each of the Koraks pays an annual poll-tax of four and a half dollars' worth of skins. These are taken to Ghijiga, and there auctioned off to the highest bidder. All these northern natives pay this tax, except the Tchuktches, who refuse to pay a cent. I found the magistrate in one of the huts, reclining on several bearskins, and kindly and affable as ever. Over him was arranged a sort of canopy to protect him from particles of dust or dirt that might fall from between the rafters of the building. He was dressed in his full regimentals of green and gold, with a sword at his side. He gave me a fine cup of coffee, and made me take a pound of the fragrant berry to cheer me on my way in to Ghijiga. I jealously guarded it, and made the grounds do duty three or four times over till every particle of the caffein had been extracted. 


\section{CHAPTER XV}

\section{A PERILOUS SUMMER TRIP}

The tundra in summer-Crossing the swift Paran RiverLiterally billions of mosquitos-Unique measures of protection against these pests - Mad race down the Uchingay River on a raft-Lighting a fire with a pistol-Narrow escape from drowning-Fronyo proves to be a man of mettle-Pak is caught stealing from slim supply of provisions and receives chastisement-Subsisting on wild onions and half-ripe berries-Help at last.

F'TER a rest of two days we started out on
the home stretch toward Ghijiga, which lay three hundred miles to the southwest. As the snow was now very soft the wooden runners of our sledges were useless. The wet snow stuck to them, and made progress almost impossible. We therefore purchased sets of whalebone runners, cut from the ribs of the whale, and pared down to a quarter of an inch in thickness. These strips are pinned to the sledge runners, one piece overlapping another, and the joints worked down smooth. These are as good on wet snow as the iced wooden runners are on dry snow. We made the three hundred miles in four days, which was doing 
fairly well, considering the fact that we came back with only half the number of dogs that we started out with. It is true, however, that we had made one or two valuable acquisitions in the dog line, especially Konikly, with whom I became more and more pleased. We fed the dogs on the best the land could provide, and kept them on the road from twelve to fourteen hours a day. Our provisions were, of course, almost gone, and we were coming back practically as "empties."

In making long trips the natives frequently have to cache a part of their provisions along the way for use on the return trip. They make a little scaffold on the stumps of trees or between two or three living trees. Even though not set up very much above the snow line, the snow is so deep that by the time summer has melted it away the goods are high and dry. No one except the owner would ever think of touching these provisions.

Upon my return I found that the snows were fast melting, and green tints were beginning to appear on the hillsides. I thought, however, that there would be enough snow to allow me to take a little run down the peninsula that lies between the two northern arms of the Okhotsk Sea in search of a deposit of cinnabar of which $I$ had heard rumors; but after two days of hard work, urging the dogs over bare tundra, I gave it up and came back in disgust. By June 1 the snow was quite 


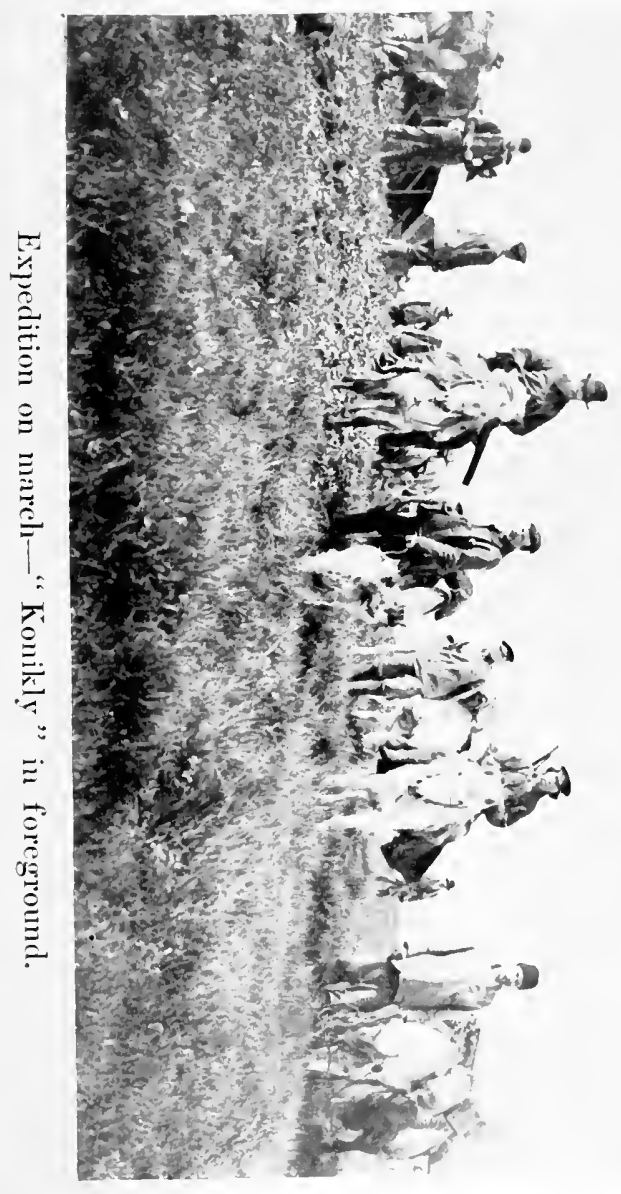



gone, except upon the highest hills and in the secluded nooks where deep drifts had lain. The river was still very high, and filled with floating ice. The sun was now visible twenty hours out of the twenty-four.

I was soon ready for a summer trip. The services of my old friend Chrisoffsky and half a dozen of his horses were secured, and, taking along my two Koreans, who had wintered at Ghijiga while I was making my trip to the shores of Bering Sea, I started out, sitting in the saddle which had been left in the village thirty years before by Mr. George Kennan. He was then a leading spirit in the American Russian Telegraph Company, whose object was to build a line across Bering Strait and connect the two continents. Of this saddle there was nothing left but the tree and a little leather on the cantle, bearing a San Francisco stamp. Mrs. Braggin said that Mr. Kennan had given it to her when he left; I rigged it up with stirrups and used it all summer.

Plodding northward, we reached Chrisoff sky's place about bedtime, soaked with mud and water. The tundra was like a great marsh, through which we had to flounder. We tried to keep to the beds of the little creeks in which the water had worn away the moss and turf. Where this was not possible, we had to wade through almost 
bottomless mud. Even though lightly loaded, the horses kept sinking to the girth, and it was only by sheer hard work that we were able to average fifteen miles a day. Some days we made only five.

Our objective point was the Uchingay, which means "Red," River. It is a comparatively small stream, flowing into the Paran, near its head. The natives had told me that at the head waters of this stream there were two red mountains where the rocks were filled with shiny yellow points. This place lay about three hundred miles north of Ghijiga.

As we neared the foot-hills the trail became better. The tundra was one mass of brilliant flowers, like the wrecks of rainbows. There were plants of almost infinite variety, and the ground was like a great expanse of variegated carpeting. But the flowers! They were indescribably beautiful. Turning the shoulder of a hill, we would come upon a broad expanse of solid pink or scarlet, acres in extent, and this would give way to a blue, a yellow, or a lavender, either in solid color or in various blends. We enjoyed these beauties of nature, but, at the same time, did not fail to notice the fine beds of wild onions, which we pulled and ate with great gusto. We craved vegetables in summer as keenly as we had craved fat in winter. Hardly an hour passed that we did not have 


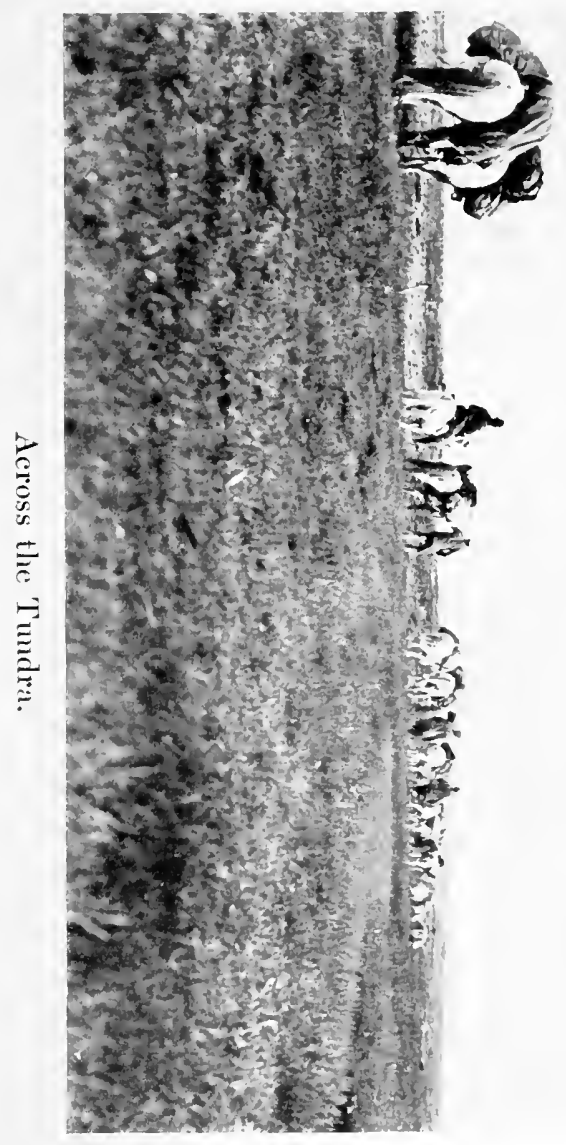


a shot at a duck or a goose, and our journey was consequently a continual feast. Konikly and Howka accompanied us. 'They lived like princes on the tundra rats, which swarmed about us. The dogs caught them cleverly, and after one good shake, bolted them whole. These modents were the size of a small house rat.

On June 22 we crossed the high pass leading into the valley of the Paran River. My aneroid showed an elevation of six thousand feet. That afternoon we were greeted with a storm of sleet and snow, which drove us to the shelter of a high precipice, where we stayed close till the following day. The descent once fairly begun, we soon came into a more genial atmosphere. Below us in the valley we could see the heavily wooded banks of the Paran where Chrisoffsky and his two sons were to leave me with my two Koreans and Fronyo, the Tunguse guide. That night we camped on the bank of the river.

We were now in the primeval wilderness and had to subsist off the land. There were fish to catch and there was game to shoot, so there was little danger of our coming to grief. We had with us some fish-nets. These were made of horsehair obtained by barter from Central Siberia. These nets are large enough to hold a goodsized salmon. By placing them at the mouths of little creeks, and then scaring the fish down 
into them, it was not difficult to secure pleńty to eat.

The Paran, even on its upper reaches, was a formidable stream two hundred yards wide, at this season swollen by melting snows. It was imperative that we cross this river, for the Uchingay flowed into it from the other side. Old Chrisoffsky had averred that I would never get across alive, but $I$ had assured him that I could if there was timber near by. I had already guaranteed to pay for any horses that I might lose during the trip. When we came down to the bank of the river and saw the swift, sullen tide, the old man laughed and said, "I told you so." I knew that he would be an impediment to me, and that he would do all he could to prevent my taking the horses across, so I answered that as it was impossible to cross I would go into camp and wait for the water to go down. The old gentleman hit the trail for home the next day, carrying the tale that for once the American was beaten, and must await the pleasure of the Paran River. He would have been surprised had he seen us that very night safely on the other side with our baggage and horses intact. I confess the crossing was no easy feat, but it had to be done. As the river narrowed to a gorge with dangerous rapids less than a half mile below where we stood, I went three miles up the stream, where I found a lot of dead 
trees, averaging some ten inches in thickness. These we felled and cut into twelve-foot lengths, and bound them together with walrus rope, and thus were provided with a good raft. 'The Tunguse with his ax fashioned four rough sweeps, and we rigged up rowlocks by mortising uprights into the side logs of the raft.

We first tried, unsuccessfully, to cross by swimming the horses behind the raft; the animals kept trying to climb upon the raft. So we put back to shore. Then, making long whips, we drove the horses into the water at a point where the current set across toward the other bank. By vigorous whipping we showed the horses that they were not to be allowed to come back to the shore. They were swept off their feet, and after one or two attempts to return they seemed to understand the situation, and set out for the farther shore, which they reached after being swept about a third of a mile down-stream. 'Then we shoved off and arrived without mishap on the other bank at almost the very spot where the horses had landed, and we found them quietly eating.

It was now late in June, and the mosquitos had arrived in full force, though the flies as yet held off. The former pests were so thick that the air seemed literally filled with them as with flakes of snow in a heavy storm. 'The air was resonant 
with the deep humming sound from their wings. We all had to wear heavy gauntlet gloves tied tightly about the arm, and mosquito-hats made after a plan of my own. The summer before, I had made use of a broad felt hat with mosquitonet sewed around the rim, and with a draw-string at the bottom to fasten it at the throat; but this had proved perfectly useless because the least breath of wind would blow it against my face, and instantly a hundred mosquitos were at their deadly work. Besides this the net was continually getting torn in the underbrush; consequently, I was driven by desperation to invent some better way. I had with me a small roll of fine wire screen for screening gold ore. It was "thirty-mesh" (thirty strands to the inch). The night after we crossed the river $I$ got out this roll of screen and cut out pieces six inches wide and twelve inches long and sewed them around the front rims of our hats. I cut up a couple of flour-sacks and sewed the strong cloth all around below the wire screen and behind the hat, gathering it with a string at the bottom. Finally I punched a small hole through the wire for my pipe-stem, and with this piece of armor on my head I could laugh at the mosquitos, and even succeeded in drinking tea through the screen.

When we ate we were obliged to make a big smudge and sit in the smoke, and we slept in our 


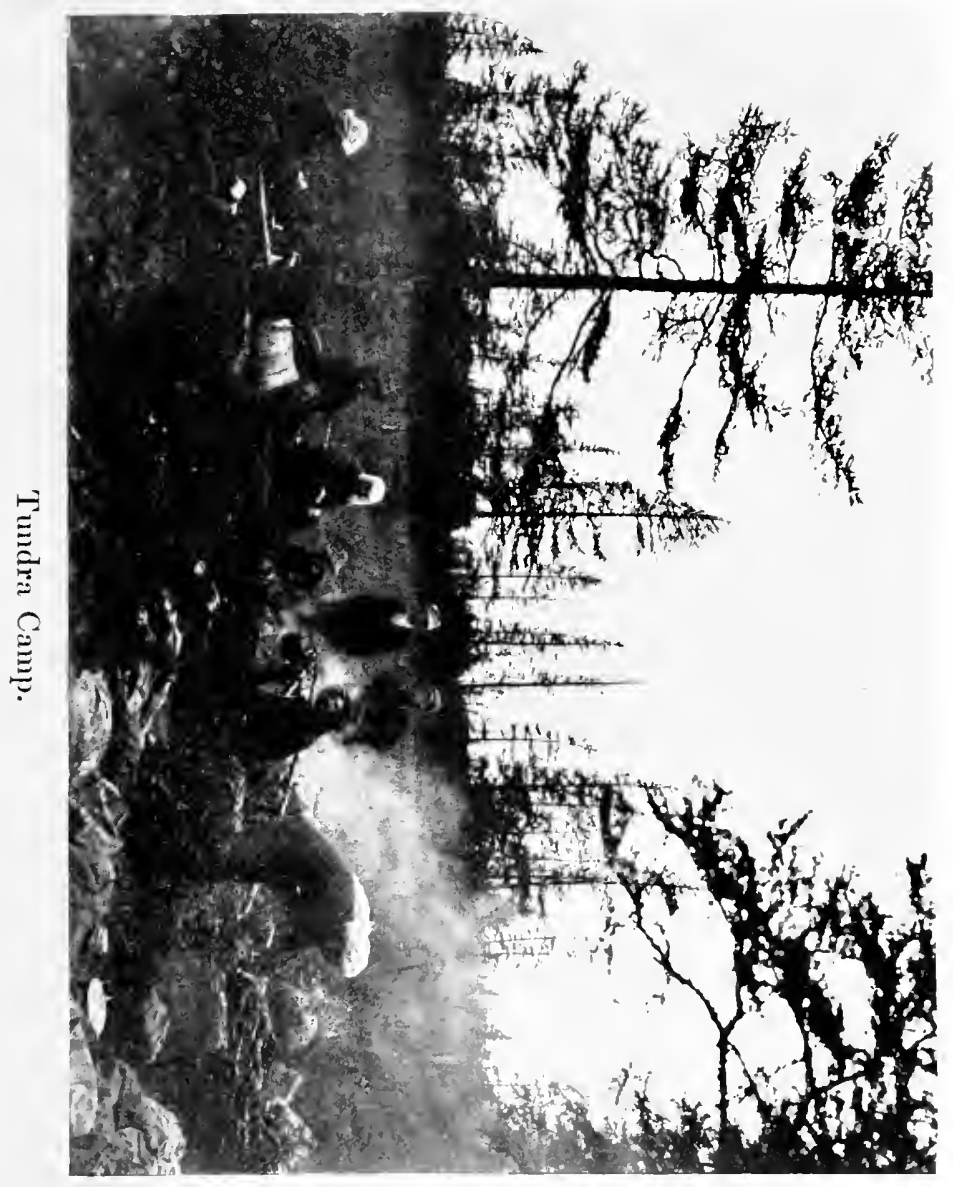



hats and gloves. The special value of the wire screen became evident a few days later when the flies began to appear. There was one species of fly so small that it could easily penetrate the ordinary mosquito-netting, but could not possibly: negotiate this wire screen. The bite of this fly feels like the prick of a red-hot needle, and two days later each bite becomes a running sore. The flies are far more to be dreaded than the mosquitos.

The poor horses were simply black with mosquitos, though we helped them as much as we could by tying branches of leaves to the saddles and bridles. During the night we provided a good heavy smudge for the animals to stand in. The horses knew well its value, and would crowd together into the smoke to escape the cruel stings of their enemies. At about four o'clock each morning the cool temperature quieted the mosquitos, and the horses could get two hours of feeding. At noon, when we lunched, the horses would crowd in upon us in the smoke, and even though beaten off, would persistently return. Frequently the camp was pervaded by the smell of burning hoofs and tails. The dogs suffered less, for their hair protected them, and at night they. would sleep with their faces buried between their paws so that the mosquitos could not get at their vulnerable spot. 
Having crossed the river, we followed along its eastern bank till we came to the Uchingay River, and a few days later reached the head waters of this stream. We saw in the distance the two red mountains. In the stream I began to find floatrock containing iron pyrites, and I prospected carefully on all sides, but, with the exception of a few colors now and then, there was nothing of interest. When we came near the source of the stream I sunk shafts to bed-rock. After a thorough examination of the region I was forced to admit that the trip had been a failure, and prepared to retrace my steps.

After two days on the return trail, we found the water of the stream fairly deep, and I determined to make a raft and float down with my Tunguse guide, examining the outcroppings on either side of the stream, while the two Koreans took the horses down along the bank. I estimated that I could go four times as fast as the horses, and that if I stopped frequently to examine the formations I would arrive at the crossing of the Paran at about the same time as the Koreans.

So we all went to work and made a raft of light dry sticks, twelve feet long by about eight inches in diameter. There were twelve sticks in all, and the raft was about seven feet wide. Fronyo selected three good pieces of timber and made sweeps, the extra one being for emergencies. We 
also had two good stout poles. All our baggage was loaded on the raft, fastened down securely, and covered with a tarpaulin. I then divided the food evenly, giving the Koreans their full share, and telling them to go to the point where we had crossed the Paran, and that if we did not show up within a certain time to make their way across the river and return to Ghijiga without us. I gave Kim the rifle and cartridges, and half the food, which amounted to a little rice, half a pound of tea, and some hard bread. I also gave him the fish-net. Fronyo and I kept the shot-gun.

We bade the Koreans good-by, and shoved off: into the stream, which was running like a millrace. We were kept busy steering the raft clear of the rocks with which the river was strewn. As yet we used only the poles. I may as well confess right here that this trip on the raft was a fearfully hazardous undertaking, for we never knew what sort of water we had below us; so clumsy was our craft there was no chance of escape to either bank should danger loom suddenly ahead. But the hard work we had experienced in making our way through the tangled woods made us reverse the dictum of Hamlet, and, rather than bear again the ills we had been through, we flew to others that we knew not of. The rush and swirl of the angry waters, the narrow escape from the ragged crest of a reef that came almost, but not quite, to the 
surface, and was invisible thirty feet away, the rush past steep cliffs and flowery banks, all formed such a delightful contrast to the weary plodding through the forest that we were willing to welcome almost any dangers for the sake of the exhilaration of this mad dash down the stream.

The river was only about twenty yards wide at the point where we embarked upon it, but it broadened rapidly as it was fed by tributary streams from either side. Now and again the current was divided by an island, and then came together far below. All went smoothly the first day, and at four o'clock we tied up to the bank and prepared to camp. But so great was our difficulty in finding any dry wood that it was bedtime before we had finished our preparations for the night.

The next morning we made an early start. It was thought that we must be near the junction of the Uchingay and the Paran. Though a drizzly, sleety day, it did not dampen our ardor-nor that of the mosquitos. I had to put on a set of oilskins which greatly hampered my movements on the raft. The river had now broadened to a hundred and fifty feet, and was indeed a mighty torrent. We tied up to the bank frequently to examine the outcroppings.

We had congratulated ourselves upon the ease and rapidity of our run down-stream, when sud- 


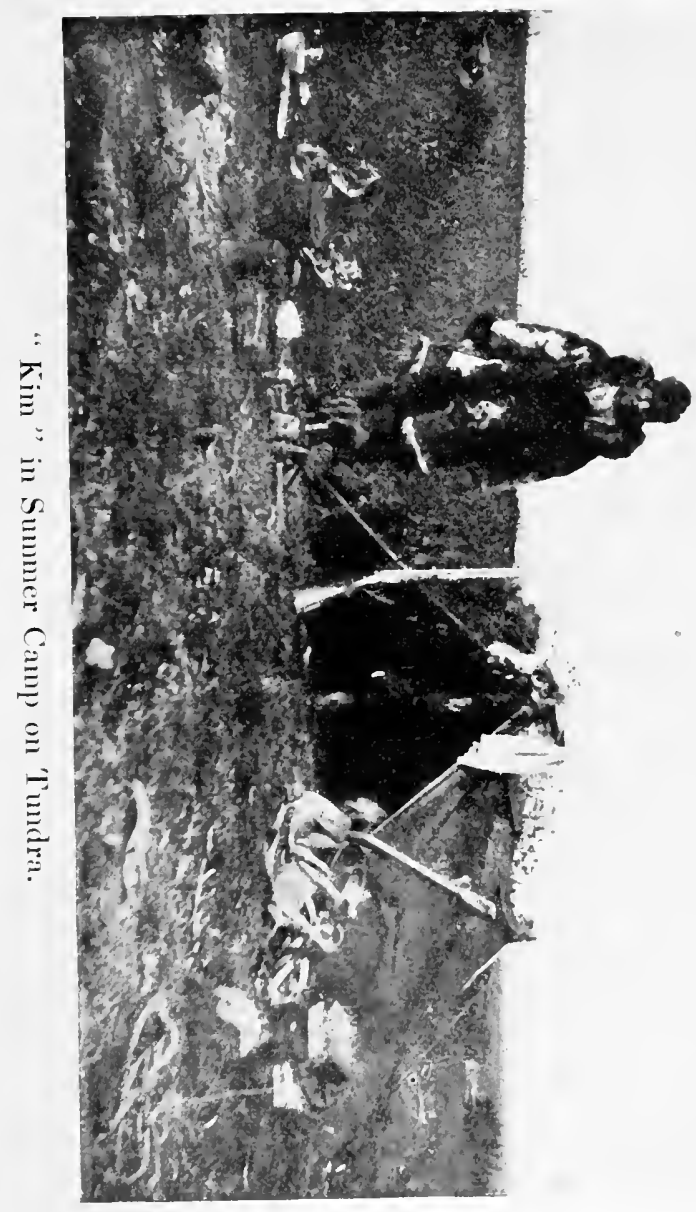



denly we sighted white water below and knew there was serious trouble ahead. Our raft was so light that usually it would pass over any obstacles in the bed of the stream or at most scrape lightly upon them, turn around once or twice, and then float off into smooth water below. Of course, if the rocks came above the surface it was an easier matter to go around them. We managed to pass through these rapids successfully, but immediately below them we saw that the stream divided into two parts, the channel to the left appearing to be the better one. We guided our raft accordingly, and soon found ourselves rushing down a gorge at railroad speed. The cañon began to " box up" in an ugly manner, and our pace became so great that we lost control of our little craft. Sweeping around a bend, we saw that a great tree had been undermined by the water, and had fallen out over the stream so that two thirds of the narrow channel was completely blocked. We strove with might and main to pull the raft to one side in order to evade disaster, but she might as well have been an ocean steamer for all the effect of our futile endeavors. We swept under and among the branches of the tree, and though we hugged the raft as closely as possible, we were both brushed clean off. I seized a branch and tried to draw myself up, but the current snatched me away, and I was swept 
down-stream. I fought to regain the surface, but could not do it. My head was fairly bursting, when I felt the current pushing me up, and suddenly I was shot out of the water and rolled up on a wooden incline. As soon as I could collect my wits I found, to my amazement, that I was on the raft again. It had landed against a rock in a shelving position, with the lower side under the water, and the water itself had provided, in an almost miraculous manner, the means which alone could save my life. Almost the first thing I saw was a hand above the water, grasping the edge of the raft, and another feeling eagerly for a place to get hold. Poor Fronyo was under water and evidently far gone. I thrust my arm in up to the shoulder, and got hold of his hair, and I had little difficulty in dragging him out and up on the raft. He was almost unconscious. I took him by the collar and the seat of the pants, and, by pounding his stomach on the pack, soon relieved him of the water he had swallowed. Twenty minutes later I was rejoiced to see him quite himself again, although very: weak.

When he had sufficiently recovered, we began to think of continuing our eventful journey. The raft was firmly lodged upon the rock, and the force of the current threatened to break it up at any moment. I waded into the water on the submerged end of the raft to ease the pressure on the 
rock, and then, with levers, we gradually swung her about until she drifted free of the ledge and went whirling down-stream.

By good luck we encountered no more obstacles, and soon shot out into open country; and, in a drenching rain, we pulled up to the bank and hastened to make preparations for getting dry. Almost everything we had was soaking wet, but I remembered that among our impedimenta there was a tin box containing some matches. I rummaged around and found it, but the matches were too damp to use. We then hunted every where for a piece of flint, but could find none. As a last resource, I opened my medicine chest and took out a piece of absorbent cotton. Then we secured some dry chips from the interior of a log of dead wood. Opening three or four of my revolver cartridges, I poured out the powder on the absorbent cotton and then fired a blank shell into it. This manœuver proved successful, and we soon had a roaring fire. We stood in the smoke and let our clothes dry while we fought the mosquitos. Now and then we would make a dash out of our covert to bring wood for the fire. In a couple of hours we were dry, and, lighting our pipes, we had a good smoke. We were able to laugh, then, at the ludicrous aspect of what had been a mighty close shave. Fronyo had done better than I, for he had not once loosed his hold on the raft; and yet had I not been swept off and then thrown up on 
the raft again, there would have been no one to tell the story.

'This 'Tunguse, Fronyo, was game to the backbone. When it came time to start out once more on our crazy craft, he crossed himself devoutly, and followed me without a murmur. He said that if God willed that he should die on that raft he would die, that was all. If he did not follow me wherever I went he felt that he would lose caste with his people and be shamed forever.

That day I shot two sea-gulls which had come far inland to nest. 'They were not very savory. eating, being. tough and insipid. These birds usually come up into the interior in May, and, until the advent of the salmon, they have little to eat except berries. Each day they make a trip down to the coast and back.

All our sugar was melted, and our tea had received a preliminary steeping; but we dried it out and made it do. The fact is, we were rather badly off for food. I had only a few paper shells left, and half of these were damp.

The next morning after our adventure in the gorge we cut loose from the bank, and, in an hour's time, floated out of the Uchingay into the Paran, which was a hundred and twenty yards wide, and carried an immense volume of water. 'The river was in flood, and was filled with small islands, which made it difficult to choose a route; 


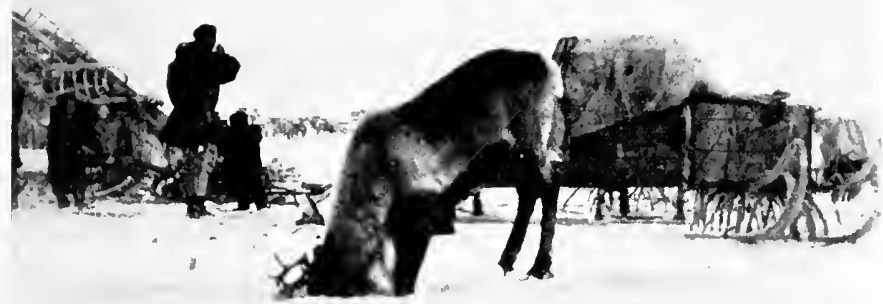

Reinderer Feeding. 

but all went well, and at four o'clock we pulled up to the bank at the spot where we had first crossed, and where we had agreed to meet the Koreans. We settled down in camp, expecting to see them on the following day. That afternoon $I$ had the pleasure of killing a goose with a brood of little ones. After the mother goose had been killed the little ones took to a small pond, but were hunted down and killed in cold blood. It was no time to think of mere sportsmanship, as the law of self-preservation absorbed our thoughts. Soon we heard the "honking" of the old male goose. Fronyo took the dead goose and cleverly set it up with a stick thrust through its neck, and the other end stuck in the mud at the bottom of the shallow pond. The old gentleman goose saw his spouse sitting quietly on the water, and was just settling down near her when, not receiving any answer to his call, he grew suspicious and started to rise again. I could ill afford to waste a single cartridge, but I took the risk and fired. 'The old fellow came to the ground with a resounding thump. We now had over twenty pounds of good meat. Of the little goslings we made a soup, adding a good quantity of wild onions; and it would have been a dish fit for a king had we possessed a little salt. But our supply had been melted.

The next day we heard a rifle-shot in the woods. 
This was the signal agreed upon, and soon Konikly and Howka came running into camp half famished, and eagerly bolted the bones that we had thrown aside. We could not waste a cartridge on an answering shot, so Fronyo went out to meet the Koreans, and soon brought them into camp, and there followed an interesting interchange of experiences since we had parted company on the Uchingay. I found that they had not hoarded their provisions at all, but, with true Korean improvidence, had eaten up everything. For the morrow they had no thought. I took a careful inventory of stock, and found that we had two geese, a little wet rice, some tea, and hard bread. The outlook was certainly not pleasing, for it would take at least six days to get within the radius of civilization.

To recross the river we used the same heavy raft that we had crossed on before, dragging it a mile up-stream before venturing to embark. The horses knew that they were on the homeward trail, and breasted the swift tide willingly.

Before starting out to cross the mountains on the way to Ghijiga, it was imperative that we should supplement our slender stock of food, for there would be several days during which we could hope to get very little along the way. With our small fish-net I tried a little arm of the river, and succeeded in catching two fine harritongas, each 
weighing nearly three pounds. They were black on top, with a yellow belly, and supplied us with a delicious white meat. The dorsal fin extends from the neck to the tail. It is a favorite dish in Russia, where it is called the harra. Try as I might, I could catch no more.

I decided that it would be necessary to send Fronyo on ahead with the best horse and most of the food, with instructions to hurry to Ghijiga and secure from the magistrate the necessary food, and then hasten back to our relief. I wanted certain special articles of food, and as I could not write Russian, and as Fronyo could not be expected to know the different kinds of foreign food, I was driven to use the primitive ideographic method. My note to the magistrate, therefore, consisted of a series of pictures, representing roughly the things that I wanted and the amount. First came a picture of a Tunguse leading a pack-horse, and then the "counterfeit presentment" of a tin of beef, with the number twelve appended. Then came loaves of bread, with tins of butter following, and a noble array of other edibles. To my fancy it was the most interesting procession I had ever witnessed.

Fronyo said that we need have no fear, for if worse came to worst, we could live on the wild onions and the inside bark of the fir-trees, which grew here and there among the mountains, while 
on the tundra there were plenty of tundra ratsappetizing thought! Of course, if we had been in any real danger of starvation, we could have immolated the horses and dogs on the altar of Epicurus, but we did not propose to do this, except as a last resort.

The wild onion is considered the best cure for the scurvy, and is eaten eagerly as soon as it begins to appear in the spring. It is said, though I had no opportunity to see a case, that if scurvy is imminent and some of the wild garlic is eaten, the body breaks out in an eruption which passes away in a few days. The onion seems to expel the germs through the skin by means of this eruption.

The natives strip the birchbark from the trees while it is still green, and cut it into long threads like vermicelli. On entering a village it is quite a common sight to see the women cutting up this bark for food. They ferment the juice of this birchbark and make a mild alcoholic drink. They also eat the berries of the shad-bush and the bark of the sallow, a kind of willow.

These people have acquired a remarkable knowledge of the virtues of various plants. Some of these tribes are accustomed to dip the points of their arrows into a decoction of a species of ranunculus, and wounds so inoculated are incurable unless the poison is immediately drawn 
out. Even whales, if wounded with these arrows, come near the shore and expire in dreadful agony.

Fronyo started out at a good pace while we stayed behind to try and secure more game before hitting the trail across the mountains. We secured two more fish, and at four o'clock in the afternoon were on the road, which we kept till ten o'clock. The next morning, after half a breakfast, we pushed on up the valley through the foothills of the range that we had to cross, none of us any too cheerful, but all determined.

That day I discovered some crumbs of bread in Pak's beard, and investigation showed that he had been making a square meal of a large portion of our remaining small stock of bread. It may be pardoned me, under the circumstances, that I drew off and hit him a good shoulder blow in the left eye, which felled him to the ground. This proved to be an unfortunate form of punishment, for he was the Korean who possessed only one good eye, and that was good no longer. My anger, righteous though it may have been, turned instantly to solicitude. I blamed myself without measure for my hasty action, went into camp and founded a hospital on the spot. For the next twenty-four hours all my energies and resources were centered on that unhappy eye. I can truly say that $I$ have never hit anything since without 
first making sure that the object of my punishment had a spare eye. Later on my conscience forced me to give him a silver watch and a new suit of clothes. I rather think the other Korean envied him that blow when he saw the final result.

To my vast relief the eye healed, and we went on. The third day saw us over the mountains and crawling across the tundra. We had thrown away all our bedding and blankets, and each was astride a horse. On the fourth day we were reduced to wild onions and half-ripe berries, which induced a violent diarrhea. We came at last to where sea-gulls were nesting, but they were so shy that we could not get near them. Konikly had gone on with Fronyo, but we still had Howka with us, and he was getting fat on the tundra rats. It was to him, now, that we looked for food. He would make a rush at a sea-gull, and, as the bird flew from its nest on the tundra, he would begin to devour the eggs; but we would rush up and drive him off and secure the loot. The eggs were far gone, and would have been ready to hatch in another week. We boiled them, and the Koreans ate the embryonic sea-gulls while I ate the albuminous substance that still remained. About this time we began to think of sacrificing one of the horses to the common good, but no one of us was strong enough to walk, and the horses were 


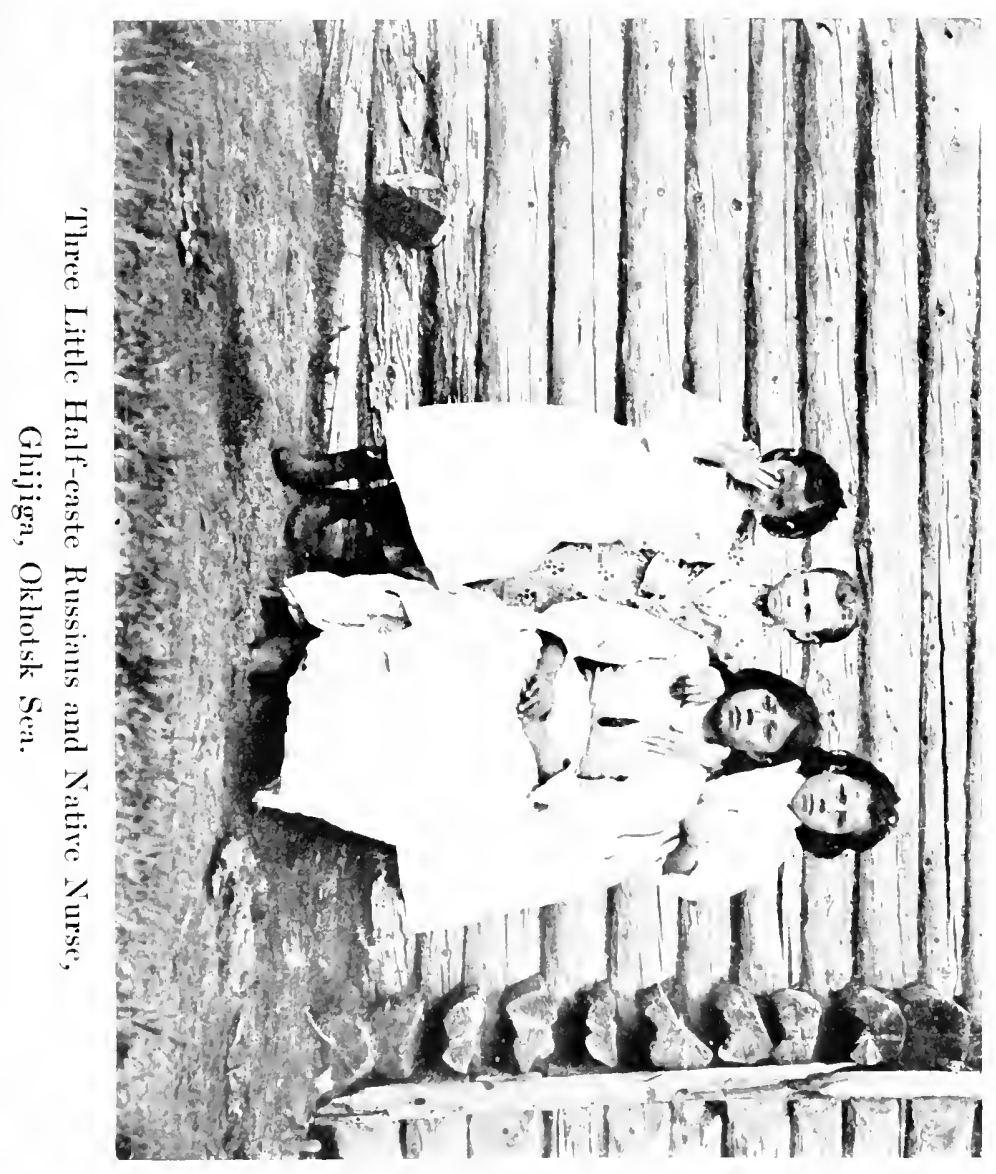



therefore spared. The dog we could not kill, for he was our chief provider.

We plodded on until we were about two days' journey from Chrisoffsky's house, when one morning I descried, far across the tundra, a line of some fifteen pack-horses and men. We spurred on gladly to meet the welcome relief.

I found that half a dozen of the officers and men of the steamer which my employers had sent for me had come to hunt me up. Never have I seen such a glorious sight as those well-dressed men and those loaded horses. The captain dismounted, and I tried to address him in Russian, but he said, "You forget that I speak English." Now, it may seem scarcely credible, and yet it is true, that for a few moments I was almost totally unable to converse with him in my native tongue. I had not used a word of it in conversation for fourteen months, and my low physical condition acting on my nerves, confused my mind, and I spoke a jumble of English, Russian, and Korak. It was a week before I could talk good, straight English again.

We camped right where we had been met, and the packs were opened up immediately. I sat on a sack filled with potatoes, and watched them bring out coffee, then some bacon, then some fresh eggs! Then the captain came with a bottle of champagne and handed me a glass. This I 
held in one hand, and with the other I reached down and extracted a potato, and fell to munching it raw, sipping the champagne between bites, while I watched them build a fire and prepare the food. It was a feast that I shall never forget. After it a box of good cigars was circulated, which added the final touch to my felicity.

When the inner man had been satisfied, I began to think of how the outer man might be improved upon. My clothes were in rags, my weight had fallen from one hundred and sixty pounds to one hundred and fifteen, my beard was long and unkempt, my boots were in shreds. The good friends had thoughtfully brought along my steamer trunk, which now lay in one of the tents. I ordered several kettles of water heated, and stripping behind the tent, I threw the noisome rags, with all their denizens, as far into the bush as $I$ could, and then went in and had a glorious tubbing. I got into a suit of soft flannels, Scotch tweed knickerbockers and a Norfolk jacket, and after shaving and grooming myself for an hour, the loathsome larva that had crawled into camp emerged from that tent a bejeweled butterfly. That delicious moment was worth almost as much as it cost.

Then we made our way back to Ghijiga, where I distributed presents among my friends, native and foreign, and boarded the steamer for Vladi- 
vostok. I reached that place twelve days later, and gave account of my travels and explorations. The search for a Siberian Klondike had been, so far, a failure. This is not the place for a technical account of my observations in northern Siberia, but this much I may say: though there may be gold within the radius that I covered, I satisfied myself that there were no extensive auriferous deposits on the streams flowing into the Okhotsk Sea near its head, nor in the beach sands along the shore of Bering Sea, south of the Anadyr River. But, of course, the whole question was not yet settled, for there remained the whole stretch of the northeast peninsula, above the point I had reached, and it turned out that 1 .xy work was not yet finished. 


\section{CHAPTER XVI}

\section{A TEN-THOUSAND-MILE RACE}

Persistent rumors of gold in the Tchuktche peninsulaCount Unarliarsky - I am called to Vladivostok to fit out an expedition-Our vessel arrives off Indian PointCharging through the ice-floes - A meeting with Eskimos -Our prospecting proves fruitless-We meet the rival expedition in Plover Bay-Their chagrin-The end.

THE winter following my explorations in Northeast Siberia I spent in the United States, during which time the papers contained frequent reports of rich finds on the Siberian coast, opposite Cape Nome. The company that had employed me still believed that there was gold to be found in this region, and were determined to test the matter thoroughly. The papers stated that the Russian Government had granted to Count Unarliarsky the mining rights to the whole Tchuktche peninsula, which is the extreme northeastern portion of Siberia, between the Anadyr River and the Arctic Ocean. From St. Petersburg we learned that the Count must present the papers of his franchise to the Governor at Anadyr before he could legitimately take possession. 


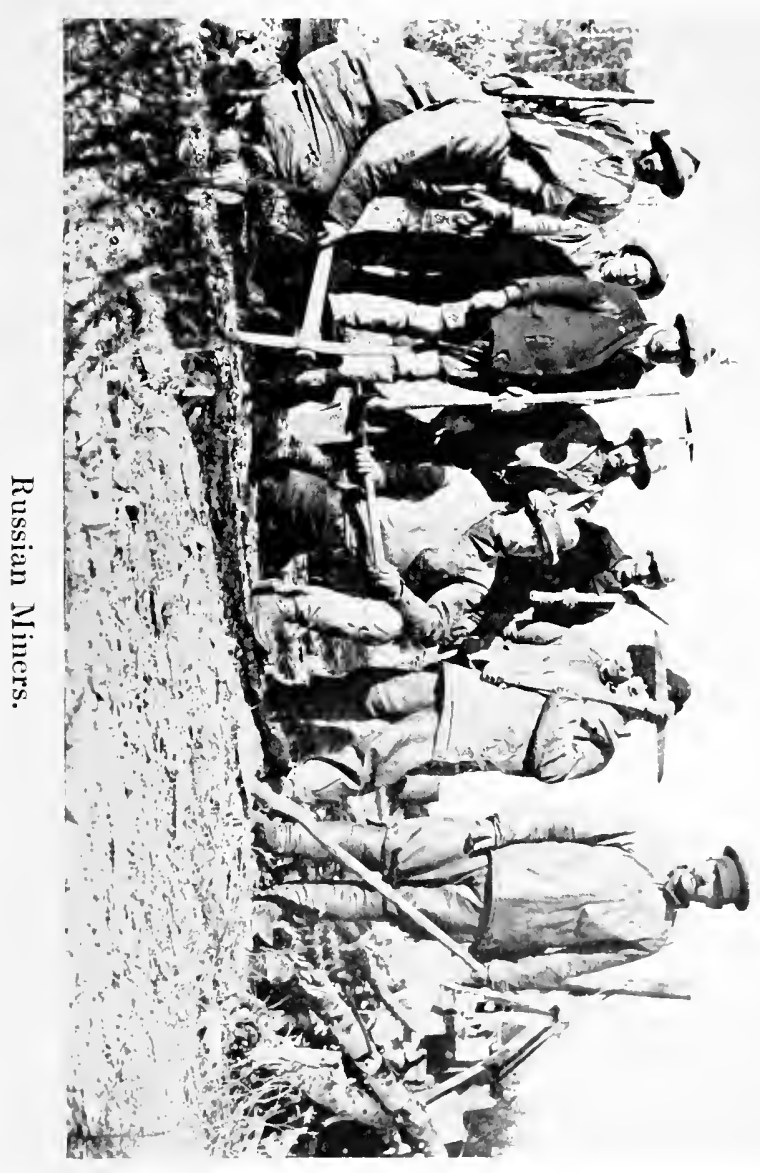



Any claims staked out before that time would be valid, according to Russian law. In order to present his papers before the Governor, the Count would have to wait till navigation opened up late in May, for the town of Anadyr lies far up the river of that name, and is ice-locked till well into the summer.

I received a cablegram to hurry out to Vladivostok, and make ready to start at an hour's notice. It was the intention of our company to charter a steamer for four months, and, with thirty Russian miners, steam with all speed toward the north, make a hasty examination of the beaches in question, and even though there might be American miners there (who would be without Government permission), we were to stake out claims and then hurry to Anadyr and file our papers before the Governor should have so much as heard of the existence of the Count. In all this we were well within the law, and, as our company had already spent a large sum of money in the work, it was but right to use every legal means to establish a claim to at least a portion of the field.

Through our agent at St. Petersburg we were kept informed of the movements of our rivals. Our agent in San Francisco was instructed to inform me, by cable, as to what steamer the Count chartered, her speed and equipment. Meanwhile 
I was busy looking up a vessel, and after great difficulty, secured the Russian steamer Progress, Captain Gunderson. I provisioned her for six months, filled her up with coal enough for five months' steaming, and by June 3 everything was ready. The previous day I had received a cablegram from San Francisco, stating that the rival expedition, under the management of Count Bogdanovitch and George D. Roberts, an American mining engineer, would sail from that port on June 6. Their speed was ten knots, and they would stop at Nome and one or two other United States ports. They were in no hurry, and were entirely in ignorance of our existence. Their boat was the Samoa, a Puget Sound lumber vessel. We could make eleven knots an hour, and had a slightly shorter route to follow than they. Furthermore, we knew, and they did not. We learned that at Plover Bay, on the Russian side, they were to meet a Russian gun-boat named the Yakut, which would help to drive away any American miners who might surreptitiously have opened up claims on the Siberian side. Of these rumor said that there were some three thousand.

At five o'clock in the afternoon of June $\mathbf{3}$ we turned our prow seaward, but, after going a hundred yards, a bolt gave way in the engine, and we had to lay up for repairs. I chafed at the enforced delay, but the next morning we were off. 
Before we had cleared the entrance of the long, winding bay, we ran into a heary fog-bank, and, after feeling our way along for a while, we were obliged to drop anchor again. When the fog lifted we found that we had passed within a hundred yards of a rocky promontory, and had escaped only by good luck. It was not till the next day that we reached the open sea, and six days later we were riding at anchor in the harbor of Petropaulovsk. At that point I put off four men to open up a copper vein that $I$ had located the first time I had passed that way. After having filled our water-tanks again, we pushed toward the north. In Bering Sea we found it still cold and foggy, but we kept the vessel up to her eleven knots, even at the risk of suddenly encountering ice. By keeping a sharp lookout and frequently taking the temperature of the water, we lessened the danger as much as possible.

Some of the Russian miners on board were set to work making a large United States flag, with which to decoy natives on board, for they can scarcely be induced to go on board a Russian ship, because of the rough treatment they frequently. receive. On June 14 the temperature of the water suddenly dropped from forty to thirtyfour degrees, which showed plainly that we were nearing ice. We slowed down, and half an hour later sighted an iceberg through the mist. 
As our vessel was of steel and without compartments, a very slight blow would put us hors de combat, so we took every precaution. 'There were but two life-boats for a crew of seventy men in all, many of whom would be likely to make trouble in case of accident. The ship's officers and I always had our revolvers handy for any emergency.

On the 16th we arrived off Cape Chaplain, or Indian Point, as the Americans usually call it. Between us and the shore there lay a band of ice at least thirty-five miles broad. We tried to discover an opening in it, but without success. We therefore headed for St. Lawrence Island, which lies near Bering Strait and belongs to Uncle Sam. As soon as we had cast anchor the natives came off to see us. The men were small but stocky, and looked much like North American Indians. Their women are rather good-looking, but are accustomed to tattoo as soon as they reach the age of womanhood. We found that about two thirds of the tribe were suffering either from the measles or the grippe. The mountains that loomed up in the background were used as burialplaces. The dead were laid there, exposed, and the dogs and wild animals soon disposed of them. The higher the rank of the dead man the higher he was placed on the mountain.

Dr. Lorego of the Presbyterian Mission came 


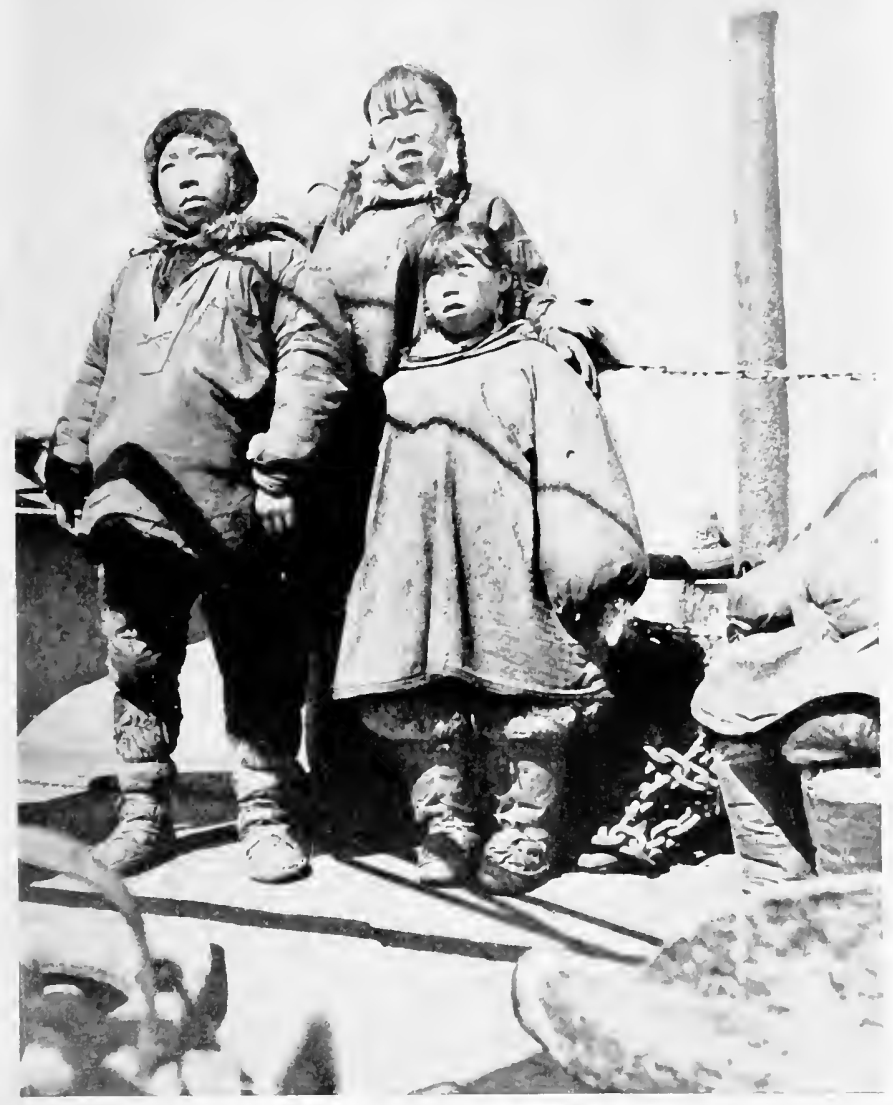

Picked it) on the Ice ofl St. Iawrence Island. 
off to see us, and courteously invited us ashore. It was an invitation that I gladly acepted. Through him I learned from the natives they were unaware that any American miners had landed on the Siberian side.

As we were about to weigh anchor and go in search of an opening in the ice by which we could reach the Asiatic shore, a steamer loomed up through the fog. She dropped anchor near us, and I found, to my delight, that slie was the exUnited States cutter Corwin, which, at that time, belonged to the Corwin 'Trading Company. On board were several American miners from Nome, who were bound for Indian Point, where they firmly believed gold was to be found. 'The captain of the Corvin kindly offered to guide us through the ice, and, if necessary, to lend us an ice pilot. I therefore contracted with him, for five hundred dollars, to eut a channel through the ice to Indian Point. We learned that there is always a narrow strip of water between the ice and the shore up and down the coast at that season. As the wind was rising I hurried back to my ressel and asked our eaptain to make ready to follow the Corrin, but within an hour a gale was raging, and the Corwin signaled us to follow her under the shelter of the island.

It was a beautiful sight to see Captain West of the Corwin handle his ressel as easily as though 
it were a rowboat on a lake. He had spent twenty years in the Arctic seas, and knew his business thoroughly. Before our anchor was fairly up he was steaming away before the gale a mile in advance. We followed him around the point of the island to a sheltered nook, and there dropped anchor to await the cessation of the storm.

The next morning the day broke fine and clear. Captain West affirmed that to see a perfect summer day one must go to the far north. The Corwin took the lead, and a five-mile run brought us to the edge of the ice-pack. There the Corwin slowed down, and we ran as close alongside as was safe. Captain West shouted through the megaphone, "Good-morning. I find the ice pretty heavy, but it is loose, and with care you will be able to follow us." He then sent to us Captain Coffin, an old-time whaling captain, whom he happened to have with him on the Corwin, to act as ice pilot for our boat. Captain Coffin has a record of over forty years in the north seas. As I was anxious to have the experience of smashing through the ice on an icebreaker, I went aboard the Corwin. The Progress followed about six lengths behind.

The Corwin has twelve feet of solid greenheart timber in her bows, four feet of the same on the sides, and two feet aft. She is barkentine 


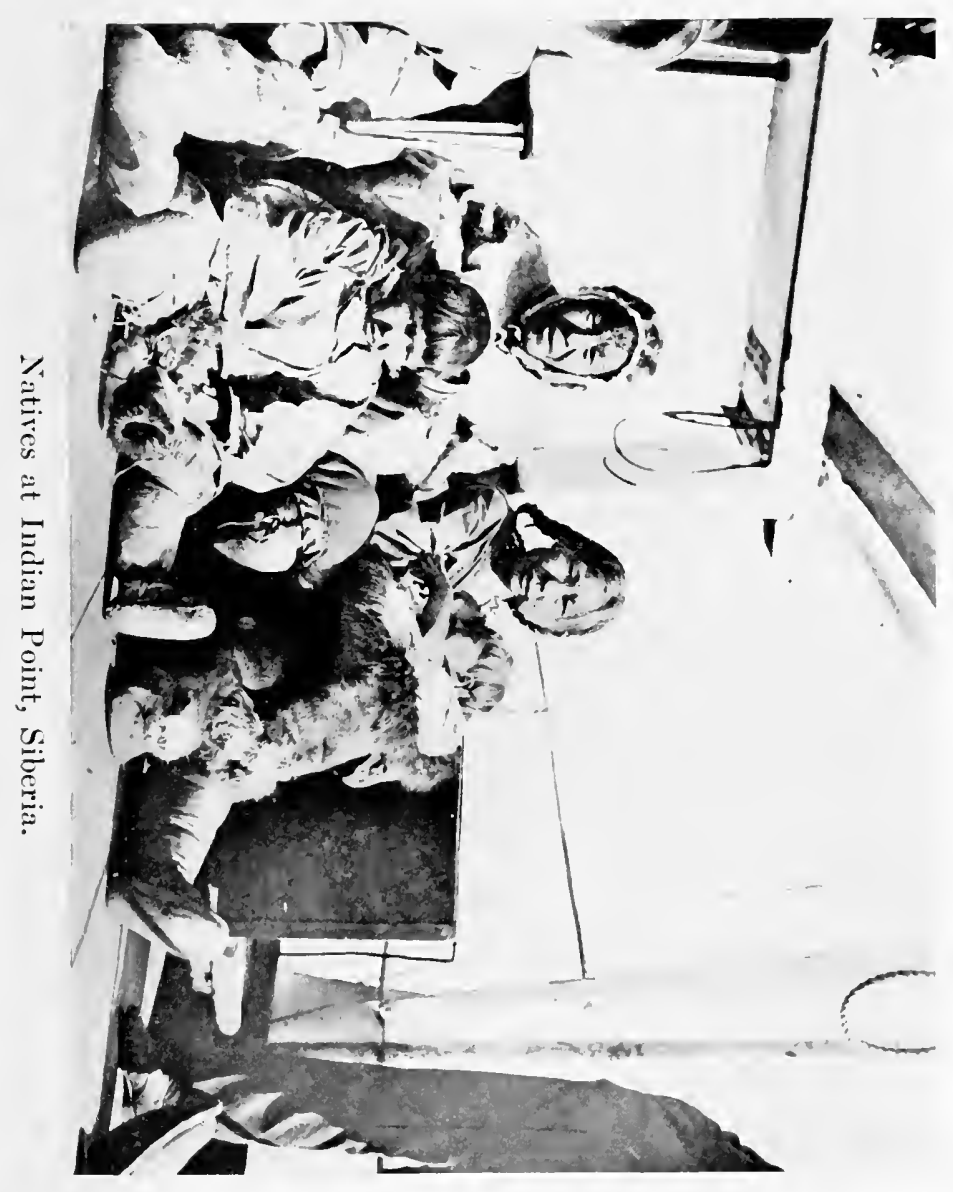



rigged, a hundred and twenty feet long, with a speed of nine knots. She is twenty-four years old, all but one of which have been spent in Arctic waters.

When all is ready Captain West mounts to the crow's-nest to con the ship, and Captain Forrest, another old whaler, is on the bridge. The wheel is in the hands of two intelligent Boston sailors. Captain West sings out, " One bell-starboardsteady!" and we are off. It looks as if it were going to be a ticklish business for the Progress, with only half an inch of steel to withstand the pressure of the loose bergs, but I say to myself that with Captain Coffin in the crow's-nest, and the Corwin in the lead, it is ten to one that she comes through without even knocking the paint off.

As we gather speed I hurry to the stern to see how the Progress is coming on. She winds her way beautifully between the bergs, in and out through the passage which we are making.

Some of the ice the Corwin can push to one side or the other, but when this is not possible she backs up in order to get good headway, and charges the obstruction, and strikes it fairly between the eyes. She comes to a dead stop, and quivers from stem to stern with the tremendous impact. A rending, grinding noise is heard, and the berg which challenged us is a berg no longer; 
and its fragments are brushed aside as we push our way through. Captain West laughingly calls from above, "Get out of the way, if you don't want to get hit." So on we go, backing and turning, and plunging and wriggling through the ice. As we were thus engaged I espied a seal, about three hundred yards off our starboard bow, and, seizing a Winchester, I let drive. The captain called down, "Killed; good shot." I should have done well to rest on my laurels, for though I had above forty more shots that day I did not kill anything.

By six o'clock we were through the ice and in open water again, with Indian Point, or Cape Chaplain, dead ahead. Almost immediately we were boarded by the natives, who called out:

" Hello, hello, how d' ye do?"

We answered in kind. Then, after a string of lurid oaths in bad English, they said:

"Plenty man cough-make die-you got medicine?" But to our question as to how many people there were in their village they replied:

"Don't know."

"Why, can't you count?"

"No; Siberia side all $d-n$ fools." At which we were forced to smile.

"Say, you got chaw tobacco?" I could not remain deaf to this appeal, so I cut up a cigar and watched it go into their mouths. Then, after I 


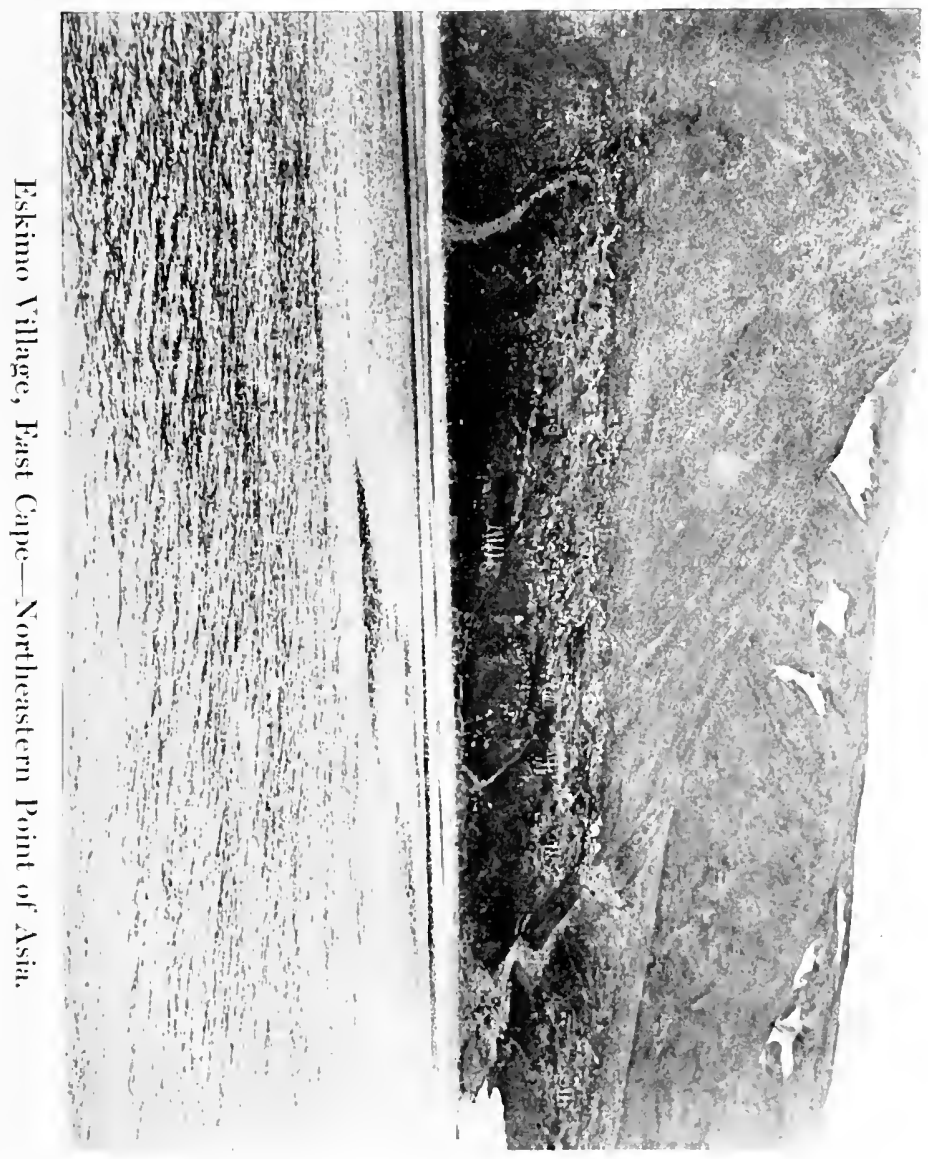




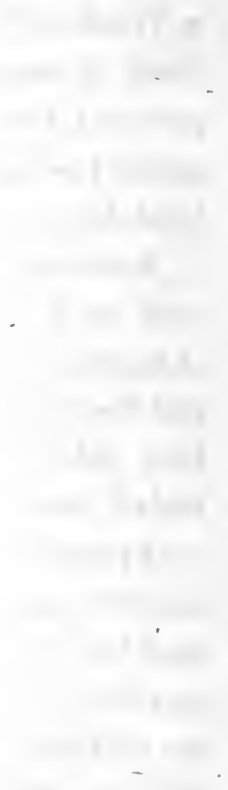


had taken their photograph in a group, we all went ashore, where I found a few native skin huts and one or two houses built with timber which they had obtained in trade from whalers. 'These were modeled after the houses that the whalers or missionaries had erected.

Indian Point is a long, low spit of land, and is a freak of nature, being nothing more nor less than a moraine in the sea. The great icebergs ground here and melt, dropping the stone and gravel which they have brought from some distant bay where they were born.

Kovarri, the old chief of the tribe, came aboard, and we interviewed him. He said there were no American miners on the Siberian side. We did not believe him implicitly, but found later that he had told the truth. We succeeded in hiring a noted native pilot to show us along the coast. He was named "Shoo Fly," and came of very mixed parentage. These natives were all large, strong, and hearty, and were good sailors, having had experience on many United States whalers, which recruit their crews among these men before going up into the Arctic Sea. 'These fellows are splendid oarsmen, and as good as Americans at chasing whales. They speak a little English, especially the bad words, and chew as much tobacco as they can lay their hands on, while as for drink, they are crazy for it. The natives just to the south of 
them are very different, for they have not come in contact with the whalers to so great an extent.

I shipped a boat's crew of these men, and steamed north to St. Lawrence Bay. In the steam-launch we explored every portion of the shore of this bay, but could find no trace of gold, although this was the very spot that Count Unarliarsky was depending upon to make the fortune of his company. Then we steamed north into Bering Strait. Here lie the two islands, “ Big Diomed " and " Little Diomed," one Russian and the other American. After prospecting in vain we returned to the mainland, and rounded East Cape, and found ourselves, for the first time, on the waters of the Arctic Ocean. We landed at a little village built on the steep slope of a high hill. It had just lost one half its population through measles and the grippe. Corpses were lying about, half eaten by the dogs. A little child had a leather thong tied through the eye-holes of a skull, and was dragging it about for a cart. The child's father said he did not know whose skull it was. After the dogs had gotten through with it how was he to tell! These people live in regular Eskimo huts, built of stone, in the shape of a half-sphere, and with a long tunnel for an entrance, through which they crawl on hands and knees.

Nothing could be more desolate than the pros- 
pect at this point. Behind the village was a bleak hill. The beach was only fifty feet wide, and before it lay the grim Arctic Sea. There was only one thing of beauty, and that was the skin boats of the natives, which were drawn up on the beach. They were shaped like an American whale-boat, and were capable of carrying forty men. In these they follow the ice-pack, and capture seals and walruses, and occasionally a whale. A few of the natives have secured bomb-guns from the whalers.

Whenever a whaling-vessel completes its cargo and is ready to turn toward home, it disposes of all its whale-boats to the natives, taking, in return, whalebone, ivory, and skins. A good boat will bring one thousand dollars' worth of such goods. The condition of these natives is pitiable in the extreme. Disease and filth are doing their work, and it is a wonder that any of them have survived as long as they have. The whalers sell them spirits at a small price, and, being utterly without self-control, they speedily become slaves to drink. The American Government makes no effort to stop this sort of thing, and the Russian Government can do but little to stop it with a single little gunboat.

We went as far north as the Arctic Circle, but, finding no gold in the beach sands nor in the floatrock in the rivers, we turned south again, and, 
after picking up some men whom we had left to finish prospecting St. Lawrence Bay, we continued south, examining the coast as we went. We looked into Plover Bay, with the expectation of finding the Samoa there; and not seeing her we steamed out, and, with the aid of the launch and the native boat crews, examined the southern part of the Tchuktche peninsula. There were splendid deposits of steaming-coal, but the general geologic formation made it plain that there was no gold to be found.

Once more we steamed into Plover Bay, but the Samoa had not yet arrived, and we determined to wait for her. Two days were spent in the pleasant occupation of hunting eider-duck and making a short trip into the interior. On the third day we heard, through the fog, the sound of a siren whistle. Of course we answered, and an hour later the Samoa came nosing through the fog and picking her way through the light drift-ice. As soon as her anchor was down I went aboard. As I went up the gangway I saw half a dozen Russians and as many Americans standing in a group on the deck. I walked up to them, but before I had time to introduce myself Count Bogdanovitch said:

"Captain, I am glad to see you. You have some coal for us, I believe?"

"No; I have not any for you," I said, smiling. 


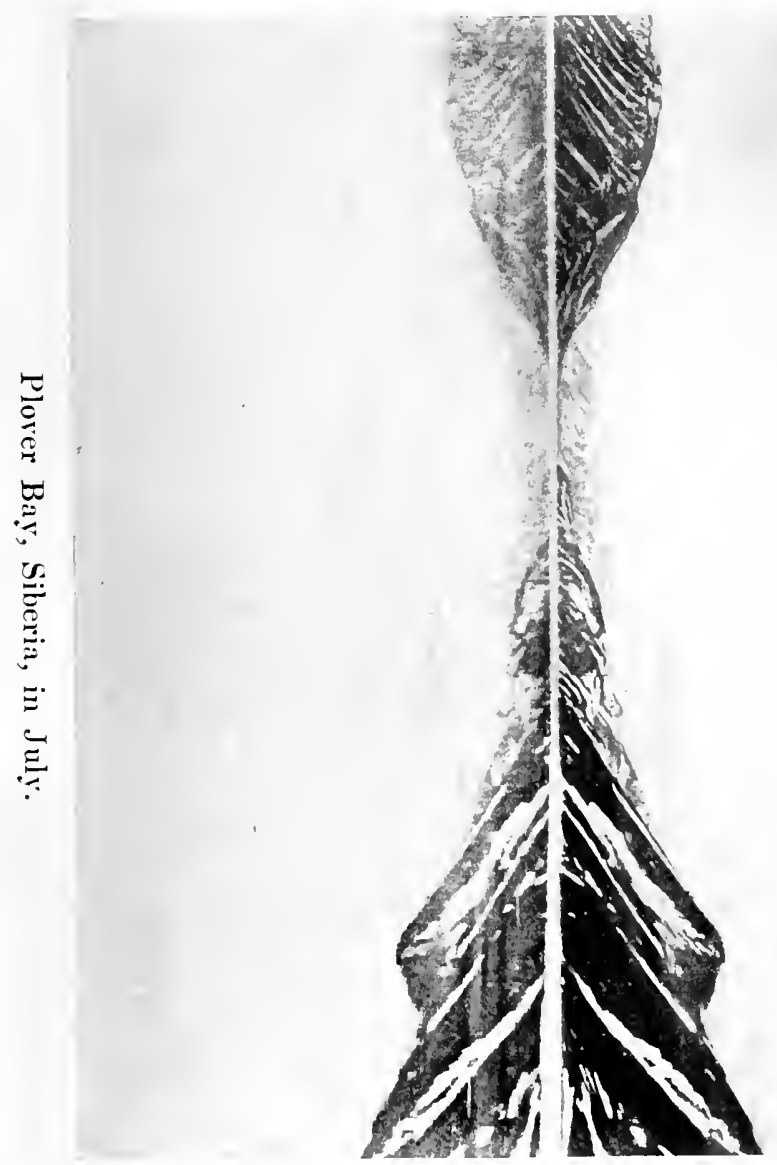


, 
"Oh, you are a steam-whaler," and his face fèll.

" No, not a whaler," I said.

"Well, then, what are you here for?" he asked, curiously.

"I am on the same errand as you."

As soon as he comprehended he was terribly angry, and apparently wished me at the bottom of the sea. He turned on his heel and walked away, without doing me the courtesy of asking me into the cabin, although it was raining. But one of the Americans stepped forward, and I was taken to their quarters, where explanations followed. I told them the situation, how that we had carefully prospected all along the coast, but had found no gold. I felt I was doing them a favor to let them know that there was no use in spending time and money in a search for gold along the Siberian coast of Bering Sea. Whether or not they believed me I cannot tell, but the next morning we weighed anchor, and left them there waiting for the arrival of the Yakut.

The search for a Siberian Klondike was over. 
University of California

SOUTHERN REGIONAL LIBRARY FACILITY

305 De Nevi Drive - Parking Lot 17 - Box 951388

LOS ANGELES, CALIFORNIA 90095-1388

Return this material to the library from which it was borrowed. 
UC SOUTHERN REGIONAL LIBRARY FACILITY

AA $000276474 \quad 4$ 


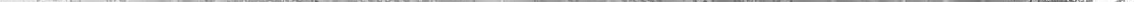

